UNIVERSIDADE DE SÃO PAULO

INSTITUTO DE GEOCIÊNCIAS

\title{
MODELO CONCEITUAL DO AQUÍFERO FRATURADO DE UMA ÁREA INDUSTRIAL EM BARRA MANSA, RJ
}

\section{FÁBIO SARTORIO}

Tese apresentada ao Programa de Pós-Graduação em Recursos Minerais e Hidrogeologia para obtenção do título de Mestre em Ciências

Área de concentração: Hidrogeologia e Meio Ambiente

Orientador: Prof. Dr. Reginaldo Antonio Bertolo 
Autorizo a reprodução e divulgação total ou parcial deste trabalho, por qualquer meio convencional ou eletrônico, para fins de estudo e pesquisa, desde que citada a fonte.

Serviço de Biblioteca e Documentação do IGc/USP

Ficha catalográfica gerada automaticamente com dados fornecidos pelo(a) autor(a) via programa desenvolvido pela

Seção Técnica de Informática do ICMC/USP

Bibliotecários responsáveis pela estrutura de catalogação da publicação: Sonia Regina Yole Guerra - CRB-8/4208 |

Anderson de Santana - CRB-8/6658

Sartorio, Fábio

Modelo conceitual do aquífero fraturado de uma área industrial em Barra Mansa, RJ. / Fábio Sartorio; orientador Reginaldo Antonio Bertolo. -- São Paulo, 2019. $86 \mathrm{p}$.

Dissertação (Mestrado - Programa de Pós-Graduação em Recursos Minerais e Hidrogeologia) -- Instituto de Geociências, Universidade de São Paulo, 2019.

1. Hidrogeologia. 2. Aquífero fraturado. I. Bertolo, Reginaldo Antonio, orient. II. Título. 


\section{UNIVERSIDADE DE SÃO PAULO \\ INSTITUTO DE GEOCIÊNCIAS}

\section{MODELO CONCEITUAL DO AQUÍFERO FRATURADO DE UMA ÁREA INDUSTRIAL EM BARRA MANSA, RJ}

\section{FABIO SARTORIO}

Orientador: Prof. Dr. Reginaldo Antonio Bertolo

Dissertação de Mestrado

№ 837

COMISSÃO JULGADORA

Dr. Reginaldo Antonio Bertolo

Dra. Mirna Aparecida Neves

Dr. Renato Luiz Prado

SÃO PAULO

2019 


\section{RESUMO}

Sartorio, F. (2019). Modelo conceitual do aquífero fraturado de uma área industrial em Barra Mansa, RJ. Dissertação (Mestrado). Instituto de Geociências, Universidade de São Paulo, São Paulo.

O conhecimento sobre aquíferos fraturados ainda é muito limitado no Brasil, a maior dificuldade no desenvolvimento de novos trabalhos deve-se a grande complexidade no estudo desse tipo de aquífero, que apresenta altas heterogeneidade e anisotropia. Apesar do desenvolvimento de algumas pesquisas na última década, o atual cenário de estudos hidrogeológicos e ambientais carece de metodologias especializadas, que possam ser amplamente empregadas. Visando à expansão do conhecimento no campo hidrogeológico de meios fraturados, esta dissertação conduziu as etapas iniciais de investigação do aquífero fraturado em uma área industrial contaminada. Foram aplicados métodos não invasivos em escalas de investigação regional e de detalhe. As etapas de trabalho realizadas foram (1) a análise de lineamentos, traçados a partir de modelos digitais de elevação (MDEs), para observação dos principais trends estruturais da área de estudo; (2) Levantamento estrutural em afloramentos pelo método de scanlines, principal atividade desse estudo, com amostragem sistemática de dados de fraturas, e posterior tratamento e interpretação dos dados; (3) Levantamentos geofísicos pelos métodos de caminhamento elétrico e sísmica de refração para mapeamento local do topo rochoso e identificação de descontinuidades e estruturas em subsuperfície; (4) Correlação dos dados obtidos nas diferentes etapas e associação dos dados aos eventos tectônicos mais recentes descritos na literatura, inferindo quais grupos de fraturas apresentam maior propensão à atividade hidráulica. Foram identificados dois trends estruturais principais de lineamentos, de direções NW-SE, com lineamentos mais numerosos e curtos, e NE-SW, com lineamentos mais longos, cortando os lineamentos NW-SE. A amostragem estrutural identificou três grupos de fraturas: (1) fraturas de mergulho de baixo ângulo, de atitudes dispersas, com indícios de campo para fluxo de água; (2) fraturas NW-SE, de alto ângulo de mergulho, possivelmente mais ativas hidraulicamente por reativação pelo evento neotectônicomais intenso, de transcorrência dextral E-W; (3) fraturas ENE-WSW, de alto ângulo de mergulho, possivelmente mais ativas hidraulicamente por reativação pelo evento neotectônico mais recente, distensão NW-SE. Na escala de maior detalhe, as estruturas observadas nos perfis geofísicos apresentaram ótima correlação com os lineamentos traçados sobre o sítio industrial, o que possibilitou a inferência das áreas com maior potencial para fluxo de água no aquífero fraturado local.

Palavras-chave: hidrogeologia, aquífero fraturado, scanline. 


\begin{abstract}
The knowledge on fractured aquifers is still very limited in Brazil, the biggest difficult in the development of new works relays on the great complexity of this kind of aquifer, that presents high heterogeneity and anisotropy. In spite of some research in the past decades, the present scenario on environmental and hydrogeological researches lacks specialized methodologies with large applicability. Seeking the expansion of knowledge in the fractured aquifer's field, this project conducted the initial steps for the fractured aquifer's investigation on a contaminated industrial site. Noninvasive methods applied in regional and local scales were: (1) lineament analysis, tracing lineaments over digital elevation models (DEMs), in order to observe regional structural trends for the studied area; (2) structural survey in outcrops using the scanline method, systematically sampling data from joints, and then treating and interpreting the data; (3) geophysical survey with electroresistivity and seismic methods for underground mapping and location of structures and discontinuities; (4) data correlation for the different steps and association with recent tectonic events described in literature, concluding which joint groups present higher tendency for hydraulic activity. There were identified two structural trends of lineaments, oriented NW-SE, with more numerous and shorter lineaments, and NE-SW, with longer lineaments, that cut the NW-SE lineaments. The structural survey in outcrops identified three joint groups: (1) low angle joints, with disperse attitudes, that show field indications for water flux; (2) high angle joints oriented NW-SE, likely with high hydraulic activity due to the reactivation by the intense dextral transcurrent tectonic event; (3) high angle joints oriented ENE-WSW, likely with high hydraulic activity due to the reactivation by the most recent tectonic event, a NW-SE distension. In a scale of detail, the geophysical methods presented great correlation with the lineaments traced over the industrial site, what made possible determine the areas with higher potential for underwater flux in the local fractured aquifer.
\end{abstract}

Key-words: hydrogeology, fractured aquifer, scanline 


\section{SUMÁRIO}

1. INTRODUÇÃO

2. OBJETIVOS

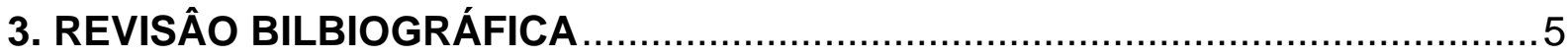

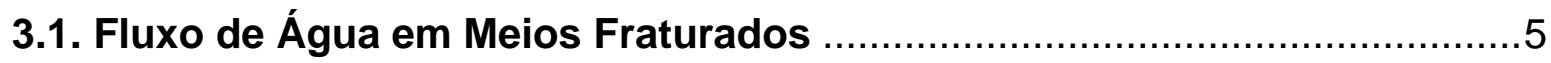

3.1.1. Tectônica e padrões de fraturamento ....................................................

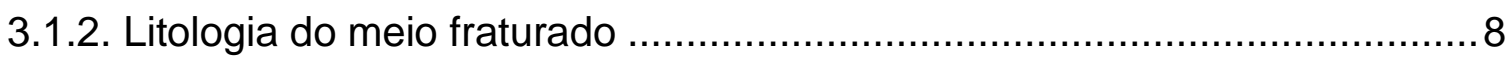

3.1.3. Quantificação do fluxo em meios fraturados .........................................

3.2. Métodos de Investigação Estrutural de Aquíferos Fraturados ................10

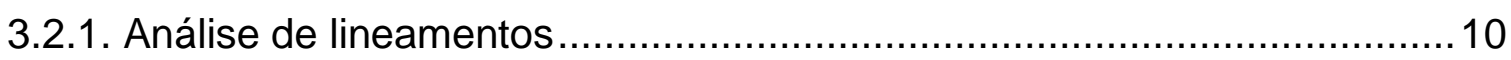

3.2.2. Levantamento estrutural em afloramentos.............................................11

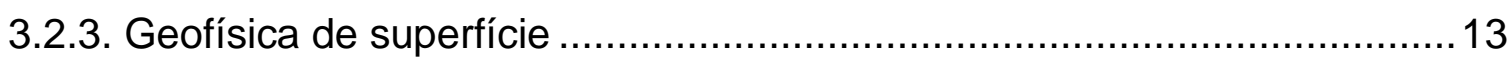

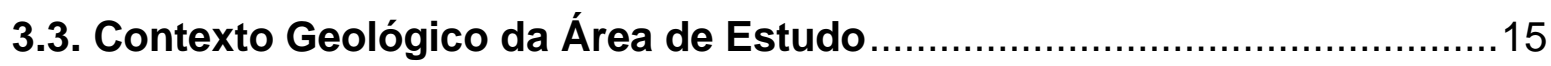

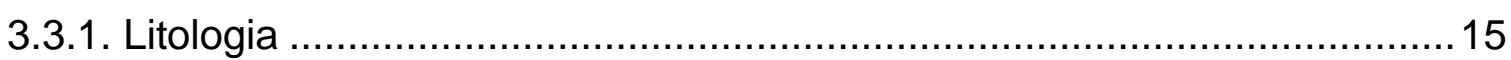

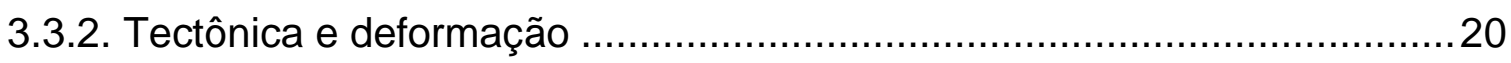

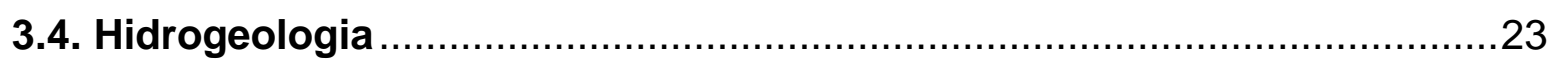

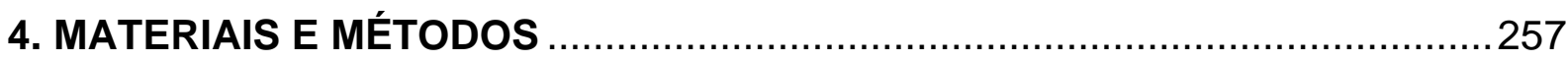

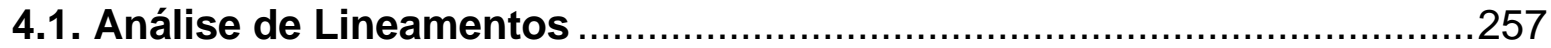

4.2. Levantamento Estrutural em Afloramentos.......................................269

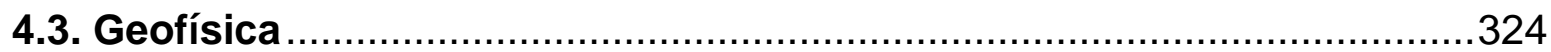

4.3.1. Eletrorresistividade - caminhamento elétrico …......................................324

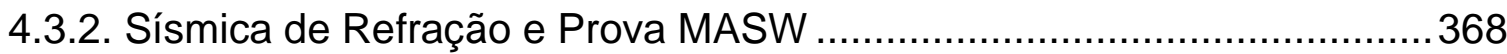

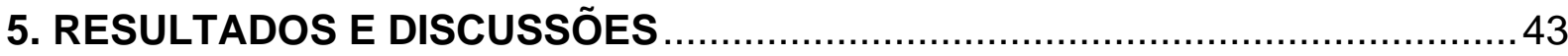

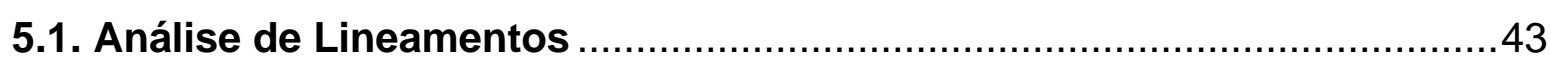

5.2. Levantamento Estrutural em Afloramentos.............................................. 45

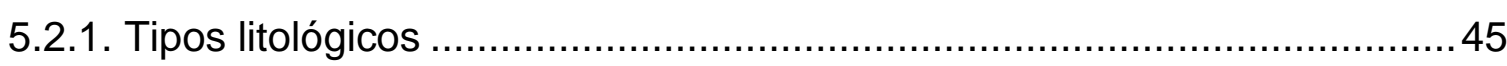

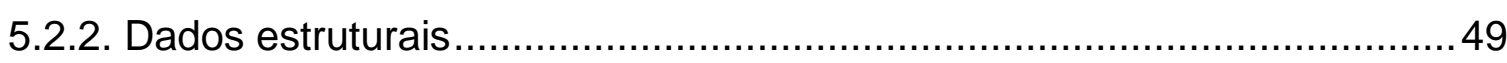

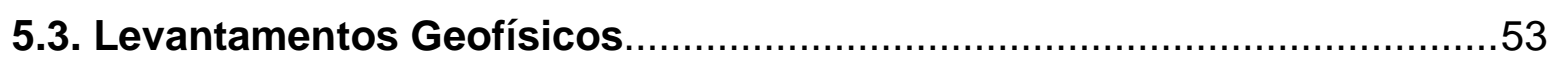

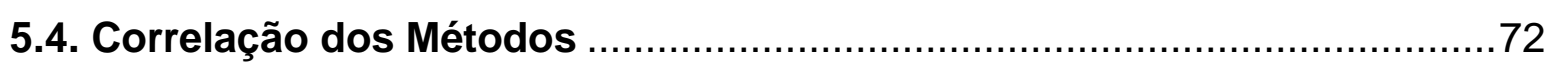

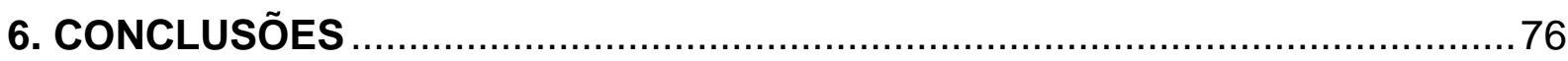

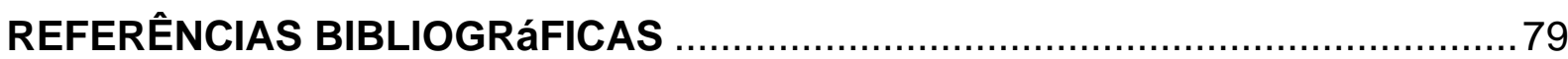




\section{LISTA DE FIGURAS}

Figura 1: Localização da área de estudo, com detalhe à pedreira e ao sítio industrial, e zoom e destaque às áreas contaminadas do sítio industrial (modificado do Google Earth)..

Erro! Indicador não definido.

Figura 2: Regimes extensional (i), compressivo (ii) e transcorrente (iii). Fraturas extensionais em linhas tracejadas e fraturas de cisalhamento em linhas contínuas (modificado de Vialon et al., 1976).

Figura 3: Exemplificação do viés de orientação. Espaçamento d', observado no afloramento, é muito maior que o espaçamento $d$ real entre as fraturas, devido ao baixo ângulo $\alpha$ de incidência das fraturas na face observada (modificado de Terzaghi, 1965).

Figura 4: Mapa geológico simplificado do segmento central da Faixa Ribeira na região das bacias de Resende e Volta Redonda(modificado de Heilbron et al., 2004, por Negrão, 2014)..

Figura 5: Mapa de lineamentos da Bacia de Resende, com subdivisão em compartimentos de A a E (Albuquerque, 2001).

Figura 6: Exemplo de MDEs com diferentes direções de incidência de luz: A - 315 (noroeste) e B $-45^{\circ}$ (nordeste).

Figura 7: Esquema de amostragem por scanline para um afloramento de 80 metros. Apenas as fraturas (pretas) que interceptam a scanline (azul) são amostradas (modificado de Pino, 2012).

Figura 8: Tabela guia para determinação do Coeficiente de Rugosidade de Junta (JRC, Barton e Choubey, 1977).

Figura 9: Determinação do peso '1/sem a', sendo: d' - espaçamento aparente; $d$ espaçamento real; $\alpha$ - ângulo de intersecção; $L$ - comprimento observado; N90 número corrigido de fraturas (Terzaghi, 1965, em Fiume, 2013).

Figura 10: Eletrodos cravado no chão, conectado ao equipamento SYSCAL Pro por meio de garra jacaré e cabo multifilar.

Figura 11: Configuração de posicionamento dipolo-dipolo. Diferentes níveis (n1, n2, n3...) são medidos para diferentes combinações $A B / M N$. Para o avanço horizontal das medidas, há a comutação de eletrodos no sentido do caminhamento, realizada automaticamente pelo equipamento (Braga, 2006).

Figura 12 Localização dos perfis de caminhamento elétrico, com amplificação das áreas de detalhe (A, B e C; modificado do Google Earth).

Figura 13: Localização dos perfis sísmicos. Perfis DA e DC (violeta) correspondem à sísmica de refração e perfis LL1, LL2 e LB (amarelo) correspondem à prova MASW (modificado de EEG, 2017). 
Figura 14: Sismógrafo ABM BR-24; cabos sísmicos multipolares de alto isolamento

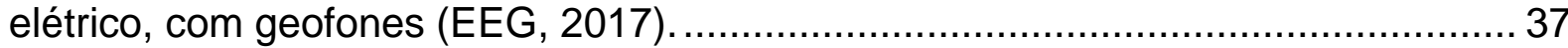

Figura 15: Configuração dos pontos de disparo para o perfil de sísmica de refração

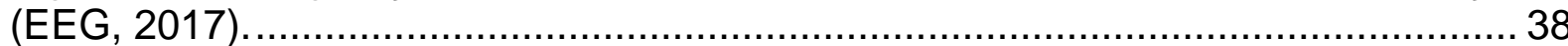

Figura 16: Configuração para execução da técnica de arraste, empregada nos perfis LL1 e LL2 (modificado de EEG, 2017)............................................................... 39

Figura 17: Mapa de lineamentos regional com diagrama de roseta, representativo da frequência de orientação e comprimento dos lineamentos. 44

Figura 18: Ampliação do mapa de lineamentos com foco no sítio industrial, base

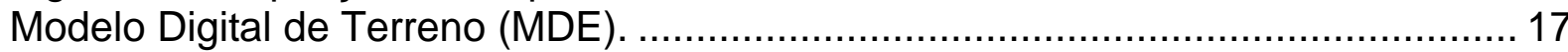

Figura 19: Ampliação do mapa de lineamentos com foco no sítio industrial, base

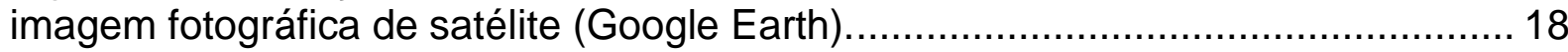

Figura 20: Localização espacial entre pedreira, ponto E e sítio industrial. ............... 45

Figura 21: Porção visualmente representativa da rocha observada na pedreira, com martelo para escala no canto inferior esquerdo.

Figura 22: Detalhe de fraturas preenchidas por veios de quartzo, recobertos por cristais formados por hidrotermalismo (A) e oxidação (B).................................... 47

Figura 23: Exemplo de afloramento encontrado na unidade industrial.

Figura 24: Localização das scanlines na pedreira (esquerda) e em local adjacente à

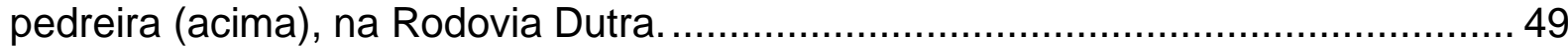

Figura 25: Estereograma representativo dos polos das fraturas amostradas na pedreira e no ponto E, totalizando 179 estruturas. Detalhes (1) de estereograma menor, representando os dados sem correção de Terzaghi (1965) e (2) de grupos de fraturas subverticais, associados por cor aos grupos de lineamentos espacialmente correlacionados.

Figura 26: Estereograma representativo dos polos das fraturas amostradas nos seis pontos aflorantes da unidade industrial, com detalhe de grupos de fraturas subverticais, associados por cor aos grupos de lineamentos espacialmente correlacionados.

Figura 27: Quadro comparativo com os três grupos de fraturas observados na pedreira e ponto $\mathrm{E}$.

Figura 28: Bloco diagrama com o modelo conceitual de disposição espacial dos três grupos de fraturas identificados para a Pedreira (a partir da análise de lineamentos e da amostragem estrutural por scanlines) Erro! Indicador não definido.

Figura 29: Mapa do sítio industrial com localização dos perfis de caminhamento elétrico e dos lineamentos traçados. 54 
Figura 30: Resultados de sísmica de prova MASW e resistividade por caminhamento

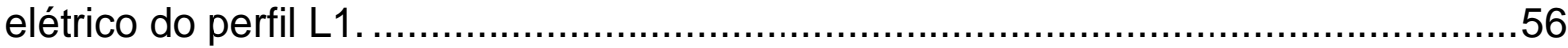

Figura 31: Resultados de sísmica de prova MASW e resistividade por caminhamento

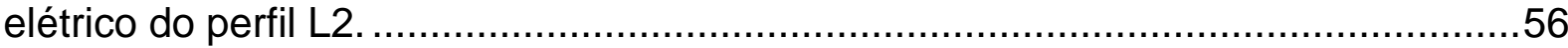

Figura 32: Resultados de resistividade do perfil M1 de caminhamento elétrico........60

Figura 33: Resultados de resistividade do perfil M2 de caminhamento elétrico.......61

Figura 34: Resultados de resistividade do perfil M3 de caminhamento elétrico.......62

Figura 35: Perfis A1 de caminhamento elétrico e sísmica de refração da Área A....63

Figura 36: Perfis A2 de caminhamento elétrico e sísmica de refração da Área A....63

Figura 37: Perfis A3 de caminhamento elétrico e sísmica de refração da Área A....64

Figura 38: Seção horizontal da área $A$ entre 9 e $11 \mathrm{~m}$, interpoladas a partir dos perfis de caminhamento elétrico A1 a A3.......................................................................65

Figura 39: Perfis B1 de caminhamento elétrico e sísmica de refração da Área B.....66 Figura 40: Perfis B2 de caminhamento elétrico e sísmica de refração da Área B....66 Figura 41: Perfis B3 de caminhamento elétrico e sísmica de refração da Área B....67 Figura 42: Seção horizontal da área B entre 9 e $11 \mathrm{~m}$, interpoladas a partir dos perfis de caminhamento elétrico B1 a B3. 68

Figura 43: Perfis C1 de caminhamento elétrico e sísmica de refração da Área C. ...69 Figura 44: Perfis C2 de caminhamento elétrico e sísmica de refração da Área C. ...69 Figura 45: Perfis C3 de caminhamento elétrico e sísmica de refração da Área C. ...70 Figura 46: Perfis C4 de caminhamento elétrico e sísmica de refração da Área C. ...70 Figura 47: Perfis C5 de caminhamento elétrico e sísmica de refração da Área C. ...71 Figura 48: Seção horizontal da área $C$ entre 9 e 12 m, interpoladas a partir dos perfis de caminhamento elétrico C1 a C5. .72

Figura 49: Comparação das direções de lineamentos identificadas com as direções das principais grupos de fraturas medidas nos afloramentos. 73

Figura 50: Mapa do sítio industrial com detalhe às zonas contaminadas e às estruturas observadas nessas áreas pelo método de caminhamento elétrico. 75 


\section{INTRODUÇÃO}

Aquíferos fraturados, também denominados como aquíferos cristalinos, são formados por rochas de porosidade primária muito baixa, a exemplo de granitos e gnaisses, nas quais o armazenamento e a transmissão da água ocorrem por meio das fraturas. Nas rochas, a rede de fraturas tem uma configuração complexa, de distribuição muito heterogênea, o que lhe confere altas heterogeneidade e anisotropia em relação ao fluxo de água.

Devido ao contexto geológico e geográfico observados em diversas regiões do país, é comum a existência de áreas industriais sobre terrenos cristalinos fraturados. A presença de industrias, principalmente as que estão em atividade desde o século passado, em diversos casos está associada à contaminação do substrato rochoso e do aquífero. Esse cenário resulta em um problema de natureza complexa, pois a complexidade no estudo do meio fraturado implica em grande dificuldade na resposta de problemas básicos de investigação ambiental, como determinação dos caminhos preferenciais do fluxo e volume e velocidade de transmissão da água.

No caso dos aquíferos fraturados, a resposta para esses problemas depende da boa investigação estrutural, para determinar a configuração geométrica da rede de fraturas, os grupos de fraturas presentes, as cargas hidráulicas e transmissividades, entre outros dados que possibilitem o melhor entendimento do fluxo de água. Entretanto, os estudos hidrogeológicos de aquíferos fraturados são uma área recente no Brasil, com relativamente poucas publicações na esfera acadêmica.

Este trabalho tem o propósito de contribuir para a expansão do conhecimento no campo da hidrogeologia de meios fraturados no Brasil, e para isso apresenta as metodologias utilizadas na etapa inicial de investigação de um aquífero fraturado que localiza-se em uma área industrial contaminada. Ao estudar um aquífero fraturado, a primeira etapa de investigação consiste em realizar um estudo de geologia estrutural de superfície, compreendendo como se deu a formação e qual a atual configuração das descontinuidades observadas na rocha formadora do aquífero.

A unidade industrial em que foi realizado este estudo localiza-se a poucos quilômetros a noroeste do município de Barra Mansa (RJ), à margem direita do Rio Paraíba do Sul. As investigações ambientais realizadas até o momento detectaram a 
presença de compostos orgânicos voláteis clorados (CVOCs) em concentrações superiores aos valores de referência de qualidade ambiental. Devido às características físico-químicas desses compostos, que apresentam baixa solubilidade e densidade superior à da água, existe a possibilidade da migração vertical descendente, o que justifica a necessidade de investigação do aquífero fraturado.

A região estudada localiza-se na porção sudeste do estado do Rio de Janeiro (Figura 1), no médio vale do Rio Paraíba do Sul, abrangendo os municípios de Resende, Porto Real, Quatis, Barra Mansa e Volta Redonda. O sítio industrial e a pedreira, localidades onde aconteceram as etapas de campo, ficam à margem direita do Rio Paraíba do Sul, na Rodovia Presidente Dutra (Erro! Fonte de referência não encontrada.). Dentro do sítio industrial há três áreas contaminadas, nas quais foram encontrados indícios de contaminação do substrato rochoso, decorrente da operação do sítio industrial ao longo das décadas. 

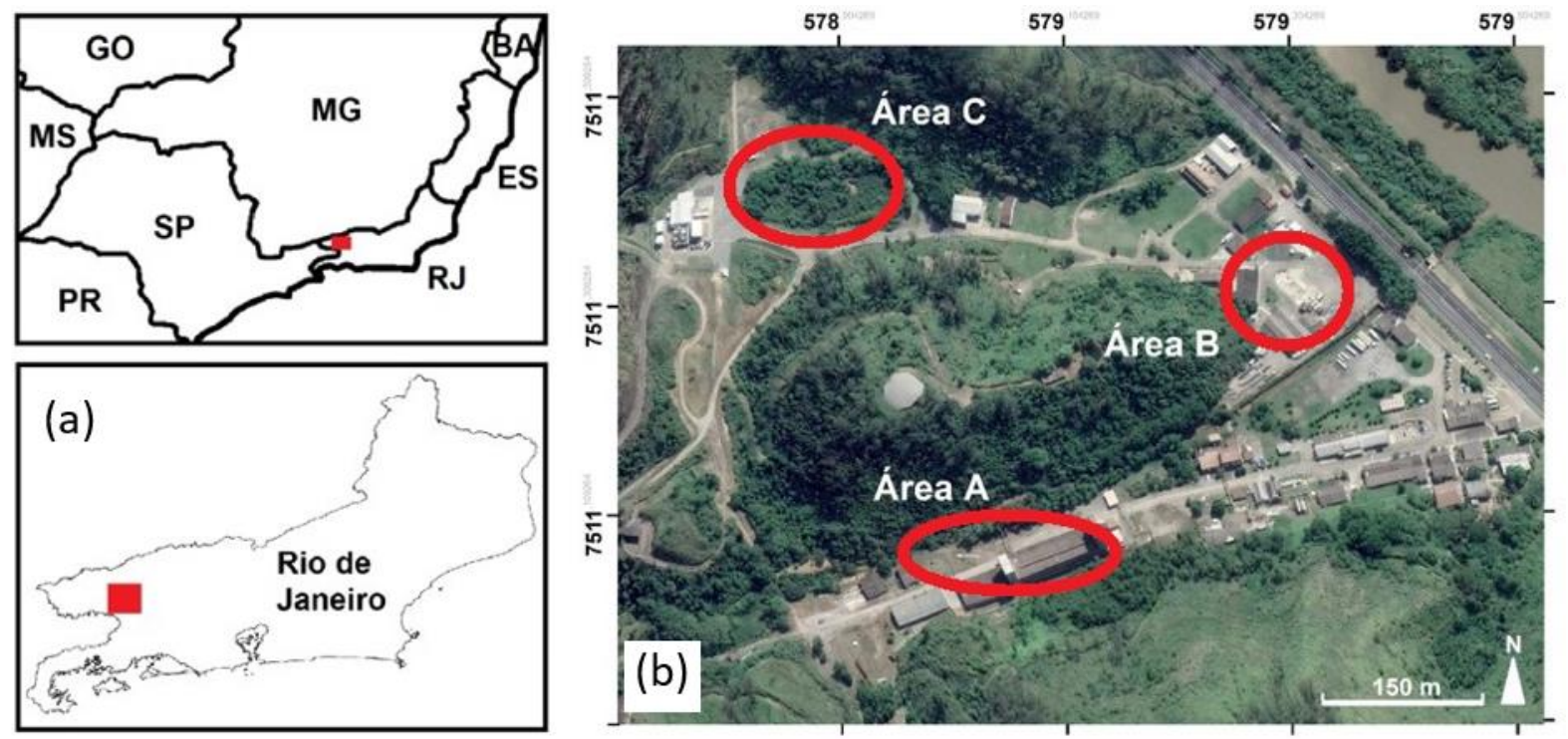

577

579

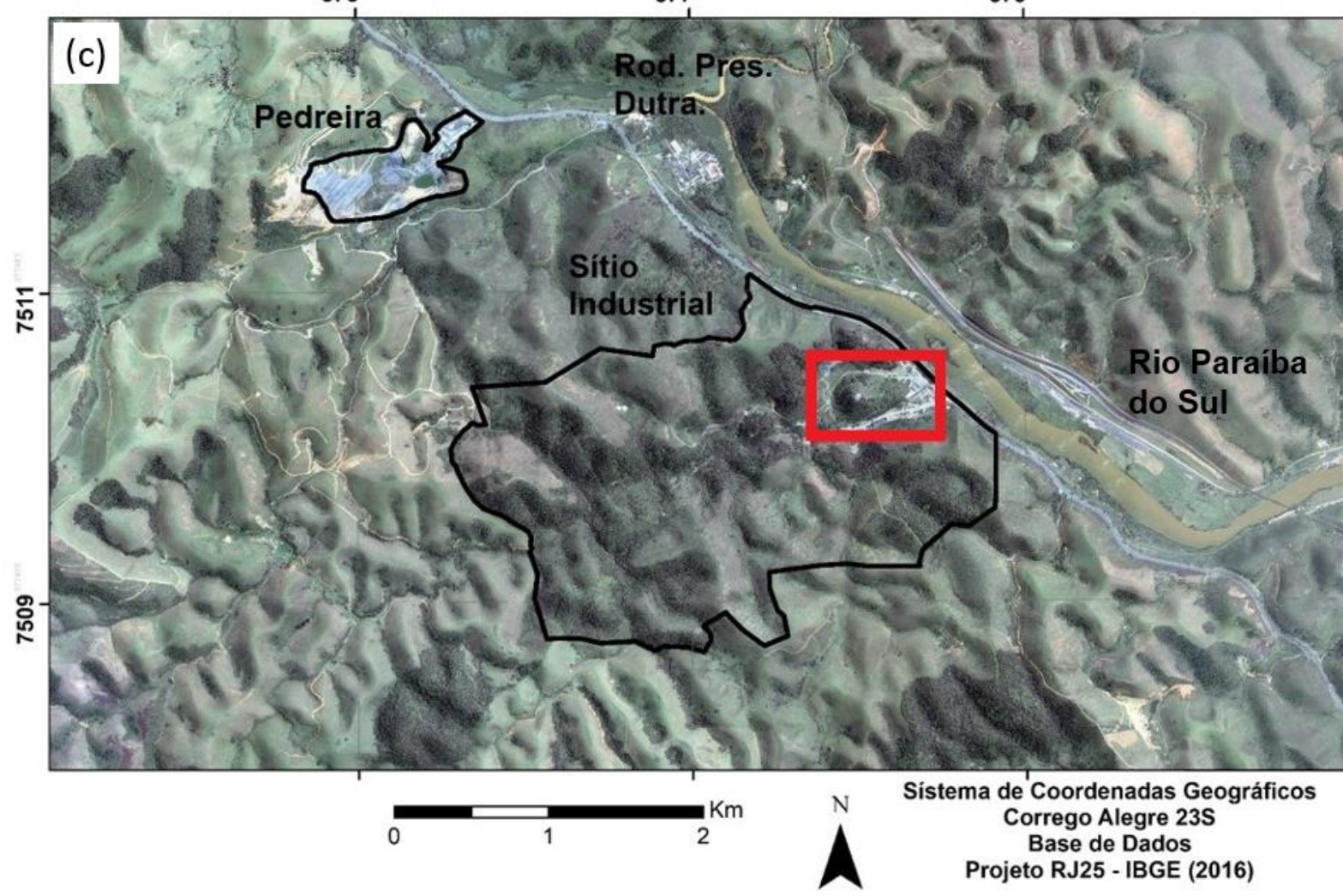

Figura 1: Localização da área de estudo (a), com detalhe à pedreira e ao sítio industrial (c), e zoom e destaque às áreas contaminadas do sítio industrial (b) (modificado do Google Earth). 


\section{OBJETIVOS}

O objetivo geral deste trabalho é a caracterização estrutural do aquífero fraturado na região de Barra Mansa, a oeste do estado do Rio de Janeiro, com ênfase na área delimitada pelo sítio industrial estudado. Para isso foram determinados quais grupos de fraturas estão presentes na região e quais desses grupos contribuem de maneira mais significativa para o fluxo de água em subsuperfície e, consequentemente, para o possível transporte de contaminantes. Os objetivos específicos foram:

- Análise de lineamentos, traçados a partir de modelos digitais de elevação (MDEs), para observação dos principais trends estruturais da região de estudo;

- Levantamento estrutural em afloramentos pelo método de scanlines, com amostragem sistemática de dados de fraturas relevantes para o estudo do aquífero fraturado (orientação, alteração, preenchimento, presença de água etc), com subsequente correção e interpretação dos dados estruturais;

- Levantamentos geofísicos pelos métodos de caminhamento elétrico e sísmica, dentro dos limites do sítio industrial, para mapeamento local do topo rochoso e identificação de descontinuidades e estruturas em subsuperfície;

- Correlação dos dados obtidos nas diferentes etapas e associação dos dados aos eventos tectônicos mais recentes descritos na literatura, inferindo quais grupos de fraturas apresentam maior propensão à atividade hidráulica. 


\section{REVISÃO BILBIOGRÁFICA}

Aquíferos cristalinos, comumente denominados aquíferos fraturados, são formados por rochas de porosidade primária muito baixa, nas quais o armazenamento e a transmissão de água ocorrem por meio das fraturas (porosidade secundária). O objetivo comum aos estudos desse meio geológico é a determinação dos caminhos preferenciais da água subterrânea, especialmente em casos de áreas contaminadas, nos quais esses caminhos também condicionam a dispersão de contaminantes.

A alta complexidade no estudo dos meios fraturados deve-se à complexa rede de fraturas, que thes conferem altas heterogeneidade e anisotropia. Dessa forma, o entendimento do fluxo nos aquíferos fraturados tem forte dependência do conhecimento do modelo da rede de fraturas e suas transmissividades. É clara, portanto, a importância da etapa de caracterização estrutural do aquífero para o desenvolvimento de modelos hidrogeológicos (Francese et al., 2009), auxiliando no gerenciamento de áreas contaminadas e na gestão de recursos hídricos.

\subsection{Fluxo de Água em Meios Fraturados}

O fluxo de água em meios fraturados se dá por meio das descontinuidades presentes no pacote rochoso, e segundo Domenico e Schwartz (1990), o fluxo em meio fraturado seria condicionado por três parâmetros geométricos: conectividade, densidade e abertura das fraturas. Entretanto, somente esses fatores não possibilitam uma caracterização suficientemente aproximada do cenário real de fluxo. A questão da escala de observação, por exemplo, aparece como fator condicionante de parâmetros como densidade e conectividade de fraturas, bem como da natureza de junções e da distribuição de comprimentos de fraturas (Odling, 1997).

Como destacado por Fernandes (2008), outras características são igualmente importantes na determinação dos principais condutos subterrâneos de água, como natureza das fraturas (extensional ou cisalhante), rugosidade, direção e mergulho, comprimento, ondulação, preenchimento e indicadores cinemáticos (Rouleau \& Gale, 1985). Para melhor compreender como se dá o fluxo de água, é necessário primeiramente entender os fatores que condicionam a existência das descontinuidades e, subsequentemente, quantificar de fato a sua capacidade de transmissão. 


\subsubsection{Tectônica e padrões de fraturamento}

As descontinuidades presentes nos pacotes rochosos são geradas por eventos tectônicos que, por não afetarem homogeneamente o terreno em escala regional, manifestam-se em domínios tectônicos (Fernandes, 1997). Domínios tectônicos são áreas com relativa homogeneidade em relação ao fraturamento e à reativação de fraturas por eventos tectônicos mais recentes. Dessa forma, grupos de fraturas com atitudes e espaçamentos relativamente semelhantes, seriam afetadas de maneira similar dentro de um mesmo domínio tectônico, e, portanto, apresentariam comportamento hidráulico análogo (Fernandes, 1997; Surrette et al., 2008).

São três os mecanismos de propagação de fraturas: (1) extensional, no qual os esforços de tração são perpendiculares ao plano de fratura; (2) cisalhante com deslocamento paralelo à frente de propagação; (3) cisalhante com deslocamento perpendicular à frente de propagação (Lawn \& Wilshaw, 1975). O mecanismo extensional gera, portanto, fraturas extensionais, que tendem a apresentar maior abertura, enquanto os outros mecanismos geram fraturas de cisalhamento. Há ainda fraturas híbridas, que se propagam mediante a atuação de mecanismos extensionais e cisalhantes, atuantes em períodos distintos.

Os mecanismos de propagação e reativação de fraturas operam com base nos esforços tectônicos máximo e mínimo ( $\sigma_{1}$ e $\sigma_{3}$, respectivamente) atuantes sobre os pacotes rochosos, e podem ser relacionados à abertura das fraturas. As fraturas mais transmissivas foram identificadas como (1) paralelas ao esforço horizontal máximo - $\sigma_{11}$, caracterizando fraturas extensionais; ou (2) que apresentem ângulo de até $30^{\circ}$ a $40^{\circ}$ em relação ao $\sigma_{1}$ no campo de esforço atual, caracterizando fraturas cisalhantes com deslocamento paralelo à frente de propagação (Barton et al., 1995; Ferril et al., 1999; Morin \& Savage, 2003).

Corroborando com essa conclusão, Fernandes observa recorrente correlação entre ambientes extensivos e maior transmissividade no fluxo de água em rochas fraturadas (Fernandes, 1997; Fernandes \& Rudolph, 2001; Fernandes et al., 2012). Ambientes cisalhantes, entretanto, comumente apresentam comportamento ambíguo: zonas de falhas podem atuar como barreiras hidráulicas, condutos, ou um sistema misto de barreira e conduto (Caine et al., 1996). Eventos neotectônicos (campos de esforços tectônicos mais recentes) são especialmente importantes, pois fraturas geradas ou reativadas por esses eventos mais recentes são recorrentemente 
associadas à uma maior capacidade de transmissão de água (Barton et al., 1995; Fernandes, 1997, Morin \& Savage, 2003; Fernandes \& Rudolph, 2001).

Portanto, é de interesse dos estudos hidrogeológicos distinguir os mecanismos de propagação e reativação de fraturas, uma vez que esses mecanismos condicionam a abertura das fraturas (Lawn \& Wilshaw, 1975). Em campo podem ser observadas feições diagnósticas, que permitam indicar os mecanismos de propagação de fraturas atuantes. Exemplos comumente encontrados são feições plumosas (plume) e do tipo costela (rib), relacionados às fraturas extensionais, ou estrias, falhamentos e indicadores cinemáticos, relacionados às fraturas de cisalhamento.

Como observado, os mecanismos de propagação de fraturas têm relação com a magnitude absoluta dos esforços tectônicos, mas sua configuração e ocasional deslocamento são dependentes da orientação espacial desses esforços ( $\sigma_{1}$, $\sigma_{2}$ e $\left.\sigma_{3}\right)$. Segundo a classificação de Anderson (1951), são três os regimes tectônicos que dão origem aos três tipos básicos de falhas: regimes extensional, compressivo e transcorrente (Figura 2). No (i) regime extensional, as fraturas extensionais são verticais a sub-verticais, e as falhas normais apresentam mergulho médio em torno de $60^{\circ}$; (ii) no regime compressivo, fraturas extensionais são horizontais a subhorizontais, e o mergulho médio de falhas normais é de $30^{\circ}$; (iii) no regime transcorrente, fraturas extensionais são verticais a subverticais, e falhas de cisalhamento tendem a ser verticais.

(a)

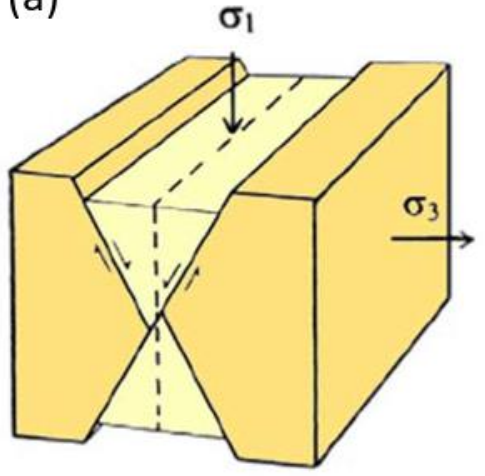

(b)

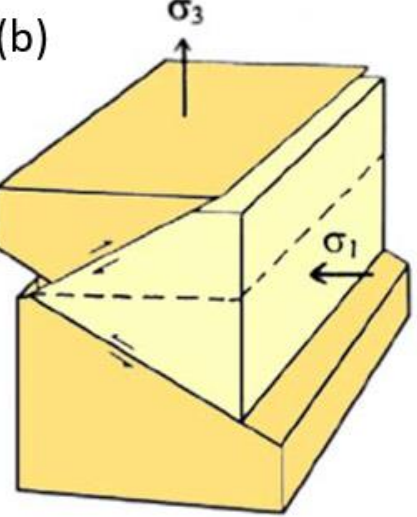

(c)

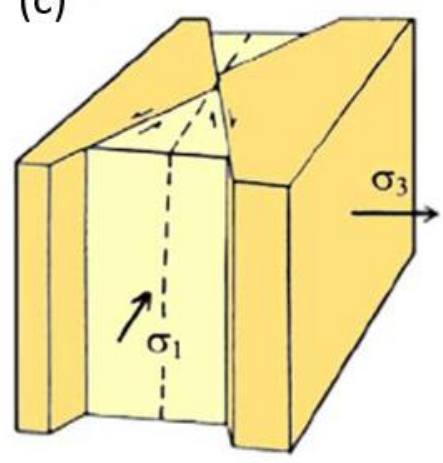

Figura 2: Regimes extensional (a), compressivo (b) e transcorrente (c). Fraturas extensionais em linhas tracejadas e fraturas de cisalhamento em linhas contínuas (modificado de Vialon et al., 1976). 


\subsubsection{Litologia do meio fraturado}

A litologia é diretamente relevante para a caracterização do fluxo de água, podendo formar condutos ou barreiras hidráulicas, ou indiretamente condicionar os padrões de fraturamento responsáveis pelo fluxo. No geral são observadas duas configurações em que a litologia é mais relevante, (1) sistemas limitados por estratos e (2) sistemas não limitados por estratos (Odling et al., 1999), ocorrendo também cenários mistos, com diferentes combinações entre esses dois sistemas.

Sistemas não limitados por estratos correspondem a aquíferos fraturados livres, e são o tema abordado neste trabalho. Nesses aquíferos a litologia pode ser condicionante do padrão de fraturamento ao favorecer a formação de planos preferenciais de ruptura, como foliações observadas em gnaisses ou dobramentos em rochas metamórficas, disjunções colunares em basaltos, ou até condicionar a extensão e densidade das fraturas, dependentes da tenacidade do material rochoso.

O contato entre diferentes litotipos, além de representarem possíveis caminhos preferenciais de fluxo, também pode condicionar a propagação das fraturas entre camadas com propriedades elásticas distintas (Engelder et al., 1993). Ainda, alterações em um mesmo litotipo podem configurar variações do fluxo de água, a exemplo de zonas de manto de intemperismo, que apresentam porosidade mais elevada e, teoricamente, maior transmissividade, ou a geração de minerais de alteração, que podem preencher fraturas, limitando o fluxo. A avaliação do fluxo na porção alterada da rocha é, entretanto, muito complexa devido à sua baixa homogeneidade espacial (UNESCO, 1984).

\subsubsection{Quantificação do fluxo em meios fraturados}

São dois os métodos mais usuais para a medição de fluxo no meio fraturado: (1) a abordagem do meio contínuo, que utiliza valores de condutividade, porosidade e compressibilidade para realizar aproximações (Domenico \& Schwartz, 1990), analisa o meio fraturado considerando-o como um meio poroso equivalente. Esse tipo de modelo comumente considera homogênea a distribuição das fraturas que cruzam o meio analisado, extrapolando-as para todo o pacote rochoso, o que raramente corresponde à realidade. $O$ segundo método é a (2) abordagem do meio descontínuo, supostamente mais eficaz por analisar individualmente as fraturas em relação às suas propriedades hidráulicas (Novakowski, 1995). Por considerar a heterogeneidade do meio, ou seja, fraturas diferentes contribuem diferentemente para 
o fluxo, esse método permite constatações em relação a capacidade transmissiva de fraturas individuais ou grupos específicos de fraturas.

Gale \& Rouleau (1983) e Briz-Kishore (1993) concluíram em seus trabalhos que a produção de poços locados em aquíferos fraturados é relativamente independente da quantidade de fraturas interceptadas pelo furo. Essa conclusão é corroborada pela lei cúbica (Equação 1), desenvolvida por Snow (1968), que relaciona a condutividade hidráulica do meio fraturado à densidade e à abertura das fraturas. $A$ lei cúbica é uma aproximação, desenvolvida para condições ideais, nas quais o fluxo é linear e laminar e as fraturas são delimitadas por paredes paralelas e lisas.

$$
\begin{array}{ll}
K=\frac{\rho g}{12 \mu} N b^{3} & \text { (equação 1) } \\
\mathrm{b}=\left(\frac{T 12 \mu}{n \rho g}\right)^{1 / 3} & \text { (equação 2) }
\end{array}
$$

Equações 1 e 2: equação da lei cúbica (1) e equação derivada da lei cúbica (2) (Snow, 1968).

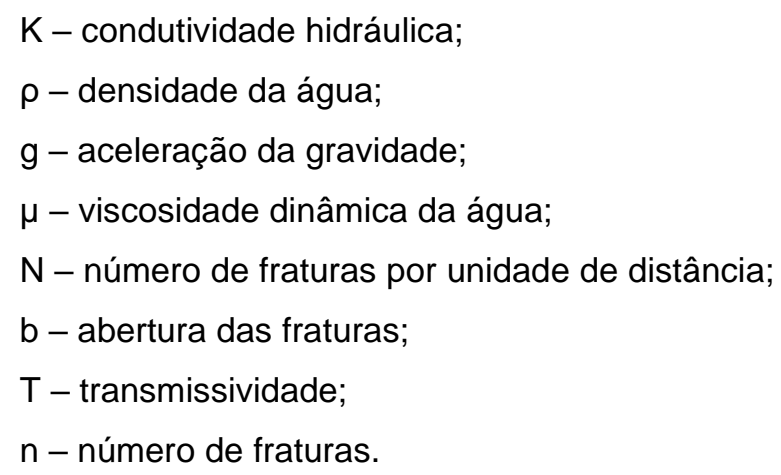

De acordo com a equação desenvolvida pelo autor, a condutividade hidráulica no meio fraturado é proporcional ao cubo da abertura das fraturas, e apenas diretamente proporcional à densidade de fraturas. A abertura das fraturas tem, portanto, maior relevância para a transmissividade e os caminhos preferenciais de fluxo de água subterrânea do meio. A medida de abertura de fraturas é comumente definida de maneira indireta; na prática a transmissividade $(T)$ do meio é obtida por meio de ensaios de campo, e por meio de uma segunda equação (Equação 2, derivada da lei cúbica) calcula-se a abertura hidráulica das fraturas. Dessa forma é determinada a abertura equivalente das fraturas, ou seja, calcula-se a abertura de 
uma fratura de paredes paralelas e lisas que apresenta valor de transmissividade (T) equivalente ao valor de transmissividade $(\mathrm{T})$ obtido no teste de campo.

\subsection{Métodos de Investigação Estrutural de Aquíferos Fraturados}

A escala de observação é de grande relevância para o estudo de aquíferos fraturados por ser condicionante de fatores fundamentais, como densidade, conectividade e extensão de fraturas (Odling, 1997). Robinson et al (2008) defendem uma abordagem de investigação denominada "top down", que aprimoraria a coleta de dados estruturais. De acordo com o método, a investigação da área de estudo é iniciada em menor escala, avançando para técnicas com maior grau de detalhamento. Essa abordagem se mostra adequado à investigação de aquíferos fraturados, visto que as altas heterogeneidade e anisotropia desses meios não são uniformes para diferentes escalas de observação, como é observado por Odling (1997) e extensivamente tratado por Fernandes (1997).

Como explanado no item 3.1.1. (Tectônica e padrões de fraturamento), as fraturas pertencentes a um mesmo grupo, quando compreendidas dentro do mesmo domínio tectônico, tendem a apresentar propriedades hidráulicas semelhantes. $\mathrm{Na}$ investigação de meios fraturados, um dos objetivos de maior relevância é, portanto, a identificação das descontinuidades correspondentes aos diferentes grupos, caracterizando-os por meio de dados obtidos em análises em diferentes escalas, como tratado nos itens subsequentes:

\subsubsection{Análise de lineamentos}

Lineamentos podem representar a manifestação superficial de estruturas geológicas, e a análise dessas feições é um método de análise indireto, útil na avaliação da geometria do aquífero fraturado e dos principais trends estruturais regionais (Fernandes \& Rudolph, 2001; Madrucci et al., 2005; Fernandes et al., 2007; Wahnfried, 2010; Fernandes et al., 2011; Pino, 2012; Fiume, 2013).

A análise de lineamentos é realizada a partir de um modelo digital de elevação (MDE), que é uma imagem que incorpora dados de altimetria do terreno, obtida por meio de um satélite. No imageamento superficial, falhas, zonas de cisalhamento e contatos litológicos podem gerar alterações geomorfológicas, manifestando-se como linhas alongadas que marcam o relevo. Essas feições são importantes pois, em subsuperfície, podem constituir condutos para o fluxo de água. 
Esse método de análise é uma abordagem inicial, não conclusiva, pois essas estruturas também podem representar barreiras hidráulicas, dependendo dos mecanismos que condicionam sua propagação (Francese et al., 2009), como explanado no item 3.1.1. (Tectônica e padrões de fraturamento).

Dessa forma, a análise de lineamentos deve ser realizada em conjunto com outros métodos de investigação, e não se deve assumir que todo lineamento observado é um conduto para o transporte de água subterrânea, o que seria uma forma muito simplista de interpretação. A geometria dos lineamentos (densidade, conectividade e orientação) soma-se a outros dados, como evolução tectônica, litologia, geofísica de superfície, observação de afloramentos e produtividade de poços (Fernandes \& Rudolph, 2001), para auxiliar o processo de caracterização das propriedades hidráulicas e contribuir para a elaboração do modelo de fluxo do aquífero (Fernandes, 2008).

\subsubsection{Levantamento estrutural em afloramentos}

Nos diversos estudos de aquíferos fraturados é recorrente a etapa de levantamento estrutural, principalmente nas fases iniciais de investigação, por meio de amostragens pontuais ou por métodos sistemáticos, como scanlines (e.g.: Alves, 2008; Chesnaux et al., 2009; Fernandes \& Rouleau, 2008; Fernandes et al., 2011; Pino, 2012; Fiume, 2013). A coleta e análise desses dados viabiliza a determinação do espaçamento entre fraturas e a definição dos principais grupos de fraturas, atentando em particular aos grupos mais transmissivos em relação ao fluxo de água subterrânea.

Entre os diversos métodos empregados na geologia e na engenharia, 0 método de amostragem por scanlines é ideal para a caracterização de sistemas de fraturas e de outras propriedades geométricas de grande escala, devido ao rigor estatístico e à relativa simplicidade do processo (Priest, 1993). Esse método, como explicitado por Chesnaux et al. (2009), permite a caracterização em grande escala das variações geométricas da rede de fraturas, possibilitando uma melhor representatividade estrutural do pacote de rocha e, consequentemente, das propriedades hidráulicas do aquífero fraturado. No método de amostragem por scanlines, é realizada a medição e registro das orientações, dimensões, características gerais das descontinuidades e relações geológicas entre diferentes 
grupos de descontinuidades ao longo de vários pontos do pacote rochoso (Priest, 1993).

Após a etapa de coleta de dados em campo, a principal etapa de tratamento dos dados estruturais é a correção do viés de orientação (Terzaghi, 1965). O viés de orientação ocorre devido ao ângulo de intersecção formado entre as fraturas e o plano do afloramento (Figura 3), e é ampliado quando há baixa variação na orientação das linhas de amostragem de fraturas (scanlines). Dessa forma, o resultado obtido inicialmente não representa adequadamente a proporção de descontinuidades de diferentes grupos de fraturas. Como exemplo, observa-se que sondagens verticais tendem a favorecer muito a amostragem de fraturas com menor ângulo de mergulho, desfavorecendo a amostragem de estruturas verticais (Priest, 1993). Dessa forma, a quantidade de fraturas de baixo ângulo é superestimada em detrimento das de alto ângulo, gerando, nesse exemplo, o viés de orientação.

Quando o ângulo $\alpha$, formado entre o plano aflorante observado e as fraturas amostradas, é diferente de $90^{\circ}$, observa-se no afloramento uma representação superestimada do espaçamento entre fraturas (denominado espaçamento aparente d'), subestimando, portanto, a densidade de fraturas nessa face da rocha. Quanto menor o ângulo $\alpha$, maior será o espaçamento aparente (d') em relação ao espaçamento real (d; Figura 3).

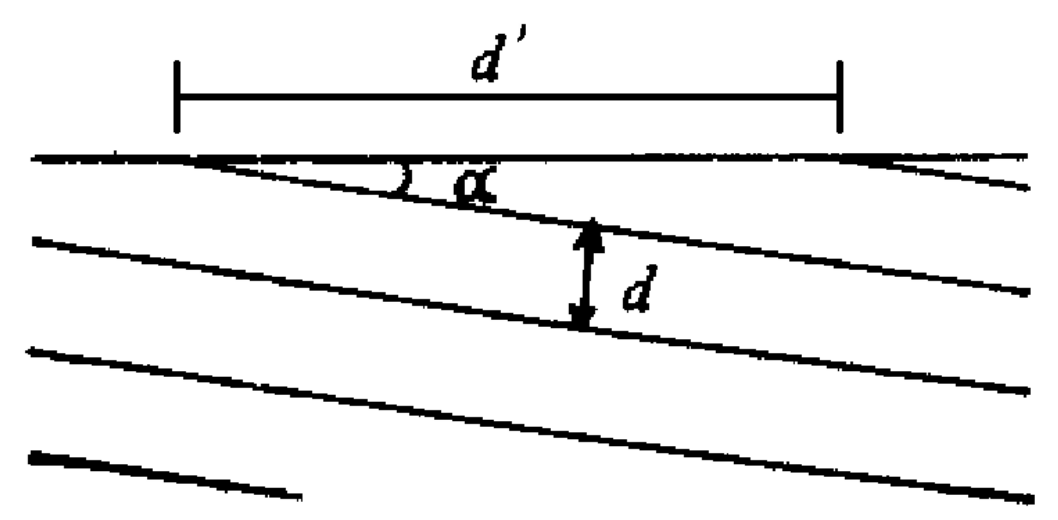

Figura 3: Exemplificação do viés de orientação. Espaçamento d', observado no afloramento, é muito maior que o espaçamento d real entre as fraturas, devido ao baixo ângulo a de incidência das fraturas na face observada (modificado de Terzaghi, 1965).

O viés de orientação pode ser atenuado ao aumentar o número de afloramentos com ampla variação nas orientações dos planos de rocha. A boa distribuição de orientações das faces amostradas resultará em uma melhor 
aproximação da densidade real de fraturas para cada grupo, com todos os grupos sendo amostrados mais uniformemente. As correções também devem ser realizadas após a coleta de dados, utilizando para isso a relação angular entre as fraturas e a superfície na qual elas foram medidas (Terzaghi, 1965). É recomendada, para efeitos de observação, a posterior comparação entre os dados brutos e corrigidos, a partir de plotagem em estereogramas (Pino, 2012).

\subsubsection{Geofísica de superfície}

A avaliação por métodos de geofísica de superfície é um recurso empregado costumeiramente para o fornecimento de dados complementares à investigação estrutural do pacote rochoso (e.g.: Madrucci et al., 2005; Guerra, 2010; Wahnfried, 2010), que, quando correlacionados aos dados obtidos em afloramentos, possibilitam uma melhor compreensão da distribuição espacial das descontinuidades que formam o aquífero. Muito mais que a simples identificação do nível freático em uma extensão contínua do aquífero, essas avaliações são úteis na identificação de trends estruturais e padrões de fraturamento (Degnan et al., 2004), possibilitando inferências diretas sobre o sistema de fraturamento e seu papel na conectividade do aquífero.

O Caminhamento Elétrico (CE) é uma técnica geoelétrica (que mensura a eletrorresistividade dos materiais) que tem por objetivo determinar descontinuidades laterais nos materiais geológicos. Para isso são executadas medidas de eletrorresistividade em profundidades constantes ao longo de um perfil, gerando uma pseudo-seção em 2D da subsuperfície. As técnicas geofísicas que mensuram eletrorresistividade têm bases técnicas discutidas por diversos autores (e.g.: Maillet (1947), Keller \& Frischknecht (1966), Orellana (1972), Telford et al. (1990) e Reynolds (2011). Essas técnicas consistem na geração de uma corrente elétrica (I) artificial no subsolo por meio de eletrodos posicionados em superfície ou subsuperfície, com a subsequente medição da tensão (V) gerada. A partir da relação (Equação 3) entre os parâmetros (conhecidos) tensão, corrente e distância entre eletrodos, calcula-se a eletrorresistividade aparente dos materiais em subsuperfície. 


$$
\rho=K^{*} \frac{\Delta V}{I}
$$

Equação 3: equação da eletrorresistividade.

$\mathrm{P}$ - eletrorresistividade;

$\mathrm{K}$ - fator geométrico de posição dos eletrodos;

$\Delta \mathrm{V}$ - diferença de potencial elétrico;

I - corrente elétrica.

Outro método de análise geofísica é a Sísmica de Refração, que utiliza o princípio físico das ondas sísmicas. Esse recurso é comumente empregado no estudo de porções mais rasas da subsuperfície, a poucas dezenas de metros de profundidade, com a finalidade do reconhecimento das propriedades mecânicas e físicas dessas primeiras unidades (e.g.: Dutta, 1984; Hatherly \& Neville, 1986; Neves, 1998).

Esse método consiste na captação das ondas longitudinais (ondas P). Essas ondas são geradas artificialmente por meio de energia mecânica imprimida ao solo a partir de um ponto de disparo, e são refletidas pelas camadas subsuperficiais. É medido então, por meio de geofones, o tempo de retorno das ondas sísmicas refletidas, possibilitando determinar parâmetros como a geometria das camadas e densidade das rochas, com maior resolução espacial que outros métodos.

Outra técnica derivada da Sísmica de Refração é a Prova MASW, que analisa as ondas cisalhantes (S), que se dispersam diretamente pelo solo. Embora esse tipo de onda seja considerado ruído para outros métodos geofísicos, tem sido utilizada em estudos desde a década de 50. Essa técnica foi definida ao final da década de 90 (Park et al., 1999), utiliza um maior número de geofones para registro das ondas do tipo $S$, de cisalhamento, o que permite a análise da compactação do terreno e sua capacidade de carga. 


\subsection{Contexto Geológico da Área de Estudo}

A Bacia de Volta Redonda, de idade paleogênica, juntamente às bacias de Resende, Taubaté e São Paulo, está inserida no Segmento Central do Rift Continental do Sudeste do Brasil (RCSB; Riccomini, 1989). O RCSB é uma depressão tectônica alongada, com cerca de $900 \mathrm{Km}$ de comprimento na direção NE-SW, estendendo-se do Paraná ao Rio de Janeiro, distando cerca de $70 \mathrm{Km}$ da atual costa do mar por toda sua extensão.

O RCSB tem idade paleogênica, e com seus diversos domínios está inserido no contexto tectônico da Província Mantiqueira, fazendo parte do segmento central da Faixa Móvel Ribeira (Heilbron et al., 2004). A Província Mantiqueira tem sua evolução desde o final do Proterozóico (900 a 520 Ma; Delgado et al., 2003) durante - Ciclo Brasiliano. Essa evolução teria ocorrido por meio de processos de amalgamação de terrenos Proterozóicos e retrabalhamento crustal de terrenos paleoproterozoicos, que deram origem ao paleocontinente Gondwana Ocidental (Heilbron et al, 2004).

A Faixa Móvel Ribeira apresenta quatro terrenos tectonoestratigráficos, divididos por falhas de empurrão ou zonas de cisalhamento. Os três primeiros são Ocidental, Oriental, Paraíba do Sul, amalgamados entre 605 e $580 \mathrm{Ma}$, e o último Cabo Frio, amalgamado durante o Cambriano (Heilbron, 1993, 1995). Heilbron et al. (2004) definiram quatro estágios evolutivos orogenéticos para as rochas neoproterozoicas que compõem o embasamento pré-cambriano da Região Sudeste, desenvolvidas a partir do Ciclo Brasiliano, são eles: (i) pré-colisional, de 790 a 635$620 \mathrm{Ma}$; (ii) sin-colisional (subdividido em colisional II, 590-560 Ma, e colisional III, 535$510 \mathrm{Ma}$; (iii) tardi-colisional, de 560 a $530 \mathrm{Ma}$; e (iv) pós-colisional, de 510 a $480 \mathrm{Ma}$.

\subsubsection{Litologia}

As unidades do embasamento ocorrem como corpos alongados de direção NE-SW, de acordo com o trend regional da Faixa Ribeira, e são formadas por complexos ortoderivados paleoproterozoicos, complexos paragnáissicos proterozóicos e suítes intrusivas proterozóicas e paleozoicas, inseridos nos domínios do Terreno Ocidental, Terreno Embu e Klippe Paraíba do Sul da Faixa Ribeira. A seguir são descritas as unidades litotectônicas da Faixa Ribeira aflorantes na região estudada. Como fonte foi utilizado o relatório das folhas (1:100.000) Santa Rita do Jacutinga, Barra do Piraí e Volta Redonda (PRONAGEO-UERJ/CPRM, 2007). 


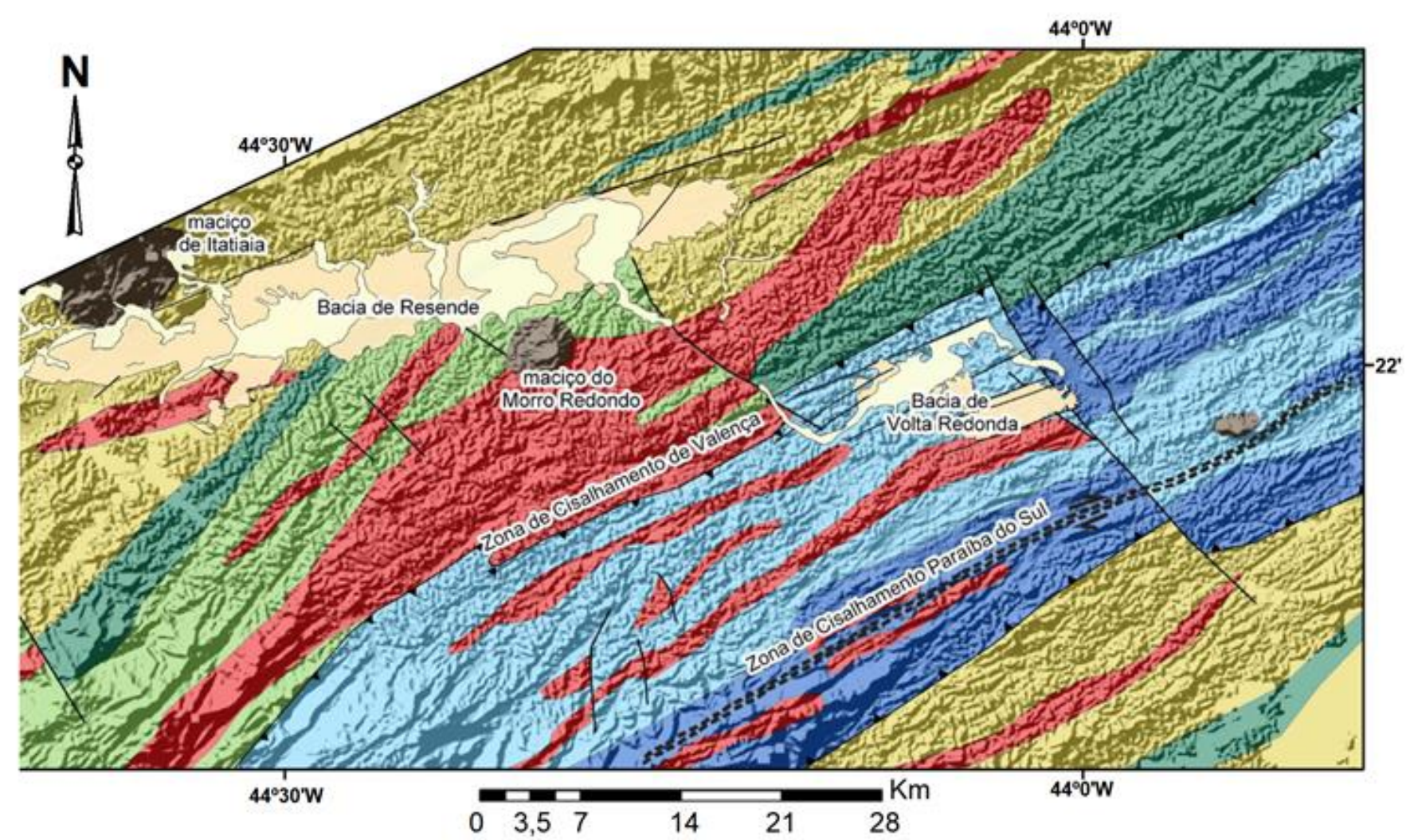

$\begin{array}{lll}\square \text { Depósitos quaternários } & \text { Granitóides sintectônicos brasilianos } \\ \square \text { Mepósitos terciários } & \text { Metassedimentos da } & \text { Maraiba do Sul } \\ \text { Megassequência Andrelândia } & \text { Ortognaísses do } \\ \text { Rochas alcalinas cretáceas } & \text { Complexo Quirino } \\ \text { Metassedimentos do } & \text { Complexo Embu } & \text { Ortogranulitos do Complexo } \\ \text { Juiz de Fora }\end{array}$

Figura 4: Mapa geológico simplificado do segmento central da Faixa Ribeira na região das bacias de Resende e Volta Redonda(modificado de Heilbron et al., 2004, por Negrão, 2014). 
- Complexo Juiz de Fora (Ortognáissico)

O Complexo Juiz de Fora tem idade paleoproterozoica, e, na área de estudo, é formado por ortognaisses migmatíticos, de paragênese metamórfica em facies granulito. As rochas granulíticas estão dispostas como escamas tectônicas, intercaladas com rochas da cobertura metassedimentar neoproterozóica, e são limitadas por zonas de cisalhamento (Heilbron et al. 2000). Essas lascas tectônicas ocorrem com frequência na região da Serra da Mantiqueira, e tem uma única ocorrência a norte da região da bacia de Volta Redonda, na região da Serra do Mar.

$\mathrm{Na}$ região de estudo, o Complexo Juiz de Fora é formado por ortogranulitos de composição variada, com predominância de enderbritos, charno-enderbritos e charnockitos, com ocorrência de noritos e charnockitos quartzosos. Predominância tipos tonalíticos, havendo, entretanto, composições graníticas a gabroicas. Lentes ultramáficas ocorrem subordinadamente; granulitos máficos tem composição gabróica; granulitos intermediários são quartzo-dioríticos, tonalíticos e granodioríticos; e granulito ácidos são granodioríticos e graníticos. Próximo às zonas cisalhantes são observados domínios com intensa milonitização e metamorfismo retrógrado, metamorfizando os ortogranulitos em gnaisses bandados (PPRONAGEO CPRM/UERJ, 2007; Negrão, 2014).

- Grupo Paraíba do Sul (Paragnáissico)

O Grupo Paraíba do Sul, de idade neoproterozoica, corresponde à cobertura metassedimentar do Terreno Paraíba do Sul, que inclui litotipos metamorfizados em facies anfibolito superior (Heilbron et al. 2000). Em sua porção basal são encontrados biotita gnaisses bandados, com bandamento composicional e migmatíticos (milimétrico a centimétrico), alternando entre níveis máficos ricos em biotita e níveis quartzofeldspáticos. É comum a presença de níveis abundantes em porfiroblastos de feldspato. Nas variações migmatíticas, de dimensões centimétricas a métricas, são observados leucogranitos foliados e níveis xistosos de granulação grossa, constituídos fundamentalmente por biotita. Nesses gnaisses bandados também são observadas intercalações lenticulares e boudins de rochas calcissilicáticas de coloração verde e alguns níveis xistosos.

Na porção mediana do grupo Paraíba do Sul é observado um gnaisse rico em micas, aproximando-se de um xisto, com camadas abundantes em sillimanita, quartzo e muscovita e níveis leucossomáticos, com granada e turmalina. Em algumas 
porções desse litotipo há a gradação para um gnaisse mais grosso, com porfiroblastos de feldspato e granada, e frequentemente são observadas intercalações lenticulares de rochas calcissilicáticas, mármores, anfibolitos e gonditos. Os mármores têm composição calcítica e dolomítica, aparecendo como lentes de diferentes dimensões, chegando a dezenas de metros; os anfibolitos também aparecem como lentes, boudins e corpos alongados, interpretados como diques metamorfizados, mas não ultrapassam mais de alguns decímetros de espessura (Marins, 2000).

A seção do topo é constituída por uma intercalação de um biotita gnaisse com xisto e um gnaisse pelítico rico em sillimanita, muscovita e biotita, o último assemelha-se à associação observada na porção mediana. A seção do topo se diferencia das demais por apresentar frequente intercalação lenticular, de dimensões centimétricas a métricas, de variados litotipos supracrustais, tais como: rochas calcissilicáticas maciças ou bandadas, gonditos, mármores e, subordinadamente, anfibolitos e quartzitos. Os dois últimos aparecem como lentes, semelhantes àquelas descritas anteriormente para a associação pelítica. A aparição de quartzitos é rara, são de granulação fina, com impurezas e formam lentes pouco espessas.

- Complexo Embu (Paragnáissico)

O termo Complexo Embu é amplamente utilizado como referência a um embasamento pré-cambriano paragnáissico, entretanto, ainda é muito debatido quais seriam seus limites espaciais. Neste trabalho será admitida a concepção adotada pelo PRONAGEO CPRM/UERJ (2007) em seu relatório, que denomina o Complexo Embu como gnaisses e xistos pelíticos com intercalação de quartzito e rochas calcissilicáticas, metamorfisadas em facies anfibolito, aflorantes na Serra da Bocaina, e sua vertente a norte, orientada para o Vale do Paraíba (Heilbron et al., 2000). Nesse trabalho o Complexo Embu, mais rico em quartzito, é separado do Complexo Paraíba do Sul, rico em rochas carbonática, embora não exista consenso quanto a idade dessa unidade ou sua relação com a segunda.

O Complexo Embu foi datado por Heilbron et al. (2000) como sendo provavelmente neoproterozóico, e foi subdividido em duas associações litológicas distintas, separadas pelo extenso corpo granítico Campo Alegre: 
a) A Unidade Rio Guaripu é truncada a nordeste pelo granito Campo Grande, esse gnaisse xistoso tem composição pelítica a semipelítica e comumente apresenta leucossomas anatéticos. Mineralogicamente apresenta sillimanita, muscovita e biotita, com ocorrência de granada e/ou turmalina nas porções gnáissicas e xistosas. Há porções de gnaisses finos, com muscovita e biotita, intercalados a lentes de rochas calcissilicáticas, quartzitos micáceos e, raramente, mármores e anfibolito.

b) A Unidade Rio Paraitinga aflora a norte do Granito Campo Alegre, sua constituição é muito similar à Unidade Rio Guaripu, com sillimanita-muscovita-biotita gnaisse/xisto, com granada e/ou turmalina, e muscovita-biotita gnaisse fino. As diferenças são as intercalações de rochas calcissilicáticas e quartzitos, que são mais espessas, e a ocorrência de níveis de estaurolita-muscovita-biotita xisto, granadahornblenda-biotita gnaisse fino e escassas lentes de tremolita xisto. Intercalações de níveis concordantes e centimétricos de turmalina sugerem origem vulcanossedimentar (Pereira, 2001).

- Suítes Intrusivas

Segundo datações geocronológicas e fases de deformação, são definidos cinco pulsos ígneos intrusivos principais (representados abaixo), responsáveis pela geração de inúmeros corpos granitoides, gerados durante a convergência neoproterozoico-eopaleozoica do segmento central da Faixa Ribeira (Heilbron, 1995; Heilbron et al., 2000 e 2003). Os principais corpos magmáticos remetem aos estágios sin-colisionais I e II, e, com base em dados geoquímicos e petrológicos, são classificados em granitos do tipo I (metaluminosos), do tipo $S$ (peraluminosos) ou híbridos.

- ca. 790-600 Ma, período pré-colisional e geração do arco magmático Rio Negro;

- ca. 600-560 Ma período sin-colisão I, colisão entre os terrenos Ocidental, Paraíba do Sul e Oriental;

- ca. 560-540 Ma período tardi-colisão I;

- ca. 535-520 Ma período sin-colisional II (Orogênese Búzios), colisão do Terreno Cabo Frio;

- ca. 520-480 Colapso Orogênico. 


\section{Suíte Campo Alegre}

A Suíte Campo Alegre aflora na região como dois corpos alongados com direção NE-SW, o maior deles tem cerca de $75 \mathrm{~km}$ de extensão, e está encaixado nas rochas metassedimentares do complexo Embu, no Terreno Embu. O Granito Campo Alegre relaciona-se ao estágio sin-colisional $\mathrm{I}$, e é descrito como um plúton granítico foliado, porfirítico, com cristais de K-feldspato com até $8 \mathrm{~cm}$ de comprimento e uma matriz rica em biotita, quartzo, plagioclásio, K-feldspato, granada e hornblenda. Além da facies porfirítica, ocorrem, subordinadamente, níveis de leucogranito equigranular foliado de granulação média. O Granito Campo Alegre é rico em enclaves lenticulares (xenólitos) de paragnaisses, xistos pelíticos e rochas calcissilicáticas, apresentando, em geral, contatos gradacionais com as rochas metassedimentares, indicando ser um granito do tipo S (Heilbron et al., 2004; PRONAGEO CPRM/UERJ, 2007).

\section{Suíte Rio Turvo}

A Suíte Rio Turvo é formada essencialmente por leucogranitos peraluminosos (tipo S), que aparecem sob a forma de plútons graníticos foliados (Heilbron et al., 2004). Na região o granito Rio Turvo aflora como três corpos alongados com direção NE-SW, encaixados em rochas do Domínio Juiz de Fora, concordantes à foliação regional. Machado et al. (1996) determinam a idade de intrusão do plúton em $579 \pm 6 \mathrm{Ma}$ (U-Pb em monazita), contemporâneo ao principal evento deformacional da região (D1+D2). Dados de Sm-Nd indicariam mistura de fontes paleoproterozoicas e neoproterozoicas, apesar dos baixos valores da proporção de isótopos $147 \mathrm{Sm} / 144 \mathrm{Nd}$, que podem significar outro grau de fracionamento do magma.

\subsubsection{Tectônica e deformação}

Heilbron et al. (2000) denotam as estruturas deformacionais do Orógeno Ribeira como resultado de colisões associadas à amalgamação da porção oeste do Supercontinente Gondwana. Com base em relações de metamorfismo, magmatismo, critérios de superposição e datação geocronológica, as estruturas deformacionais são relacionadas a quatro etapas sucessivas: D1 e D2, que são progressivas e mais penetrativas, representando a Deformação Principal; e D3 e D4, que representam a Fase de Deformação Tardia. 
- Deformação principal (D1 e D2)

Em escala regional, a Deformação Principal é responsável pela compartimentação tectônica da Faixa Ribeira, estabelecida pelo empilhamento de estruturas em escama, resultado do empurrão tectônico com sentido para o Cráton São Francisco. Dessa tectônica de empurrão são originadas dobras assimétricas, apertadas a isoclinais, que variam de recumbentes a inclinadas, com orientação dos eixos mais comumente para N/ENE.

O mergulho da foliação varia, portanto, entre NW e SE, sob a forma de clivagem ou xistosidade de crenulação, xistosidade recristalizada ou foliação milonítica. Exceto pelas zonas de cisalhamento tardias, marcadas pelas fazes de deformação mais recentes (D3 e D4), as principais estruturas dos Domínios Tectônicos do Segmento Central da Faixa Ribeira foram geradas pela Deformação Principal (D1 e D2), responsável pela principal etapa de encurtamento crustal.

\section{- Deformação Tardia (D3 e D4)}

Heilbron et al. (2000) descrevem estruturas posteriores à foliação gerada no primeiro evento colisional principal. Estas estruturas estão presentes em todos os domínios tectônicos do Terreno Ocidental, bem como nos Terrenos Embu, Paraíba do Sul e Oriental, e foram agrupadas nas fases de deformação D3 e D4 de acordo com critérios geométricos.

A deformação D3 é responsável por dobras empinadas abertas a apertadas, subordinadamente isoclinais, com eixos NE/SW de caimento subhorizontal e planos axiais com mergulho acentuado para SE ou SW. Exemplos principais das dobras geradas em D3 são a Megassinforma do Rio Paraíba do Sul (Heilbron et al., 1991) e a Megantiforma do Rio de Janeiro. Essas estruturas são facilmente reconhecidas em escala regional, por perturbarem o padrão estrutural estabelecido pela Deformação Principal.

Outra estrutura regional importante que remete à deformação D3 é o Lineamento de Além Paraíba, ou Zona de Cisalhamento Paraíba do Sul, com indicativos de componente dextral de movimentação e movimentação vertical inversa (Almeida, 2000). 


\section{- Tectônica cenozoica}

Riccomini et al. (2004) propõem quatro fases rúpteis para o segmento Central do Rift Continental do Sudeste do Brasil, sendo a primeira fase (E1) responsável pela abertura da bacia, enquanto as demais fases (TS, TD e E2) teriam caráter deformador. Sanson (2006) analisa as estruturas presentes na bacia de Volta Redonda, identificando e descrevendo essas fases rúpteis:

\section{Distensão NW-SE (E1):}

Essa fase inicial tem idade paleógena, e é responsável pela abertura, sedimentação e vulcanismo da bacia. Devido às reativações na fase E2, não é possível a obtenção de medidas estruturais indicativas da distensão responsável pela abertura da bacia, mas a análise de lineamentos e da distribuição de depósitos sedimentares possibilitaram constatações a respeito do regime distensivo inicial. $\mathrm{Na}$ Bacia de Volta Redonda são frequentes grandes lineamentos com orientação NE-SW, que aparecem como feixes contínuos, e formam as principais estruturas controladoras da sedimentação paleogênica.

Essas estruturas corresponderiam a zonas de cisalhamento reativadas por um regime tectônico distencional NW-SE (Roccomini, 1989; Riccomini et al., 2004), e estariam associadas à gênese da Bacia de Volta Redonda, visto que depressões tipo rift são áreas propensas à preservação do registro deposicional paleogênico (Sanson, 2006).

Transcorrência sinistral E-W (TS):

Sanson (2006) observa em campo falhas normais de direção NE-SW a NNE-SSW, falhas sinistrais normais e normais sinistrais NE-SW a NW-SE, e falhas normais dextrais e dextrais normais NNE-SSW e NNW-SSE. Os campos de tensão, obtidos a partir da análise dessas orientações, indicam esforços gerados a partir de distensões NW-SE com compressão NE-SW, condizentes com um regime transcorrente sinistral E-W. Segundo o autor, o sistema de falhas correspondentes a essa fase afetam exclusivamente os depósitos do Paleógeno, possibilitando inferir que essa fase tectônica se deu entre o Oligoceno final e o Mioceno. 
Transcorrência dextral E-W (TD):

São observadas em campo falhas normais WNW-ESE a NNW-SSE, normais dextrais NE-SW, ENE-WSW, WNW-ESE e NW-SE, e sinistrais normais NNW-SSE a NNE-SSW (Sanson, 2006). De acordo com o autor essas estruturas afetam depósitos sedimentares paleogênicos e coberturas neogênicas, e não são observadas em depósitos holocênicos fluviais e alúvio-coluviais. Essas relações de deformação, juntamente à observação de estrias associadas a esta fase tectônica, em sobreposição a estrias geradas no regime tectônico transcorrente sinistral, permitem inferir uma idade pleistocênica a esse evento tectônico.

\section{Distensão NW-SE (E2):}

As estruturas correspondentes a esse evento foram geradas por um campo de esforço puramente distencional com direção NW-SE. São observadas falhas normais NNE-SSW, NE-SW e ENE-WSW, que afetam desde os depósitos paleogênicos até os sedimentos holocênicos (Sanson, 2006). Com base nas relações estratigráficas, esse é considerado o evento tectônico mais recente observado na região da Bacia de Volta Redonda, com idade holocênica.

\subsection{Hidrogeologia}

Castro (2000) analisou a hidrogeologia da Bacia Resende, vizinha ao noroeste da Bacia de Volta Redonda, na qual reconhece três tipos de aquíferos: aquífero sedimentar livre, aquífero sedimentar multicamadas e aquífero cristalino fraturado, sendo o Rio Paraíba do Sul o nível de base regional.

Segundo o autor, o aquífero sedimentar livre compreende os depósitos quaternários, e foi identificado por toda a área da bacia. A precipitação é a principal fonte de recarga, e o aquífero superficial corresponde à principal fonte de recarga para os aquíferos subjacentes. $O$ aquífero sedimentar multicamadas é considerado de alta importância por Castro (2000), devido às suas propriedades hidráulicas e abrangência espacial, sendo o mais explotado da região. Esta unidade aquífera é muito heterogênea, compreendendo as unidades cenozoicas Acácias-Floriano e Resende.

Por meio de 8 poços profundos, foi constatado fluxo de água na porção cristalina em profundidades que variam de 23 metros a 133 metros. As informações acerca dessa unidade aquífera são, entretanto, muito limitadas, com testes de 
bombeamento realizados apenas para um poço (Castro, 2000). Albuquerque (2001) faz uma análise dos padrões de fraturamento neotectônicos na Bacia de Resende, e a partir desse critério subdividiu a bacia em cinco compartimentos principais, designados de A a E (Figura 5).

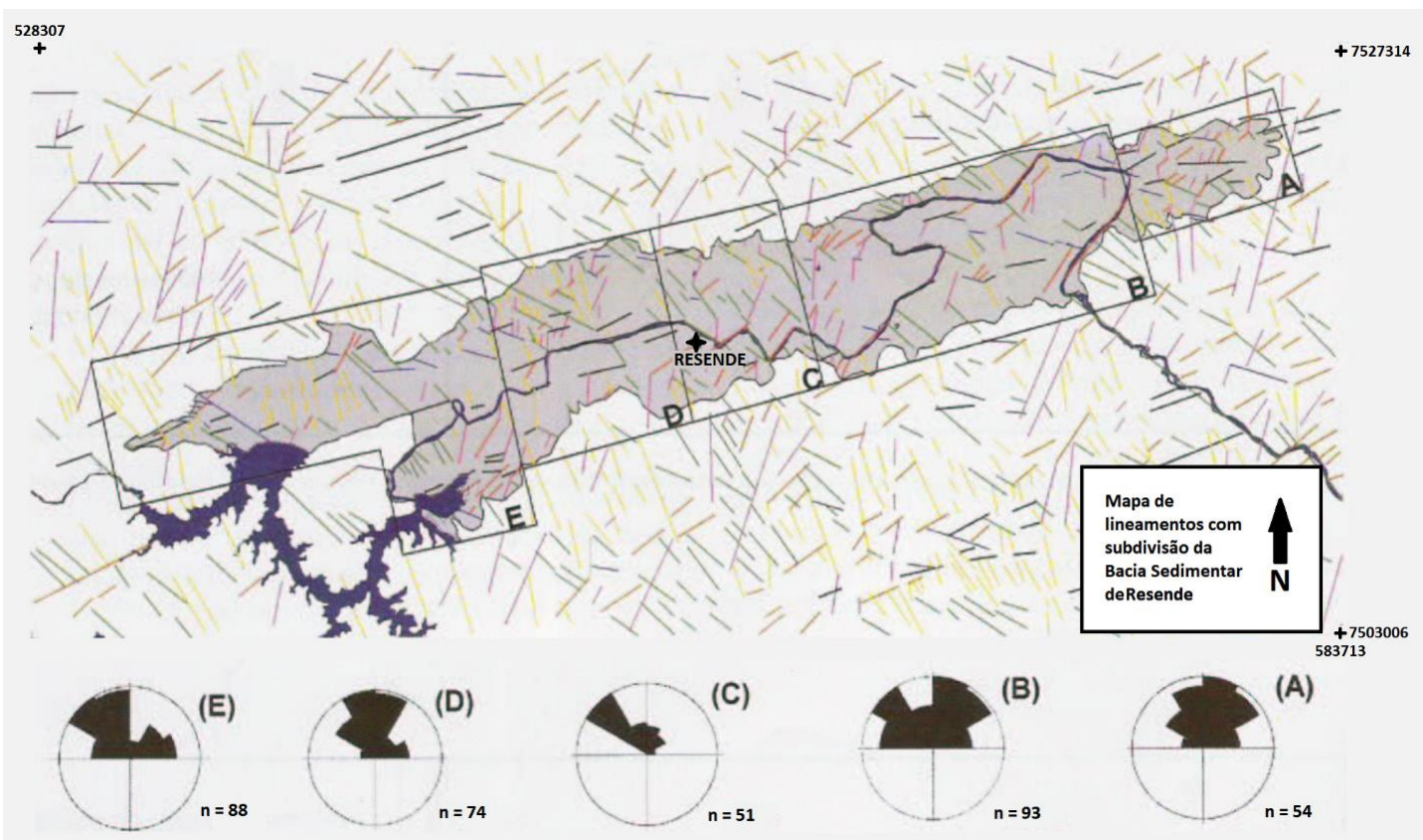

Figura 5: Mapa de lineamentos da Bacia de Resende, com subdivisão em compartimentos de A a E (Albuquerque, 2001).

Albuquerque (2001) correlaciona dados de vazão do aquífero sedimentar multicamadas (Castro, 2000) ao mapa de lineamentos, observando que os valores de vazão mais elevados ocorrem nos compartimentos $B$ e D. Esses compartimentos são os de maior frequência para lineamentos NNE e NE e lineamentos NW, respectivamente, e também são os compartimentos com maiores espessuras sedimentares e densidades de fraturamentos.

As maiores vazões registradas ocorrem no compartimento $B$, segundo um trend NE, e muito próximas às falhas de direção NE. Os poços que apresentam os valores de capacidade específica mais elevados também estão concentrados nos compartimentos $B$ e $D$, e muitos desses poços estão situados próximos ou sobre fraturamentos de direção NE e ENE, o que também ocorre para os poços que captam água no cristalino. Albuquerque (2001) afirma que a rápida recarga dos poços durante o bombeamento pode estar correlacionada às fraturas de orientação NE subjacentes, que apresentariam maior transmissividade, possível reflexo do último evento tectônico extensional NW-SE. 


\section{MATERIAIS E MÉTODOS}

\subsection{Análise de Lineamentos}

A análise de lineamentos foi empregada neste trabalho para avaliar preliminarmente e de maneira remota os principais trends estruturais da região estudada. $\mathrm{O}$ traçado dos lineamentos resultou em dois mapas, o primeiro com área de aproximadamente $300 \mathrm{Km}^{2}$, na escala 1:60.000, englobando estruturas de expressão regional e identificando grupos de lineamentos. O segundo mapa é de maior detalhe, abrangendo uma área de aproximadamente $40 \mathrm{Km}^{2}$, na escala 1:30.000, contemplando a área da unidade industrial e da pedreira.

Para a análise dos lineamentos, foi utilizado um modelo digital de elevação (MDE), elaborado a partir da integração de 4 MDEs menores. Os MDEs utilizados integram o projeto RJ-25 (IBGE, 2017), foram gerados por processamento fotométrico analítico com escala 1:25:000 e são disponibilizados pelo site do Instituto Brasileiro de Geografia e Estatística - IBGE.

O tratamento dos MDEs foi realizado com o ArcMap, principal componente do programa ArcGIS 10.1, desenvolvido pelo Instituto de Pesquisa em Sistemas Ambientais (ESRI). A ferramenta mosaic foi aplicada para fundir os MDEs; e em seguida a ferramenta hillshade foi aplicada para simular o sombreamento do modelo, ressaltando as formas de relevo. A utilização da ferramenta hillshade gerou dois MDEs secundários (Figura 6), com simulações distintas para a incidência de luz: (1) MDE com incidência de luz a $45^{\circ}$ (nordeste), ressaltando estruturas com direção NW-SE; (2) MDE com incidência de luz a $315^{\circ}$ (noroeste), ressaltando estruturas com direção NE-SW. Para ambos os MDEs, o ângulo vertical utilizado para a incidência da iluminação foi de $45^{\circ}$ em relação ao solo, com um fator $Z$ igual a 2 . 

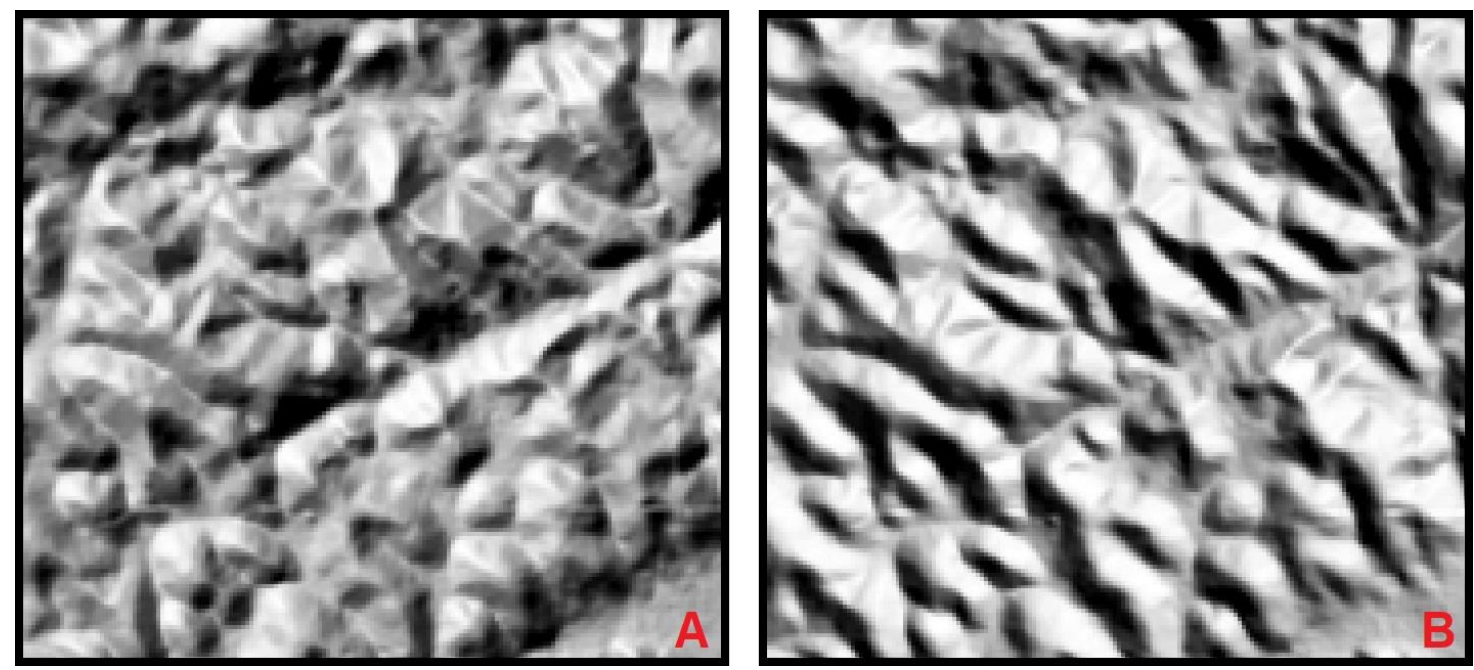

Figura 6: Exemplo de MDEs com diferentes direções de incidência de luz: A - $315^{\circ}$ (noroeste) e B $45^{\circ}$ (nordeste).

No programa ArcGIS, foi criado um shapefile de linhas sobre os MDEs, para o traçado manual de linhas sobre todas as feições representativas de lineamentos observadas nos MDEs. Esse processo foi realizado com um zoom equivalente a escala 1:25:000, e a alternância entre as duas incidências de luz (45ํ e $\left.315^{\circ}\right)$ permitiu a identificação de estruturas independentemente de sua orientação espacial. Ao todo foram traçados 485 lineamentos, cujas medidas de azimute e comprimento foram representadas graficamente em um diagrama de roseta gerado por meio da ferramenta Line Direction Histogram, do programa QGIS 3.2.3.

Seguindo a metodologia empregada por Negrão (2014), os lineamentos foram subdivididos em seis intervalos de acordo com suas orientações, favorecendo a visualização dos diferentes trends estruturais: (1) NNE (N01E - N20E); (2) NE (N21E - N70E); (3) ENE (N71E - N89E); (4) NNW (N01W - N20W); (5) NW (N21W - N70W); (6) WNW (N71W - N89W). Esse processo foi realizado por meio do programa QGIS 3.2.3, no qual o shapefile contendo todos os lineamentos foi subdividido em seis shapefiles, diferenciados por cor, favorecendo a visualização dos diferentes intervalos definidos.

\subsection{Levantamento Estrutural em Afloramentos}

A amostragem estrutural em afloramentos por scanlines foi empregada nesse projeto por seu rigor estatístico, ideal para estudos hidrogeológicos, nos quais se busca a melhor representatividade estrutural do aquífero. Em locais em que a amostragem por scanline não foi possível, devido às condições dos afloramentos 
encontrados, foram realizadas amostragens pontuais, para registro de feições estruturais relevantes.

O processo de amostragem por scanlines é prático e não demanda ferramental especializado, o que torna esse método economicamente vantajoso e aplicável em etapas iniciais de investigação. Os materiais necessários são: Sistema de Posicionamento Global (GPS), fita métrica, bussola geológica e formulário de campo.

Priest (1993) recomenda que a técnica seja aplicada em afloramentos com uma parede plana, limpa, relativamente grande em relação ao tamanho e ao espaçamento das descontinuidades observadas, atentando para a representatividade do afloramento em relação às demais rochas da região. Afloramentos com essa conformação são encontrados em falésias de praia, desfiladeiros, cortes de estrada e minas a céu aberto.

O método de scanlines consiste na projeção de uma linha horizontal (fita métrica) sobre o afloramento, perpendicularmente à direção de maior mergulho, a partir da qual são medidas e descritas todas as descontinuidades que a interceptam (Figura 7). Divergências no posicionamento da scanline inferiores a $20^{\circ}$ com a horizontal podem ser ignoradas, e caso haja variações maiores, a scanline pode ser subdividida em seções menores, cada qual com seu registro de direção e mergulho (Priest, 1993).
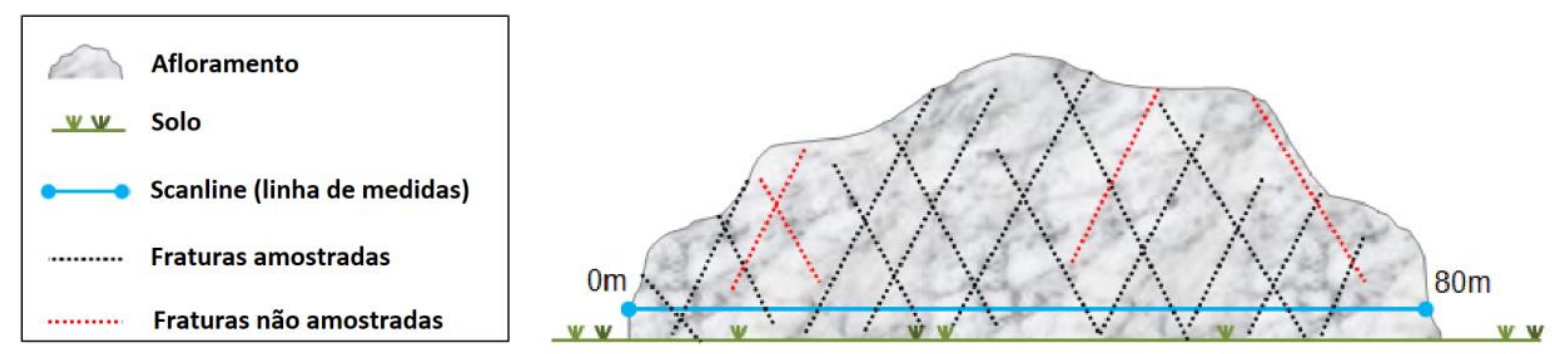

Figura 7: Esquema de amostragem por scanline para um afloramento de 80 metros. Apenas as fraturas (pretas) que interceptam a scanline (azul) são amostradas (modificado de Pino, 2012).

O processo de amostragem dos afloramentos é iniciado pelo registro de coordenadas, situação e dimensões do aforamento, atitude da parede, comprimento da scanline e, após o posicionamento da fita métrica, registro fotográfico para posteriores conferências visuais. A partir de uma das extremidades da trena são 
localizadas todas as descontinuidades que a interceptam, fazendo o registro de dados para cada descontinuidade.

Esses dados são registrados por meio de um formulário de campo (Anexo I), e posteriormente foram transcritos para uma planilha Excel, na qual os dados foram ordenados e tratados. Para cada descontinuidade foram registrados: localização na extensão da scanline, atitude, presença e atitude de estrias, tipo (junta, falha, zona de falha), comprimento, forma (plana, curva), rugosidade, alteração, revestimento, preenchimento, tipo de terminação (em outra fratura, em rocha, oculta etc), presença de água e/ou vegetação. Uma etapa importante do processo, que permite um melhor entendimento da relação entre as fraturas observadas, consiste no desenho manual do afloramento ou desenho sobre o registro fotográfico, representando ao menos uma fratura de cada um dos grupos identificados no afloramento.

Priest (1993) enfatiza que não há padrões universais para a aplicação desse método, sendo pertinente modificar certos aspectos da técnica, quando necessário, com o objetivo de adequá-la a condições singulares de corpos rochosos ou prover dados específicos a um modelo de pesquisa. Assim como em outros trabalhos em que a geologia estrutural é aplicada à hidrogeologia, além das informações regulares de registro para cada descontinuidade, foram coletados dados complementares, relevantes ao estudo de hidrogeologia, como: direção e mergulho de estrias de cisalhamento, cor e espessura de alteração e preenchimento, presença de água e/ou vegetação. A seguir são detalhados alguns dos itens registrados para cada descontinuidade:

- Localização na scanline: distância em metros da fratura a partir do ponto inicial da scanline. Durante o processo de análise da scanline deve-se atentar à presença de descontinuidades não naturais, produzidas por escavação ou desmonte com explosivos, atividades comuns em cortes de estrada e em pedreiras.

Em determinados estudos, como o de aquíferos fraturados, apenas as descontinuidades naturais são relevantes, pois fraturas de origem antrópica não são representativas do corpo rochoso na escala do aquífero. Fraturas naturais tendem a ser extensas, relativamente suaves, levemente curvadas, e comumente apresentam sinais de intemperismo, manchas e preenchimento. Fraturas não naturais normalmente são curtas, ásperas, irregulares, limpas, de orientação aleatória e comumente associadas a furos de perfuração ou explosão. 
- Rugosidade: refere-se a irregularidades na superfície das fraturas, e sua classificação é feita visualmente, de acordo com o Coeficiente de Rugosidade de Junta (JRC; Figura 8; Barton e Choubey, 1977). Os valores de JRC são utilizados na geotecnia para determinar uma base de predição de resistência e deformidade das descontinuidades, e na hidrogeologia podem ter relação com a variação de abertura das fraturas e o tipo de fluxo de água (laminar ou turbulento).

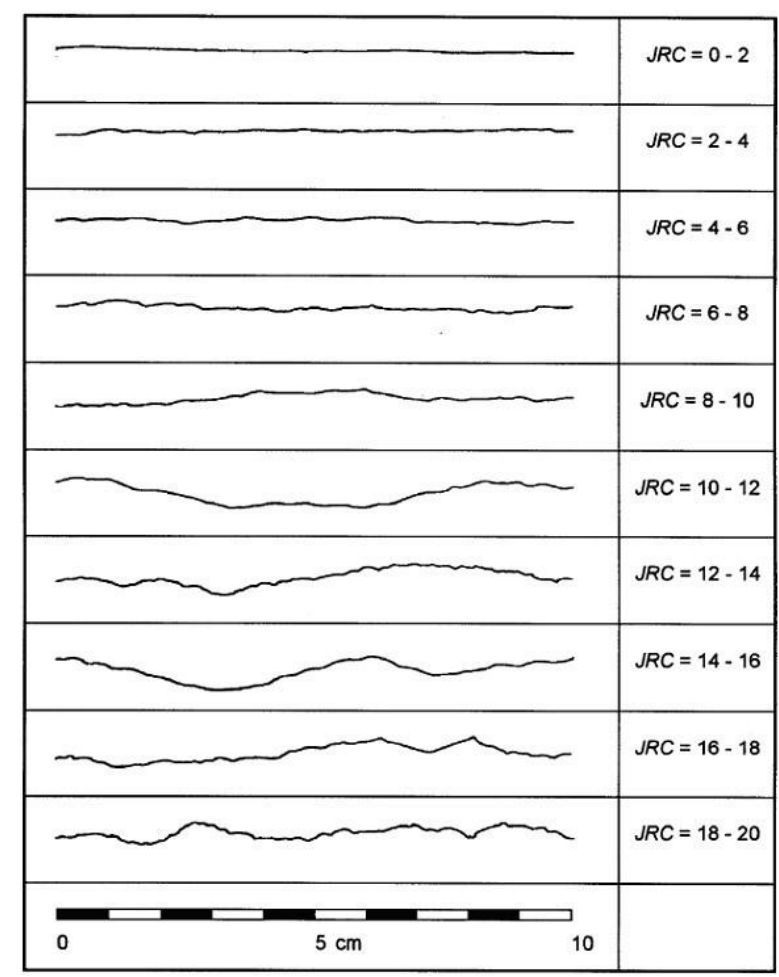

Figura 8: Tabela guia para determinação do Coeficiente de Rugosidade de Junta (JRC, Barton e Choubey, 1977).

- Presença de água e/ou vegetação: é pertinente registrar não só a presença de água, mas também de vegetação, que pode ser um indicativo indireto da presença de água. A presença de água percolante em uma descontinuidade revela a existência de abertura hidráulica para a passagem de fluxo, sustentando a hipótese da participação dessa descontinuidade como caminho preferencial no fluxo local de água.

- Atitude de estrias de cisalhamento: assim como os padrões de fraturas e a interação observada entre fraturas, os dados de estrias são relevantes para a análise neotectônica. Possibilitam o entendimento do tipo de falhamento observado e da evolução da deformação, etapa importante na definição dos grupos de fraturas de maior relevância para os caminhos preferenciais de fluxo de água subterrânea. 
Concluída a etapa de campo, inicia-se o tratamento dos dados coletados, sendo a principal etapa, a correção do viés de orientação. Os princípios básicos de correção desse viés, desenvolvidos por Terzaghi (1965), foram adaptados a um método computadorizado, em planilha digital, pelo Centro de Estudos de Recursos Minerais (CERM; Pino, 2012), na Universidade do Quebec em Montreal (UQAC). Como explanado no item 3.2.2. (Levantamento estrutural em afloramentos), a correção do viés de orientação permite uma melhor estimativa da densidade de fraturas de cada grupo.

O método original (Figura 9; Terzaghi, 1965) corrige a defasagem do espaçamento aparente (d') para o espaçamento real (d) entre as fraturas de um grupo. Essa defasagem se relaciona ao ângulo ( $\alpha$ ) formado entre a face observada, na qual é projetada a scanline, e o plano das fraturas que interceptam essa face. Com essas informações é feita a correção do número de fraturas $(\mathrm{N \alpha})$ presentes ao longo de uma scanline de comprimento $L$, plotando em um estereograma o número de fraturas (N90) que seriam observadas nessa mesma extensão (L) caso as fraturas fossem perpendiculares à face observada.

De acordo com a o esquema abaixo (Figura 9), o número corrigido de fraturas (N90) é obtido atribuindo peso '1/sen a' ao número de fraturas observadas $(\mathrm{Na})$. Para fraturas com ângulos menores que $20^{\circ}$ a correção não é feita (atribui-se peso zero, devido à baixa acurácia de amostragem). Essa exclusão é feita pois, para a escala de afloramento, não é possível determinar se a fratura de ângulo $\alpha<20^{\circ}$ é uma descontinuidade isolada ou pertence à um grupo de fraturas com um grande espaçamento aparente (d'), causado pelo baixo ângulo de intersecção ( $\alpha$ ). Nesses casos considera-se que essas fraturas serão amostradas em afloramentos com outras orientações, nos quais essas descontinuidades apresentarão ângulos de intersecção (a) maiores que $20^{\circ}$. 


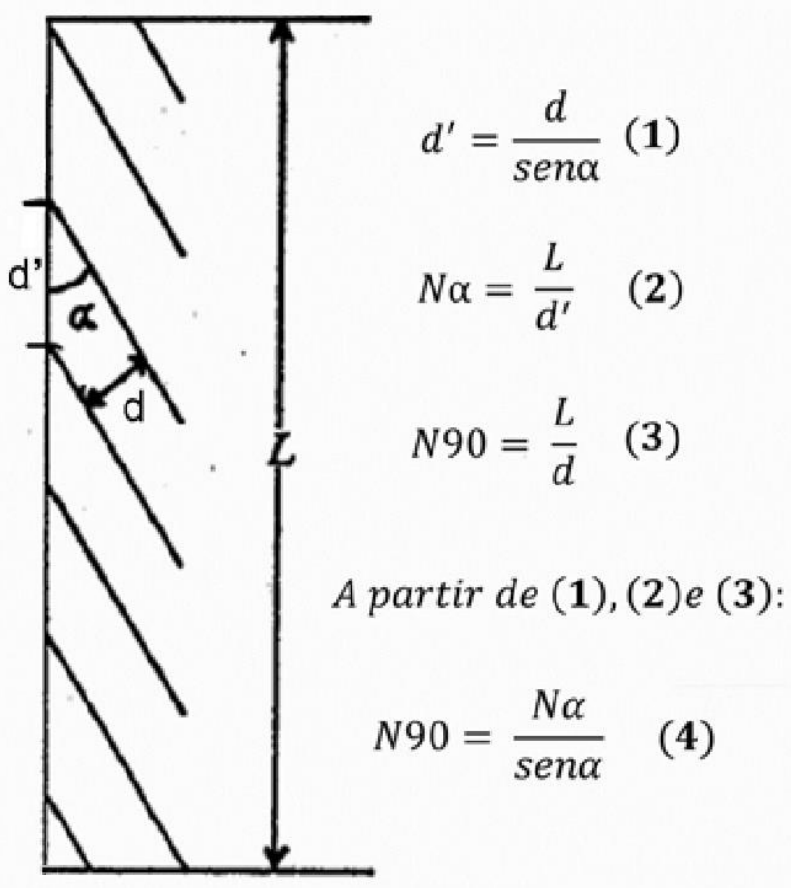

Figura 9: Determinação do peso ' $1 /$ sem $\alpha$ ', sendo: d' - espaçamento aparente; $d$ - espaçamento real; $\alpha$ - ângulo de intersecção; $L$ - comprimento observado; N90 - número corrigido de fraturas (Terzaghi, 1965, em Fiume, 2013).

A correção de Terzaghi (1965) foi aplicada por meio do método computadorizado supracitado, utilizando planilhas para ordenação e atribuição dos pesos e o software OpenStereo de projeção de estereogramas (Pino, 2012). Nesse método, para cada fratura com ângulos de intersecção $(\alpha)$ menor e maior que $20^{\circ}$ são atribuídos, respectivamente, pesos zero e $1 / \operatorname{sen} \alpha$, como no método original. Os valores obtidos são multiplicados por dez (10) a fim de gerar um número inteiro, adequando-os aos softwares de plotagem de estereogramas. Com esse processo, o número corrigido de fraturas (N90) será dez vezes superior, mas a proporção entre as fraturas totais permanecerá a mesma.

Com o número corrigido das fraturas de um mesmo afloramento, obtém-se estereogramas com contornos de frequência, que indicam os conjuntos de fraturas mais importantes desse afloramento. Além de permitir a correção das densidades relativas, o método proposto possibilita calcular os valores de densidade e, consequentemente, espaçamento para as descontinuidades. Para isso somam-se os valores N90 verdadeiros (não multiplicados por dez) obtidos para as fraturas de um mesmo grupo, dividindo o resultado pelo comprimento da linha de observação. Dessa forma é obtida a densidade, valor inverso ao espaçamento. É preciso notar que é 
possível calcular esses valores apenas para grupos que apresentem ao menos duas descontinuidades dentro da scanline.

\subsection{Geofísica}

Os métodos geofísicos de superfície foram empregados com o objetivo de obter informações sobre o substrato rochoso, como a profundidade do embasamento, a orientação de possíveis estruturas, a espessura do pacote sedimentar, a presença de matacões e o nível de água, contribuindo para o melhor entendimento da configuração geológica em subsuperfície. A determinação de presença e da orientação de fraturas e falhas são informações importantes para o entendimento do aquífero fraturado e do fluxo local de água subterrânea, por exemplo, quando correlacionadas a lineamentos observados em superfície.

As análises geofísicas foram executadas exclusivamente dentro do sítio industrial, onde ambos os métodos, caminhamento elétrico e sísmica, foram realizados ao longo de perfis que cruzam o sítio e em perfis curtos e paralelos, em áreas de maior detalhamento.

\subsubsection{Eletrorresistividade - caminhamento elétrico}

$\mathrm{Na}$ aplicação da técnica de caminhamento elétrico, foram utilizados eletrodos (barras de aço inox com cerca de 50 centímetros) cravados no solo ao longo dos perfis estudados (Figura 10). Para cada posição de medição um par de eletrodos ( $\mathrm{A}$ e $\mathrm{B}$, conectados a um amperímetro) é utilizado para gerar uma corrente elétrica, e um segundo par de eletrodos ( $\mathrm{M}$ e $\mathrm{N}$, conectados a um voltímetro) é utilizado para medir a diferença de potencial gerada pelo circuito de corrente. Dessa forma, são selecionados uma combinação de eletrodos $\mathrm{AB} / \mathrm{MN}$ para cada ponto medido em subsuperfície ao longo do perfil. 


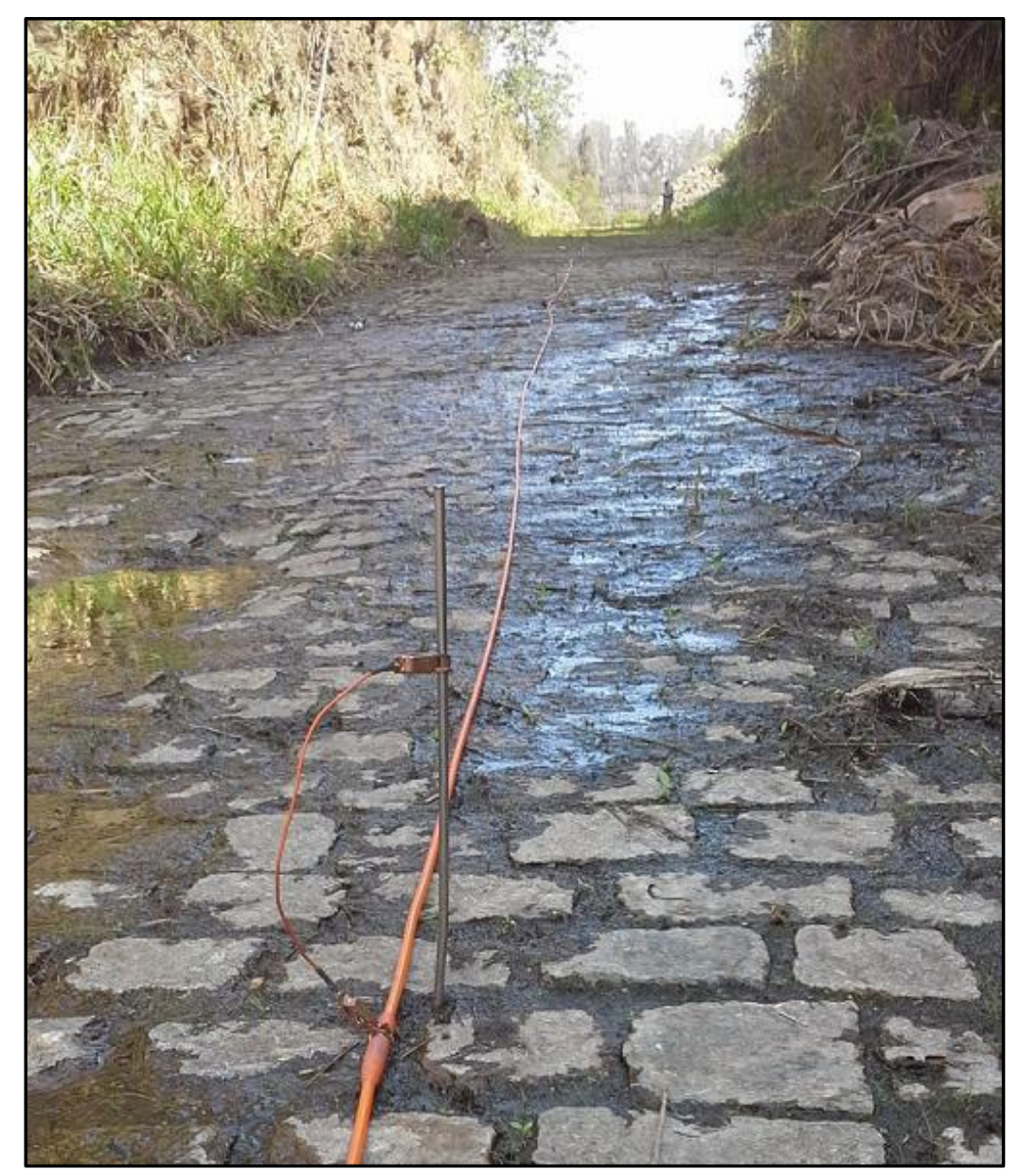

Figura 10: Eletrodos cravado no chão, conectado ao equipamento SYSCAL Pro por meio de garra jacaré e cabo multifilar.

O equipamento utilizado para a realização do caminhamento elétrico foi o SYSCAL Pro com 10 canais e 48 eletrodos, e a conexão entre os eletrodos e o SYSCAL Pro foi feita por meio de um cabo multifilar com vinte e quatro vias (Figura 10), preso aos eletrodos por meio de garras jacaré. O equipamento consiste em uma fonte de corrente para transmitir o sinal ao solo e um multivoltímetro para receber o sinal (tensão) e mensurar a corrente imprimida ao solo. O equipamento opera de forma automatizada, mensurando a corrente e a tensão nos eletrodos $\mathrm{M}$ e $\mathrm{N}$ e fazendo a comutação dos eletrodos para a sequência de medições.

A técnica de Caminhamento Elétrico pode ser aplicada com mais de uma configuração de posicionamento de eletrodos, sendo o arranjo dipolo-dipolo (Figura 11), utilizado neste trabalho, um dos mais precisos e rápidos para a aquisição dos dados. No arranjo dipolo-dipolo os eletrodos são dispostos ao longo do perfil com espaçamento igual entre os eletrodos de um mesmo par $(a=A B=M N)$. 
As medidas são efetuadas para vários níveis de profundidade, cada nível corresponde à intersecção das linhas com origem nos centros dos eletrodos $A B$ e $M N$ (combinação $A B / M N)$. Conforme são realizadas as medidas para os diferentes níveis, a seleção de eletrodos $A B$ avança lateralmente no sentido do caminhamento, realizando novas medidas ao longo do perfil.

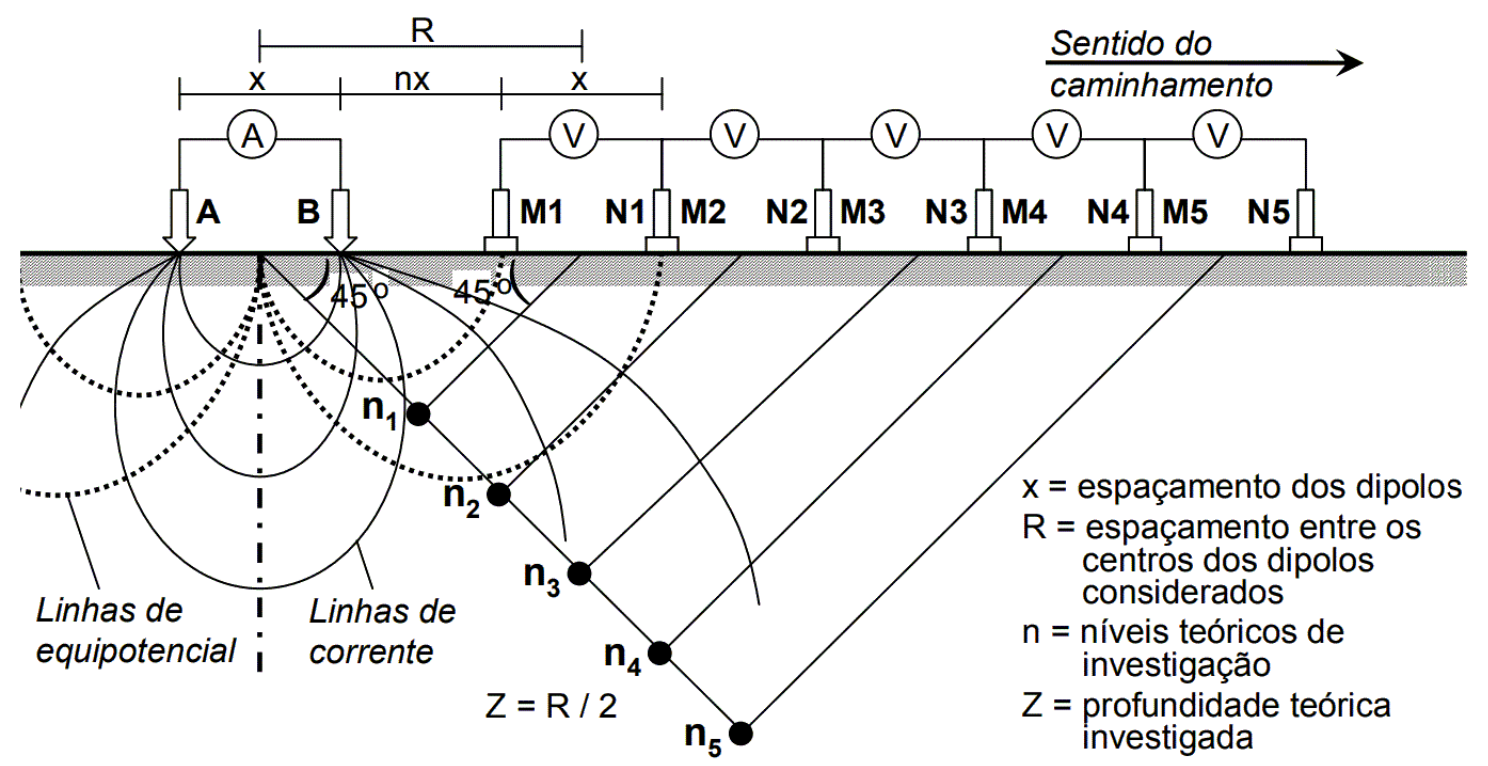

Figura 11: Configuração de posicionamento dipolo-dipolo. Diferentes níveis (n1, n2, n3...) são medidos para diferentes combinações $\mathrm{AB} / \mathrm{MN}$. Para o avanço horizontal das medidas, há a comutação de eletrodos no sentido do caminhamento, realizada automaticamente pelo equipamento (Braga, 2006).

Ao todo foram realizadas dezesseis linhas de caminhamento elétrico, gerando dezesseis perfis de eletrorresistividade. Para as diferentes linhas de perfil do caminhamento elétrico (Figura 12) foram utilizadas diferentes espaçamentos entre os eletrodos de um mesmo par (A): 2,5 metros para as linhas A1 a A3, B1 a B3 e C1 a C5; 5 metros para as linhas M1 a M3; 10 metros para as linhas L1 e L2. As linhas longas, L1 e L2, geraram perfis mais profundos, com até 80 metros; as linhas médias, M1 a M3, atingem profundidades de até 40 metros; as linhas dos perfis $A, B$ e $C$, de detalhe, aproximam-se dos 20 metros de profundidade.

As áreas de detalhe, nas quais as linhas têm menor abertura de eletrodos (perfis $A, B$ e C), são locais onde há indícios de contaminação. Apesar da menor profundidade analisada, a proximidade entre as linhas gera uma quantidade maior de informações, com maior detalhamento das camadas mais rasas. 

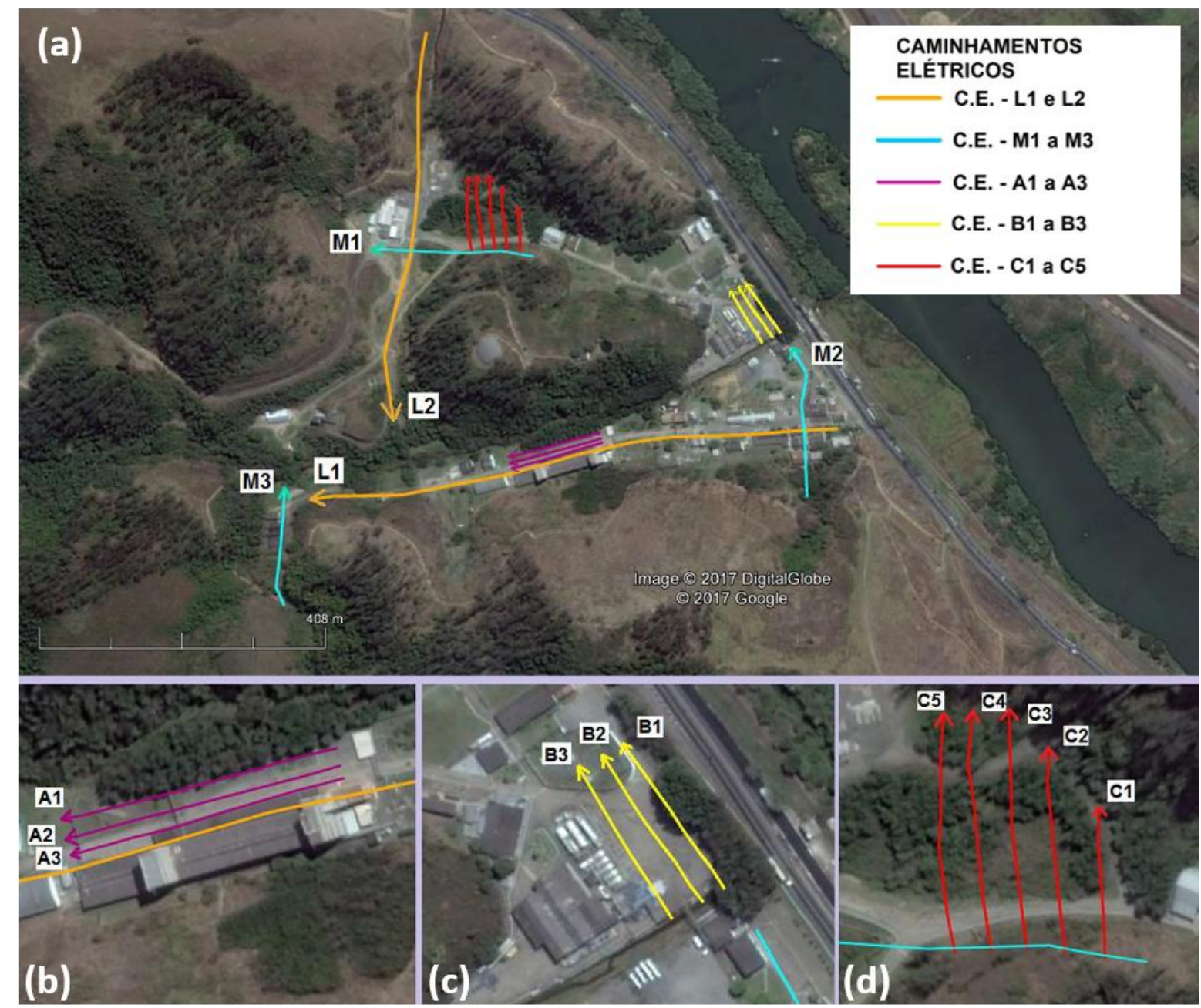

Figura 12 Localização dos perfis de caminhamento elétrico (a), com amplificação das áreas de detalhe (b, c, d) (modificado do Google Earth).

Como explanado anteriormente, as eletrorresistividades medidas pelos equipamentos são aparentes, sendo necessário a realização de correções para se obter o valor de eletrorresistividade real do meio estudado. Neste trabalho foi utilizado o programa RES2DINV para a inversão dos valores de eletrorresistividades aparentes das pseudo-seções em valores reais de eletrorresistividades, realizando também correção topográfica. O programa RES2DINV também foi utilizado na elaboração de modelos bidimensionais para os três perfis de detalhe. A maior densidade de dados nesses perfis possibilitou a interpolação, gerando planos horizontais contínuos dos valores de eletrorresistividade. 


\subsubsection{Sísmica de Refração e Prova MASW}

Os dados referentes às atividades de sísmica apresentadas nesse trabalho foram cedidos pela empresa de Consultoria Geofísica EEG Ltda. (2017). As técnicas sísmicas foram empregadas ao longo de quatorze linhas (Figura 13), gerando quatorze perfis; oito correspondentes à sísmica de refração e seis correspondentes à Prova MASW. O software usado para o processamento dos dados é o SurfSeis, desenvolvido pela Kansas Geological Survey (KGS).

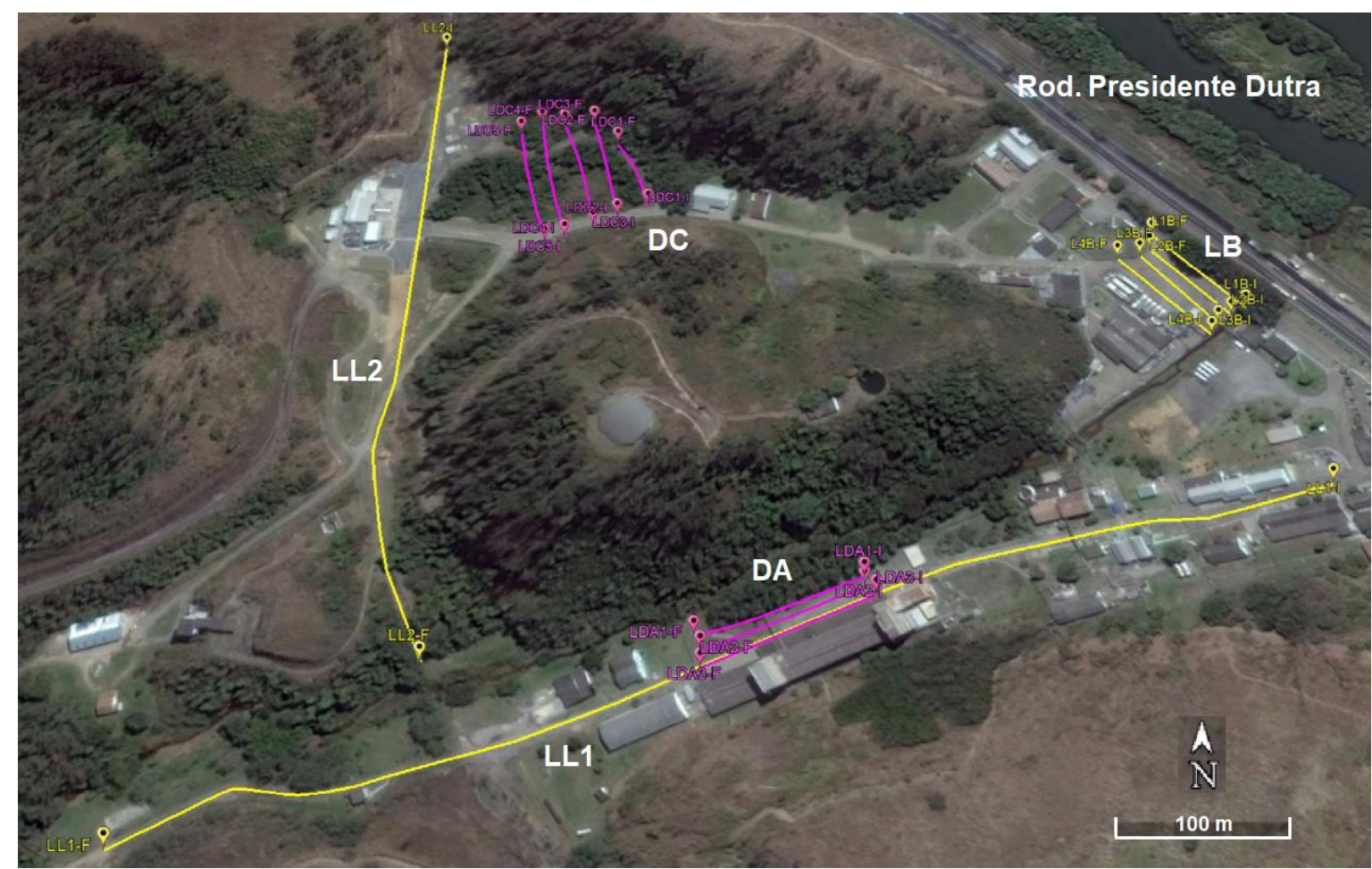

Figura 13: Localização dos perfis sísmicos. Perfis DA e DC (violeta) correspondem à sísmica de refração e perfis LL1, LL2 e LB (amarelo) correspondem à prova MASW (modificado de EEG, 2017).

A técnica de sísmica de refração é a mais adequada para a detecção do topo rochoso, não sendo indicada para áreas pavimentadas e/ou com alto ruído ambiente (próximo a rodovias). Dessa forma, a técnica MASW foi empregada nos perfis realizados ao longo de áreas asfaltadas ou próximos à Rodovia Presidente Dutra.

Os perfis de sísmica de refração foram realizados ao longo de linhas com, em média, 100 metros, investigando profundidades de 20 a 30 metros. A sísmica de refração foi aplicada utilizando 24 geofones com frequência de $8 \mathrm{~Hz}$, cravados ao longo dos perfis estudados, que captam as ondas sísmicas geradas a partir dos pontos de disparo. Para o registro dos impulsos sísmicos, os geofones são conectados a um 
sismógrafo por meio de dois cabos sísmicos multipolares de alta isolação elétrica (Figura 14), com separação de 5 metros entre sensores (possibilitando até 115 metros de extensão para cada perfil). O sismógrafo utilizado foi o ABM BR-24 com 24 canais, um equipamento eletrônico que amplifica, filtra e realiza a conversão digital dos impulsos captados.
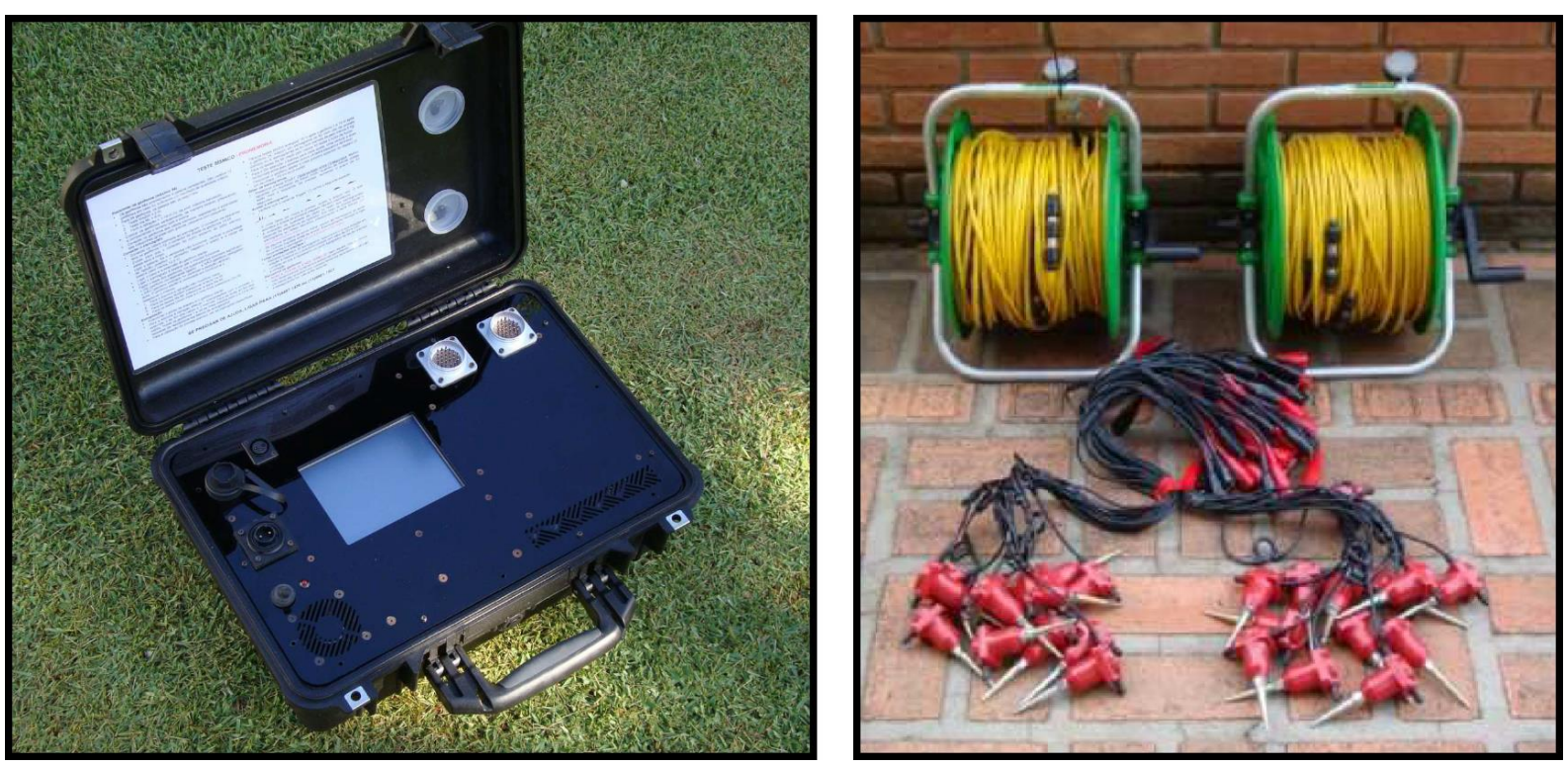

Figura 14: Sismógrafo ABM BR-24; cabos sísmicos multipolares de alto isolamento elétrico, com geofones (EEG, 2017).

Como dispositivo de energização, utilizado para gerar as ondas sísmicas no ponto de disparo, foi utilizada uma marreta de $10 \mathrm{Kg}$ e uma chapa de alumínio. Cada perfil de refração é energizado sete vezes, em diferentes pontos de disparo (Figura 15). A distância entre os pontos de disparo e os pontos de recepção (geofones), juntamente ao tempo de recepção medido, são empregados no cálculo das velocidades reais das ondas sísmicas ao penetrarem as camadas, bem como na determinação das espessuras, profundidades e inclinações dessas camadas. 


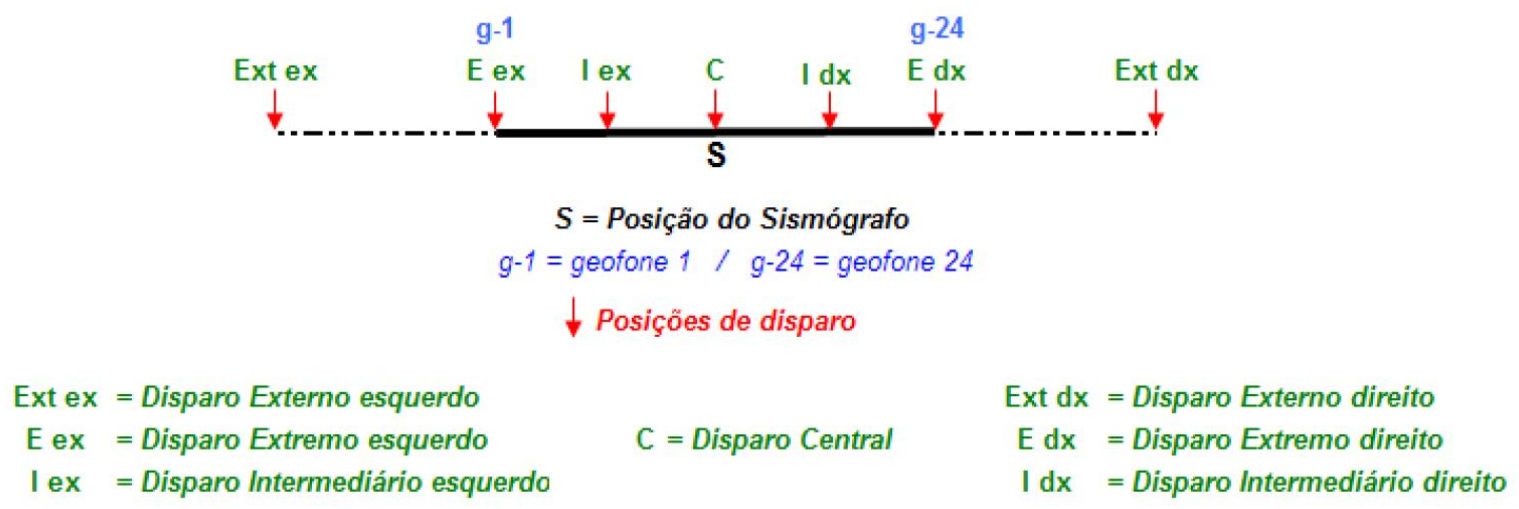

Figura 15: Configuração dos pontos de disparo para o perfil de sísmica de refração (EEG, 2017).

Para a realização da Prova MASW, foi utilizado o mesmo equipamento descrito para a sísmica de refração, com algumas modificações:

- Ponto de disparo sempre externo à linha de captação;

- Geofones com frequência de 4,5 Hz e espaçamento reduzido para 2,5 metros;

- Utilização do método de arranjo móvel dos geofones para alguns perfis.

Os perfis MASW de menor extensão tem em média 65 metros, investigando profundidades de até 25 metros, e utilizaram uma configuração com dois cabos sísmicos, totalizando 48 geofones fixos. Para a configuração fixa, a primeira medida é realizada com o ponto de disparo exterior a uma das extremidades, e apenas os 24 geofones mais próximos realizam a captação dos dados. As próximas medidas são realizadas com o ponto de impacto avançando de 5 em 5 metros ao longo da linha de geofones, e apenas os 24 geofones à frente do ponto de impacto realizam a captação das ondas.

Os perfis MASW LL1 e LL2 são os de maior extensão (750 metros e 490 metros, respectivamente), e investigam profundidades de até 50 metros. Esses perfis foram realizados sobre ruas pavimentadas, e para isso foi utilizada a técnica de arraste (Figura 16): o conjunto de 24 geofones é preso a um veículo e deslocado ao longo do perfil, realizando uma medida a cada 10 metros, sendo o ponto de disparo externo à linha de geofones. Para esse processo os geofones são montados sobre chapas de aço com 5 centímetros de espessura, facilitando o processo de arraste e melhorando o contato com o pavimento viário. 


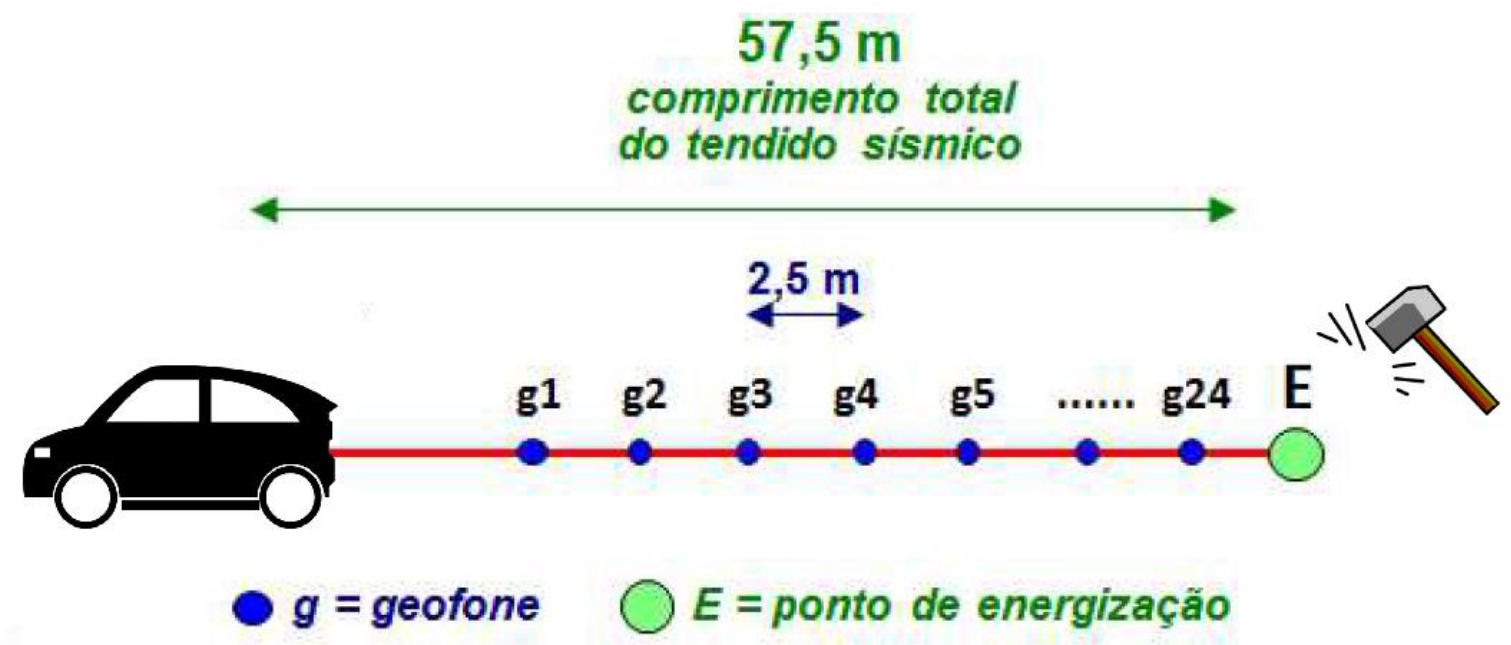

Figura 16: Configuração para execução da técnica de arraste, empregada nos perfis LL1 e LL2 (modificado de EEG, 2017). 


\section{RESULTADOS E DISCUSSÃO}

\subsection{Análise de Lineamentos}

O principal produto gerado pelo método de análise de lineamentos é o mapa na escala 1:60.000 (Figura 17), abrangendo uma área de aproximadamente 300 $\mathrm{Km}^{2}$, utilizado na determinação dos grupos de lineamentos e dos diferentes trends estruturais observados para a região. O mapa na escala 1:30.000, com uma área aproximada de $40 \mathrm{Km}^{2}$, foi gerado para dar maior detalhamento à área do sítio industrial e pedreira, foco do trabalho.

A partir do mapa 1:60.000, os lineamentos foram divididos em seis grupos de acordo com suas orientações, seguindo a metodologia de Negrão (2014). A roseta de frequência, apresentada no mapa, indica a existência de dois trends estruturais principais na região: o grupo de estruturas NW (vermelho) e o grupo de estruturas NE (verde) e ENE (rosa), sendo o último grupo concordante com a orientação geral dos contatos geológicos. Os lineamentos NW (vermelho) são mais numerosos e relativamente curtos, enquanto os lineamentos NE (verde) e ENE (rosa) são mais longos e contínuos, e aparecem cortando os lineamentos NW (vermelho).

Foi realizada a correlação entre lineamentos, fraturas e eventos tectônicos, assim como em Negrão (2014), o que tem por finalidade auxiliar o entendimento da influência dos eventos tectônicos na compartimentação tectônica da área de estudo, e, de maneira geral, a influência estrutural desses eventos.

- Evento E1 (distensão NW-SE)

Ao evento E1 são relacionados os lineamentos ENE (rosa), NE (verdes) e NNE (pretos), que aparecem como traços longos e contínuos. Negrão (2014) admite que as direções nas quais esses lineamentos estão associam-se à reativação de zonas de cisalhamento pretéritas, de mesma orientação, e os lineamentos seriam resultado do regime tectônico de distensão NW-SE, que atuou durante o Paleógeno. Lineamentos NW (vermelhos) e WNW (amarelo) também poderiam estar relacionados ao evento $E 1$, originando falhas transcorrentes dextrais, vinculadas ao estabelecimento de zonas de transferência. 


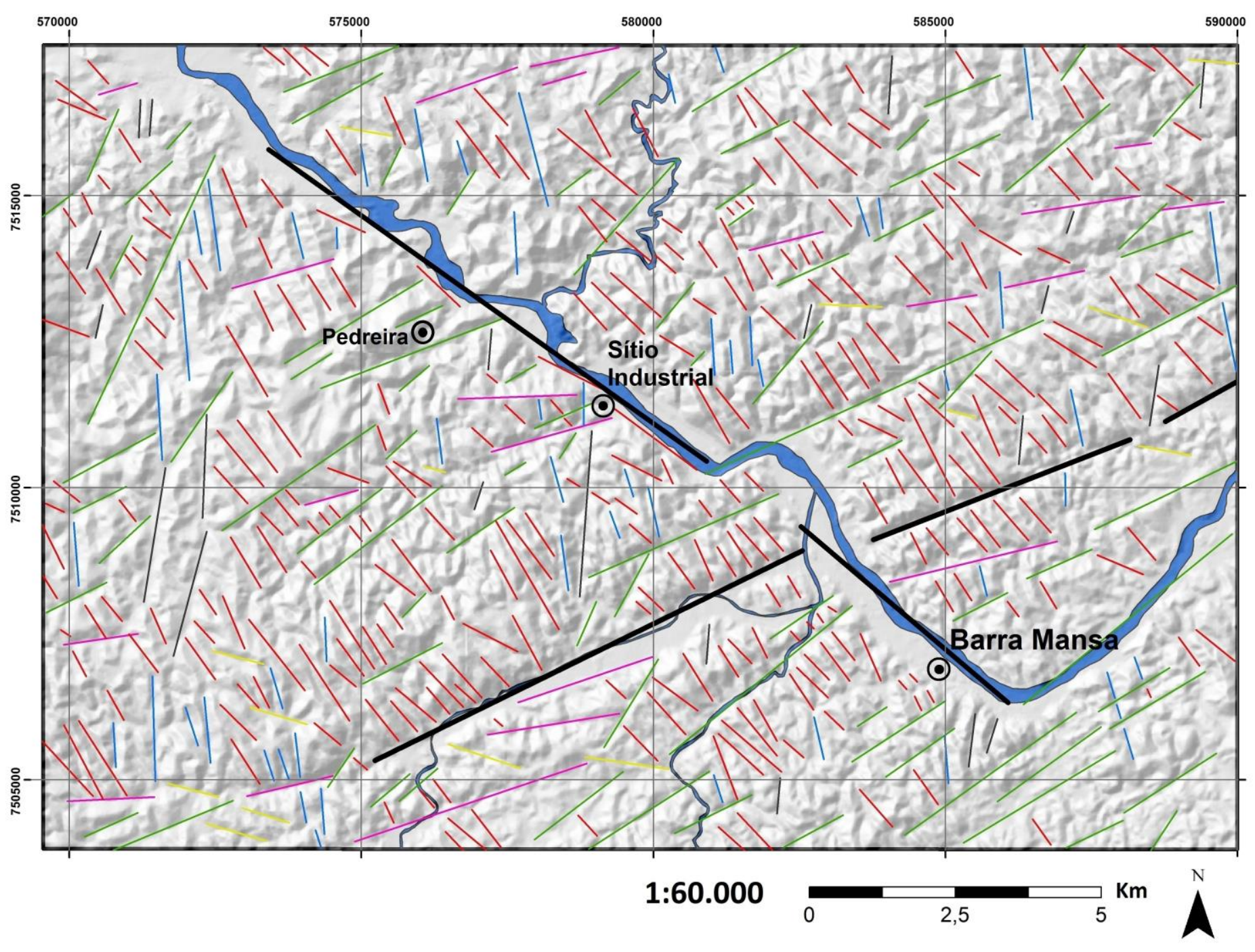

\section{LEGENDA}

\section{Lineamentos}

WNW (N71W-N89W)

NW (N21W-N70W)

NNW (N01W-N20W)

NNE (N01E-N20E)

- NE (N21E-N70E)

- ENE (N71E-N89E)

Estruturas regionais

Rio Paraíba do Sul

ح Rios tributários

Pontos de interesse

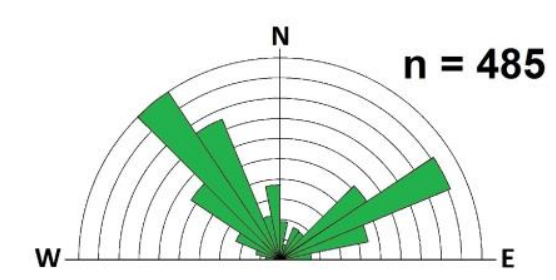

Geographic Coordinate System: Corrego Alegre 23S

Database: Project RJ25 - IBGE (2016)

Figura 17: Mapa de lineamentos regional com diagrama de roseta, representativo da frequência de orientação e comprimento dos lineamentos. 
- Evento TS (transcorrência sinistral E-W)

A esse evento estão relacionados os lineamentos de direção ENE (rosa), NE (verde) e NNE (preto), e os lineamentos WNW (amarelo), no geral com traços médios a longos, em feixes contínuos. De acordo com Negrão (2014), feições paralelas às do evento $\mathrm{E} 1$, marcariam morfoestruturas relacionadas à reativação de falhas de geração da bacia.

- Evento TD (transcorrência dextral E-W)

Em comparação aos demais eventos, as estruturas relacionadas ao evento TD (E-W) apresentam maior dispersão de orientação, mas também são as estruturas mais relevantes para a formação do relevo (Negrão, 2014). Ainda, em disparidade em relação aos demais eventos, o evento TD parece associar-se a todos os grupos de lineamentos. Isso se deve, possivelmente, à reativação generalizada das estruturas originárias dos eventos tectônicos anteriores, excluindo-se somente lineamentos NE (verdes).

- Evento E2 (distensão NW-SE)

A esse evento Negrão (2014) associa direções concordantes com os lineamentos NNE (preto), NE (verde) e ENE (rosa) como os mais significativos, relacionando essas estruturas a sistemas de falhas normais recentes, de idade holocênica, responsáveis pela reativação de estruturas pretéritas.

Adicionalmente ao mapa da Figura 17, foram traçados lineamentos em mapas de maior detalhe da área de interesse, sítio industrial e pedreira. Dois mapas na escala 1:30.000, sobre as bases MDE (Figura 18) e imagem fotográfica de satélite (Figura 19), permitem visualizar a disposição dos lineamentos observados dentro da unidade industrial e arredores. A roseta de frequência relacionada aos mapas de maior detalhe indica uma maior manifestação de lineamentos NW (vermelho) e NNW (azul). 


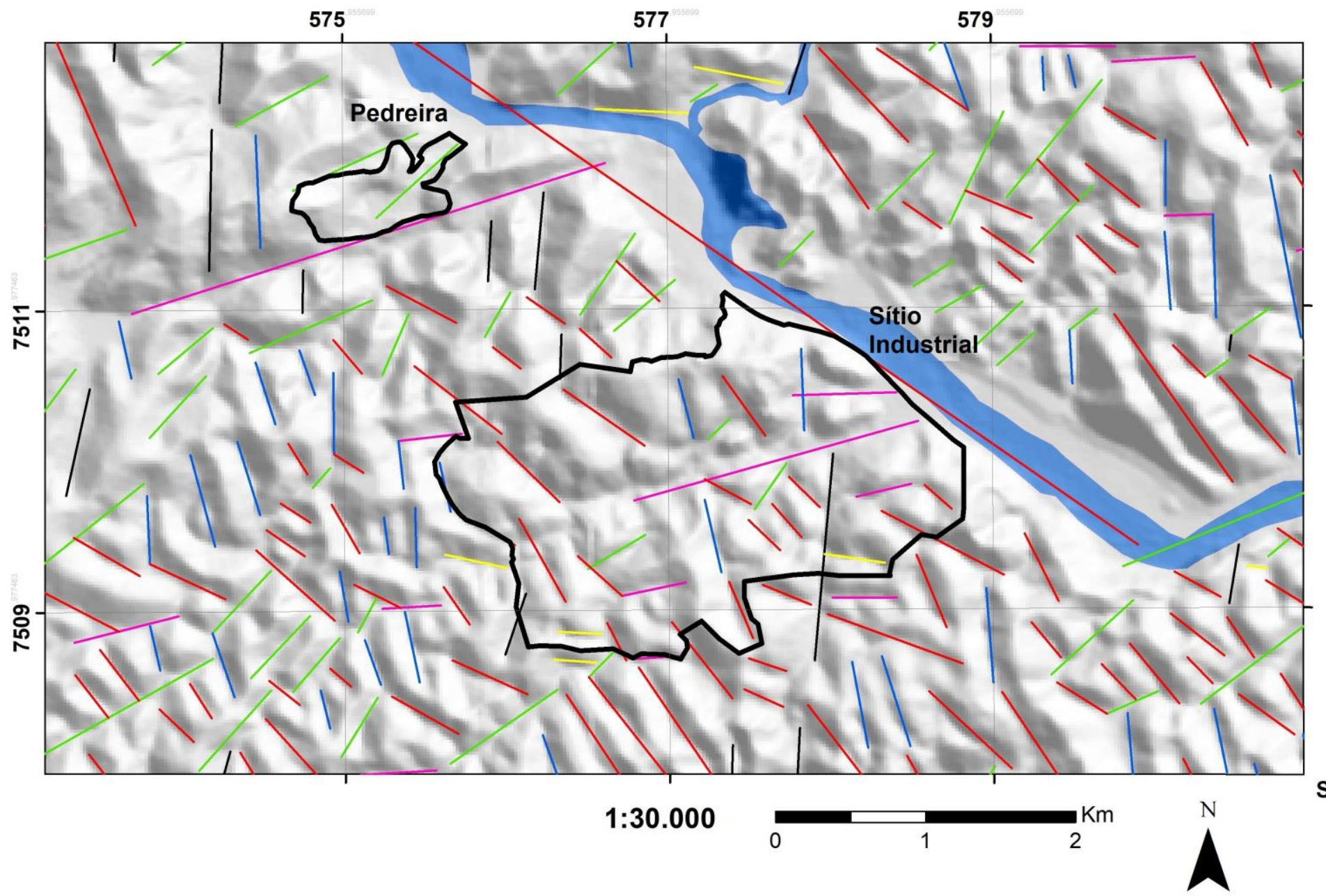

\section{LEGENDA}

WNW (N71W-N89W)

NW (N21W-N70W)

NNW (N0OW-N2OW)

NNE (N01E-N20E)

NE (N21E-N70E)

ENE (N71E-N90E)

$\checkmark$ Rio Paraíba do Sul

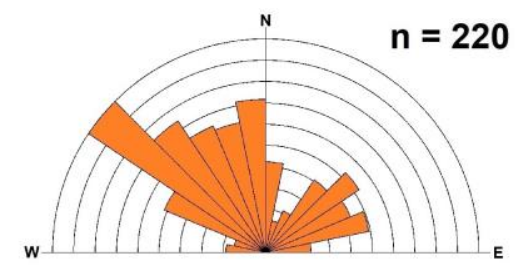

Figura 18: Ampliação do mapa de lineamentos com foco no sítio industrial, base Modelo Digital de Terreno (MDE). 


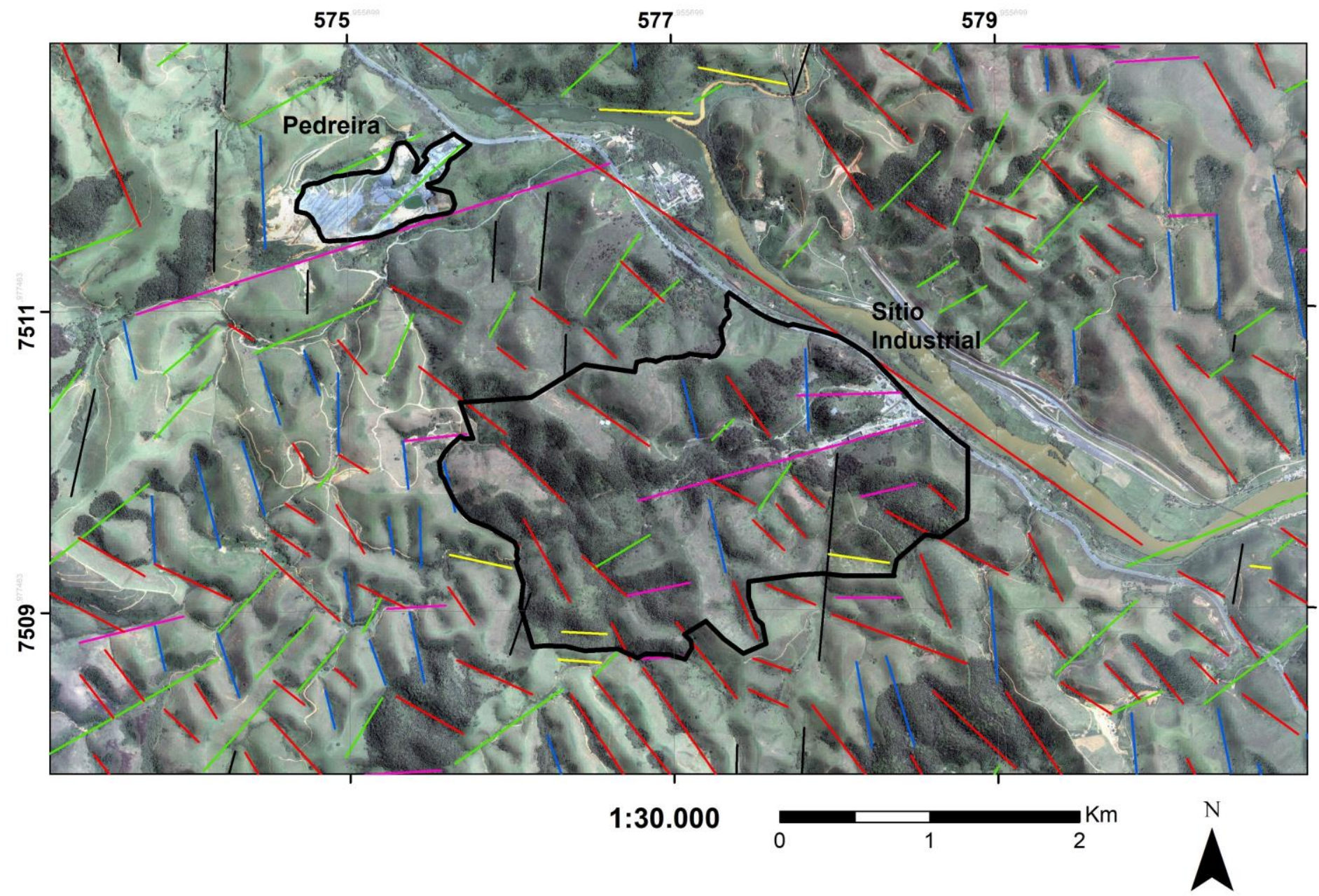

\section{LEGENDA}
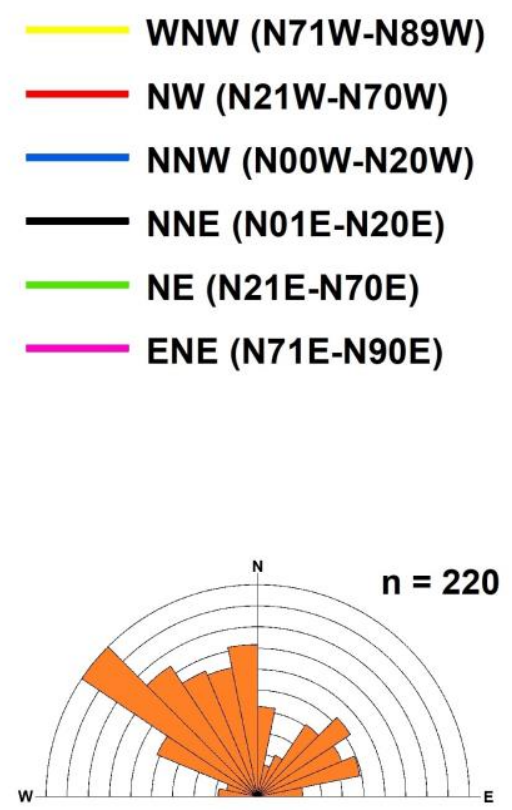

Figura 19: Ampliação do mapa de lineamentos com foco no sítio industrial, base imagem fotográfica de satélite (Google Earth). 


\subsection{Levantamento Estrutural em Afloramentos}

As localidades em que o levantamento estrutural foi realizado são a pedreira Pombal, incluindo um afloramento adjacente denominado ponto $E$, e o sítio industrial.

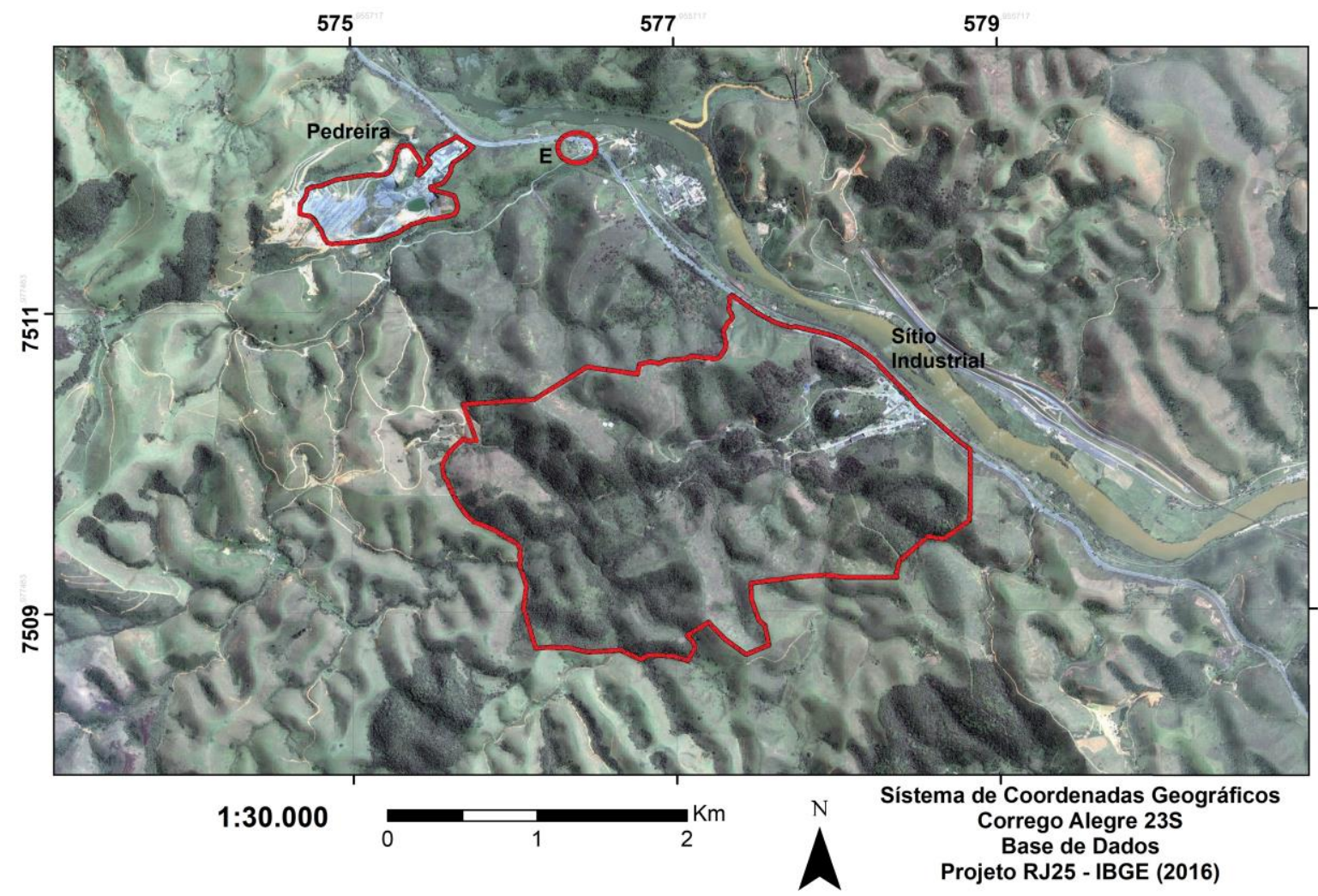

Figura 20: Localização espacial entre pedreira, ponto $\mathrm{E}$ e sítio industrial.

Foram empregados métodos distintos de amostragem para a pedreira Pombal e a unidade industrial, devido às diferentes condições de exposição de rocha encontradas. Na pedreira a técnica de amostragem por scanlines foi utilizada em afloramentos de rocha fresca com grande amplitude horizontal. $\mathrm{Na}$ unidade industrial, a amostragem estrutural foi feita pontualmente, devido à ausência de exposições contínuas de rocha.

\subsubsection{Tipos litológicos}

$\mathrm{Na}$ pedreira os afloramentos estão dispostos em bancadas de desmonte de rocha, com grande abrangência espacial. A rocha no local (Figura 21) apresenta duas variações litológicas principais: um gnaisse ortoderivado de 
granulação fina, que compõe o maior volume formador da rocha; e um migmatito com aparições pontuais. Também foram observados enclaves máficos e porções pegmatíticas, com megacristais centimétricos de quartzo, feldspato e biotita.

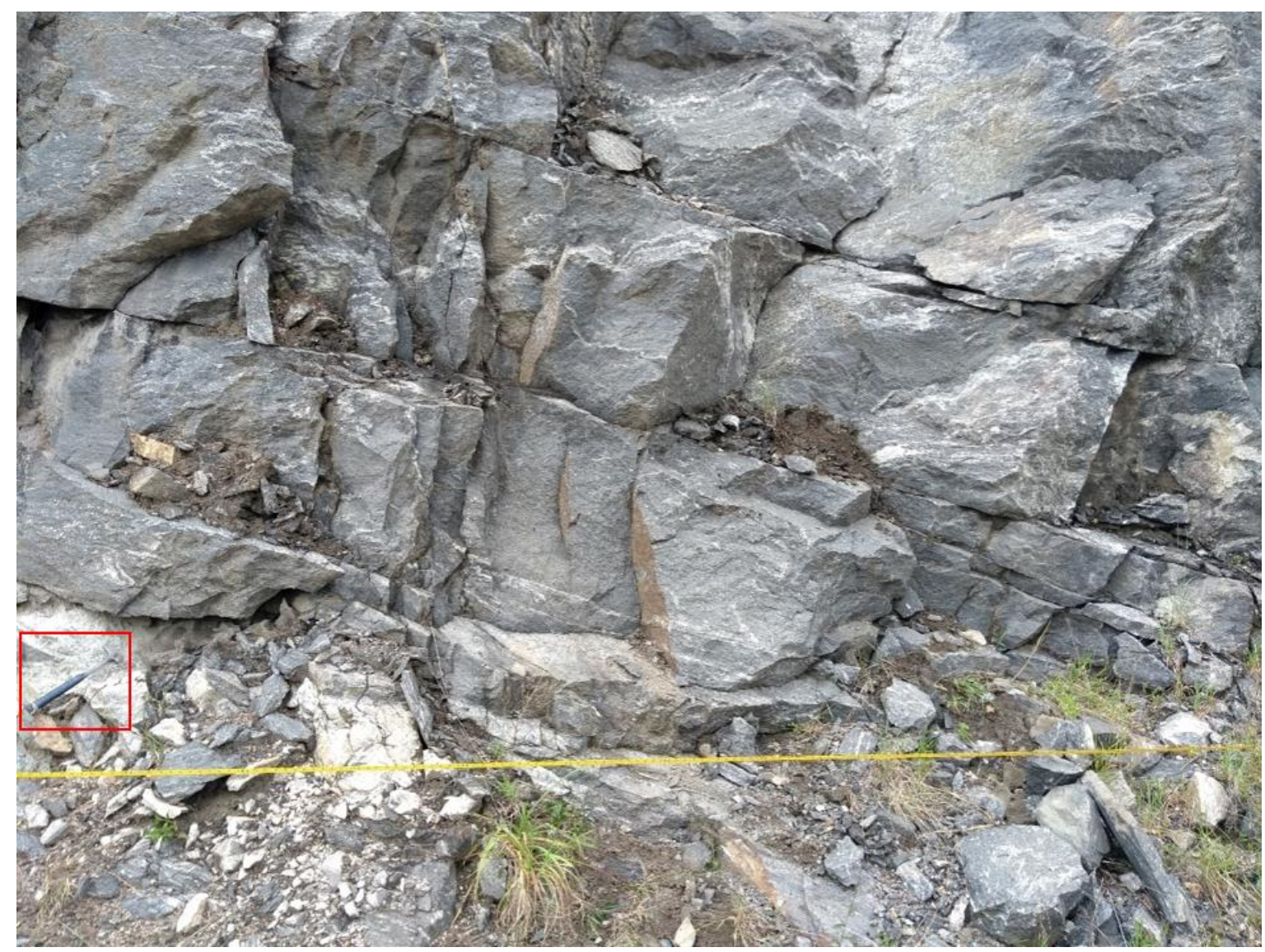

Figura 21: Porção visualmente representativa da rocha observada na pedreira, com martelo para escala no canto inferior esquerdo.

As bandas do gnaisse são milimétricas e sem limites bem definidos, chegando a um centímetro, podendo haver agrupamento de bandas leucocráticas, aumentando sua espessura. O gnaisse é muito fraturado e apresenta muitos veios de quartzo preenchendo fraturas, que podem aparecer associados a óxidos avermelhados, que formam uma película entre o veio e a rocha. Outras fraturas apresentam indícios de hidrotermalismo, e estão preenchidas por cristais de quartzo recobertos por minerais acobreados. Os veios de óxidos e hidrotermais (Figura 22) tem cerca de $5 \mathrm{~mm}$ ou menos, e preenchem fraturas com grande distribuição espacial, chegando a aparecer da base ao topo de bancadas com até 25 metros de altura. 


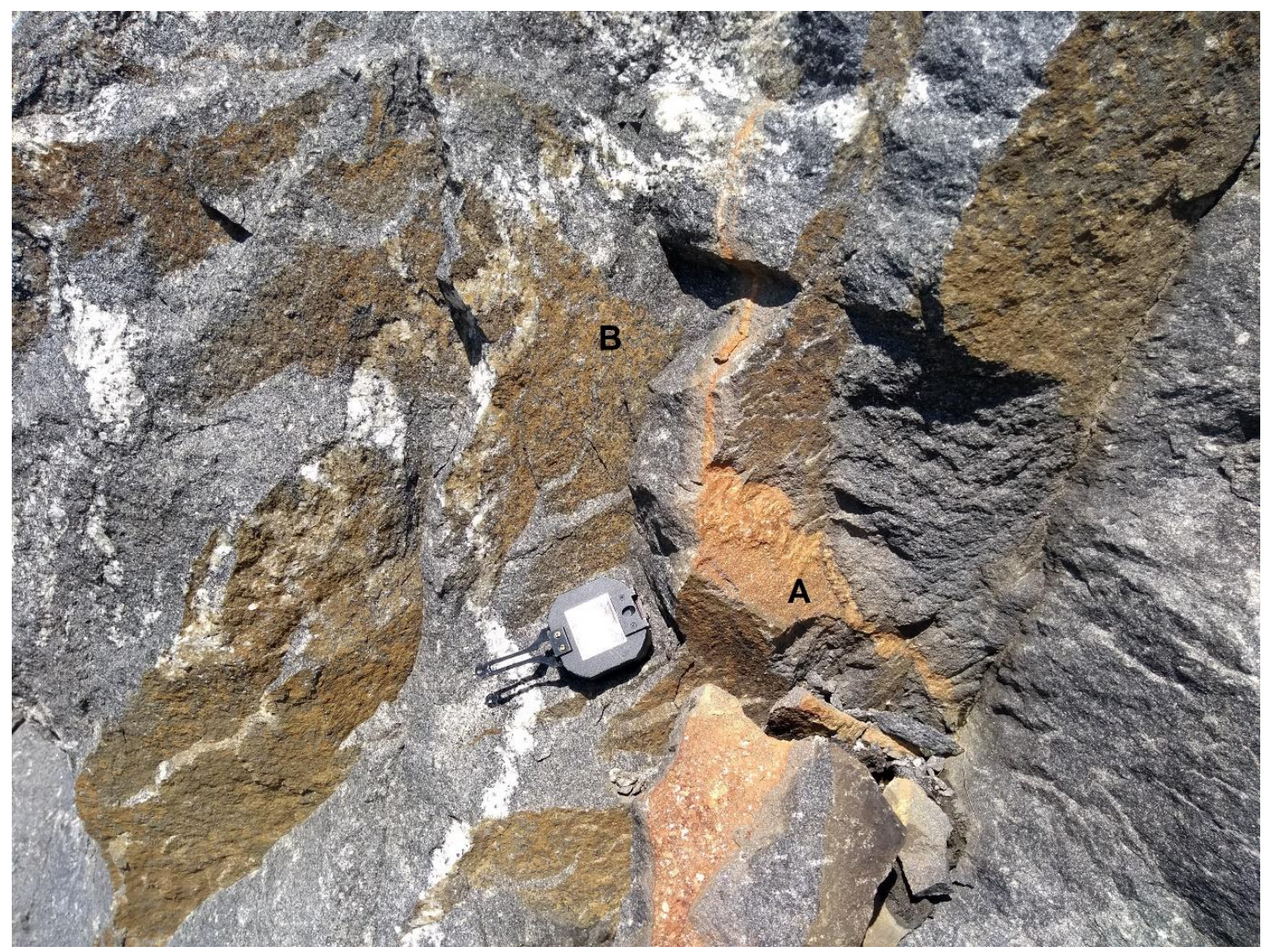

Figura 22: Detalhe de fraturas preenchidas por veios de quartzo, recobertos por cristais formados por hidrotermalismo (A) e oxidação (B).

O migmatito aparece com muitas porções de leucossoma e melanossoma, sendo o volume de leucossoma expressivamente maior, formando bolsões decimétricos que percolam pela rocha, truncando camadas da foliação.

Foram observados dois diques de lamprófiro com até 1,5 metro de largura cortando a rocha gnáissica verticalmente, com algumas porções de menor espessura (decimétricos) aparentemente dobradas. Presentes em diversas bancadas da pedreira e também observados no afloramento do ponto $E$, a cerca de $2 \mathrm{~km}$ de distância, esses diques têm grande abrangência espacial. Os diques verticais têm gradação granulométrica, com matriz e megacristais no centro (megacristais de flogopita e cristais de minerais claros) e granulação mais fina nas extremidades.

$\mathrm{Na}$ unidade industrial foram encontrados afloramentos de menores proporções, com alguns metros de extensão horizontal e pouca extensão vertical (até 2 metros). As porções de rocha observadas encontram-se muito intemperizadas, preservando poucas das características litológicas e estruturais (Figura 23). 


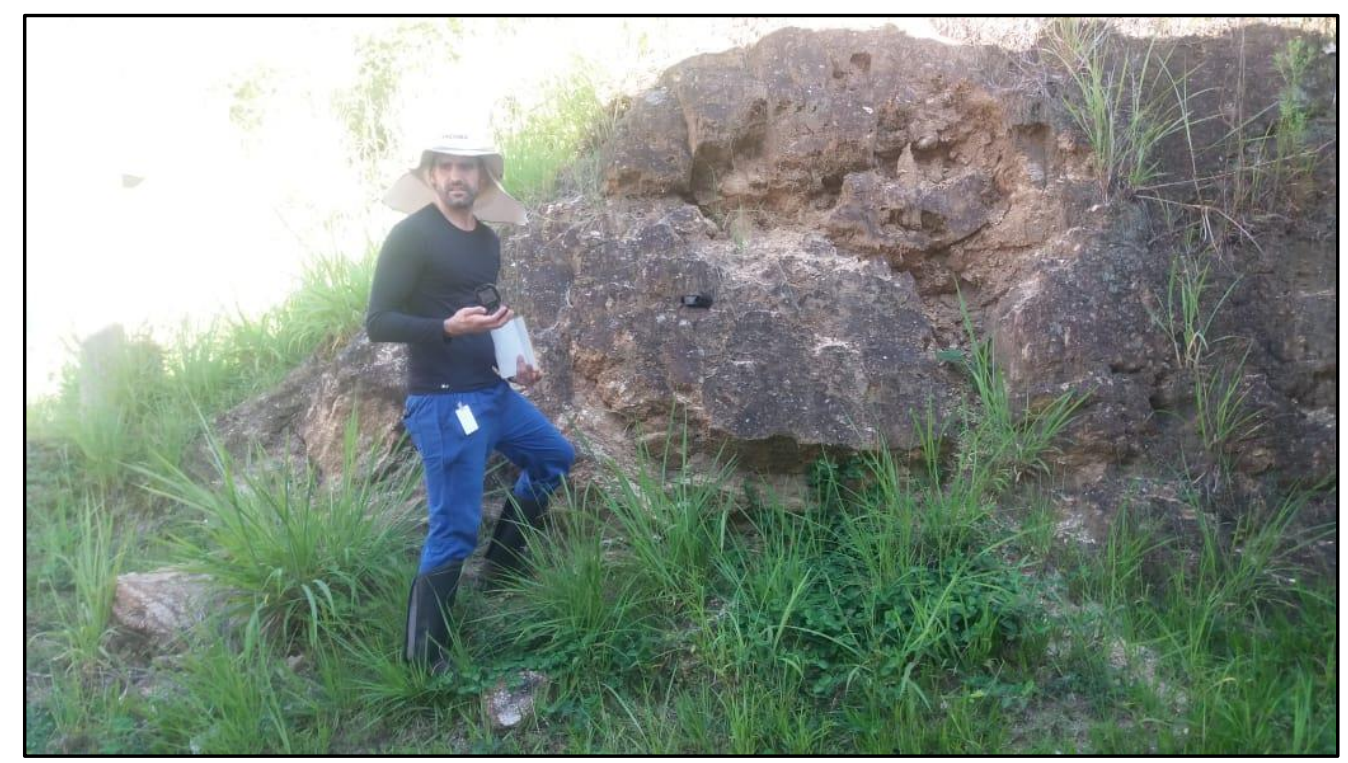

Figura 23: Exemplo de afloramento encontrado na unidade industrial.

As rochas observadas no sítio industrial assemelham-se visualmente a um gnaisse intemperizado. Foi observada uma rocha com foliação bem marcada, provavelmente resquícios de bandas gnáissicas, com grande quantidade de quartzo, alguns cristais de feldspato muito intemperizados e minerais micáceos. Mesmo com porções restritas de afloramento, diversos veios preenchidos por quartzo foram observados.

Com base nas características litológicas-estruturais e na proximidade espacial, interpreta-se que as rochas presentes no sítio industrial e na pedreira fazem parte da mesma unidade litológica, correspondente ao Complexo Juiz de Fora, com competências semelhantes e mesmo histórico tectônico, representando um mesmo domínio tectônico.

Essa unidade é paleoproterozoica e tem histórico evolutivo complexo, envolvendo, pelo menos, dois pulsos metamórficos de alto grau e intenso processo de milonitização. Litologicamente essa unidade é representada na região por ortogranulitos de composição variada até hornblenda gnaisses bandados, sendo o último presumivelmente a rocha observada em campo. 


\subsubsection{Dados estruturais}

A amostragem na pedreira foi realizada por meio de dezesseis scanlines na área da mina e uma scanline em um local adjacente (Figura 24Erro! Fonte de referência não encontrada.), denominado Ponto $E$. Ao todo foram amostradas 179 fraturas.
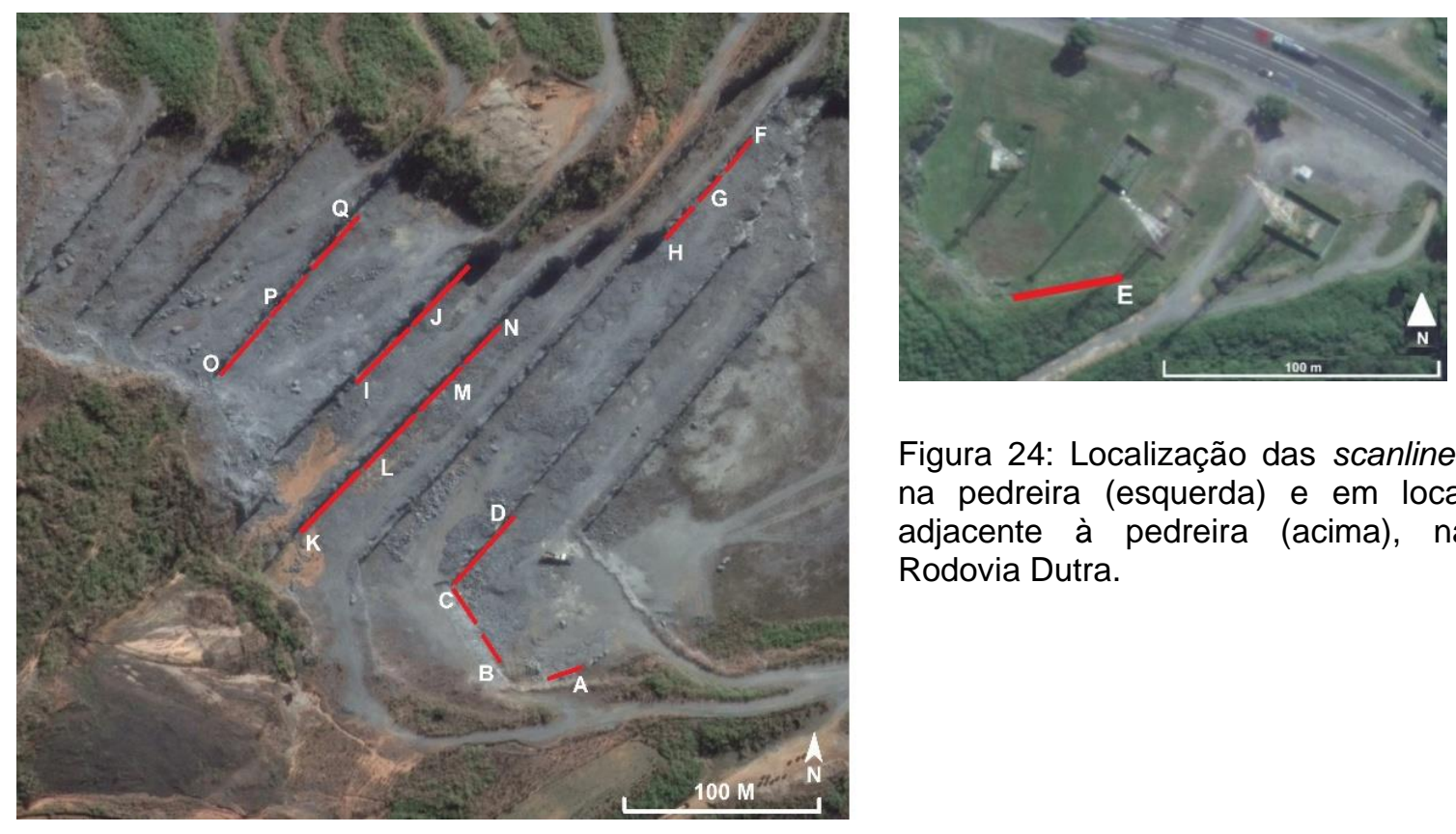

Figura 24: Localização das scanlines na pedreira (esquerda) e em local adjacente à pedreira (acima), na Rodovia Dutra.

As medidas das estruturas realizadas na pedreira foram tratadas e as atitudes das fraturas foram plotadas em um estereograma (Figura 25) por meio do software OpenStereo, com o intuito de observar aglomerações de pontos com atitudes semelhantes, representando, portanto, fraturas de um mesmo grupo. 0 estereograma apresenta os dados já corrigidos pelo método de Terzaghi (1965), que auxilia na correção do viés de orientação. Para efeito de comparação, também é apresentado um estereograma sem a correção.

Ao todo foram identificados três grupos de fraturas: (1) horizontais com atitudes dispersas; (2) fraturas NW-SE de alto ângulo de mergulho; (3) fraturas ENE-WSW de alto ângulo de mergulho. Observa-se que o segundo grupo de fraturas (NW-SE) corresponde, em relação à orientação espacial, aos lineamentos NW (vermelho), enquanto o terceiro grupo (ENE-WSW) corresponde aos lineamentos ENE (rosa). Ao aplicar o método de Terzaghi (1965), o grupo de fraturas horizontais desaparece do estereograma. Isso ocorre pois as estruturas 
horizontais ficam na zona de $20^{\circ}$ em relação às scanlines, que também tem orientação horizontal.

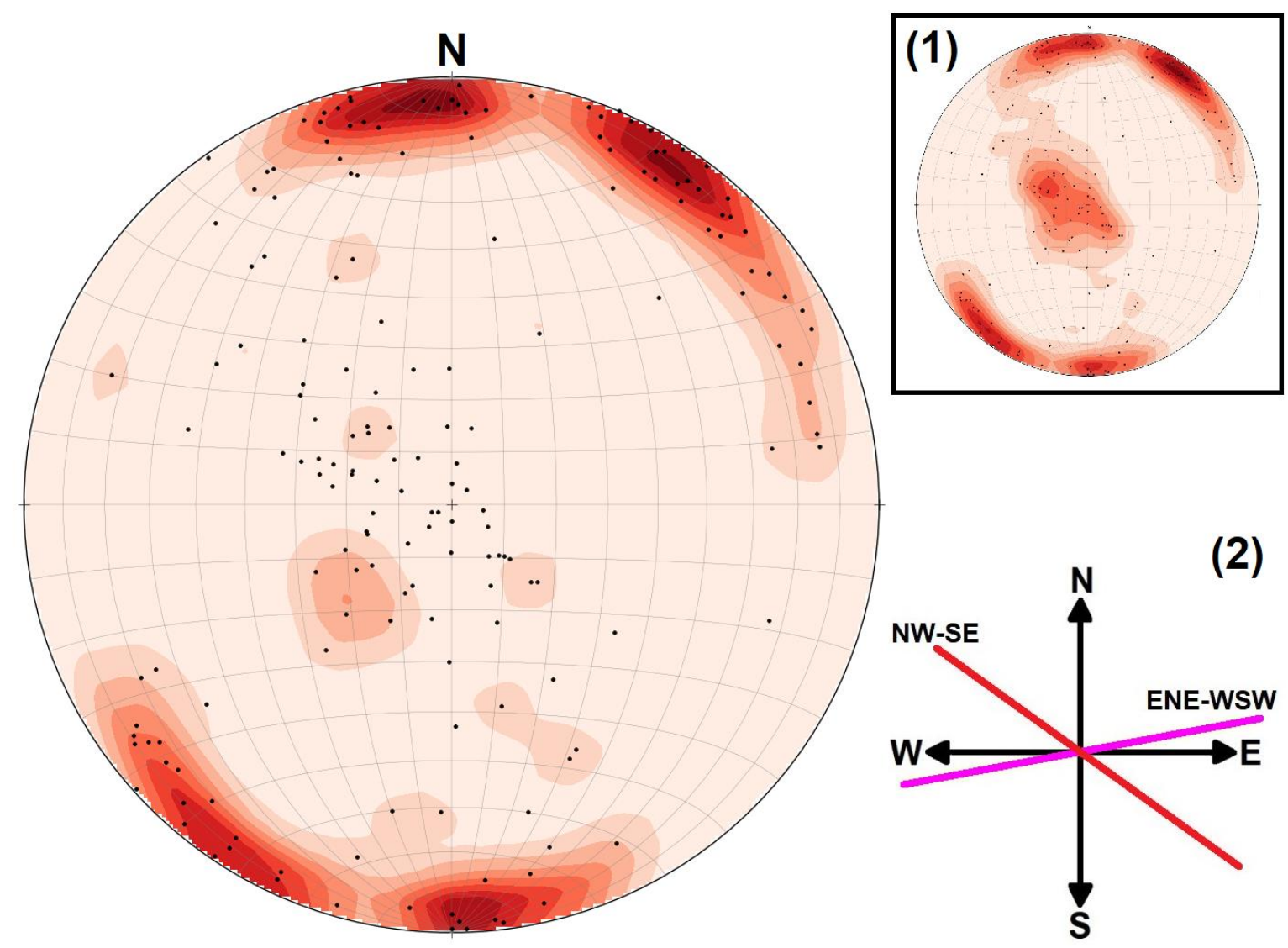

Figura 25: Estereograma representativo dos polos das fraturas amostradas na pedreira e no ponto E, totalizando 179 estruturas. Detalhes (1) de estereograma menor, representando os dados sem correção de Terzaghi (1965) e (2) de grupos de fraturas subverticais, associados por cor aos grupos de lineamentos espacialmente correlacionados.

A amostragem de fraturas na unidade industrial foi realizada em seis pontos aflorantes dentro da planta industrial, medindo um total de 49 estruturas. O alto grau intempérico das rochas e as dimensões limitadas dos afloramentos impossibilitaram a caracterização detalhada das fraturas amostradas. As atitudes medidas foram plotadas em um estereograma (Figura 26) como polos de fratura utilizando o software OpenStereo, com o intuito de observar, assim como na pedreira, aglomerações de pontos, correspondentes a grupos de fraturas.

Foram identificados dois grupos de fraturas, (1) fraturas NW-SE de alto ângulo de mergulho; (2) fraturas NNW-SSE de alto ângulo de mergulho. A ausência de fraturas horizontais (no centro do estereograma) é, supostamente, efeito da limitada extensão vertical dos afloramentos observados. 


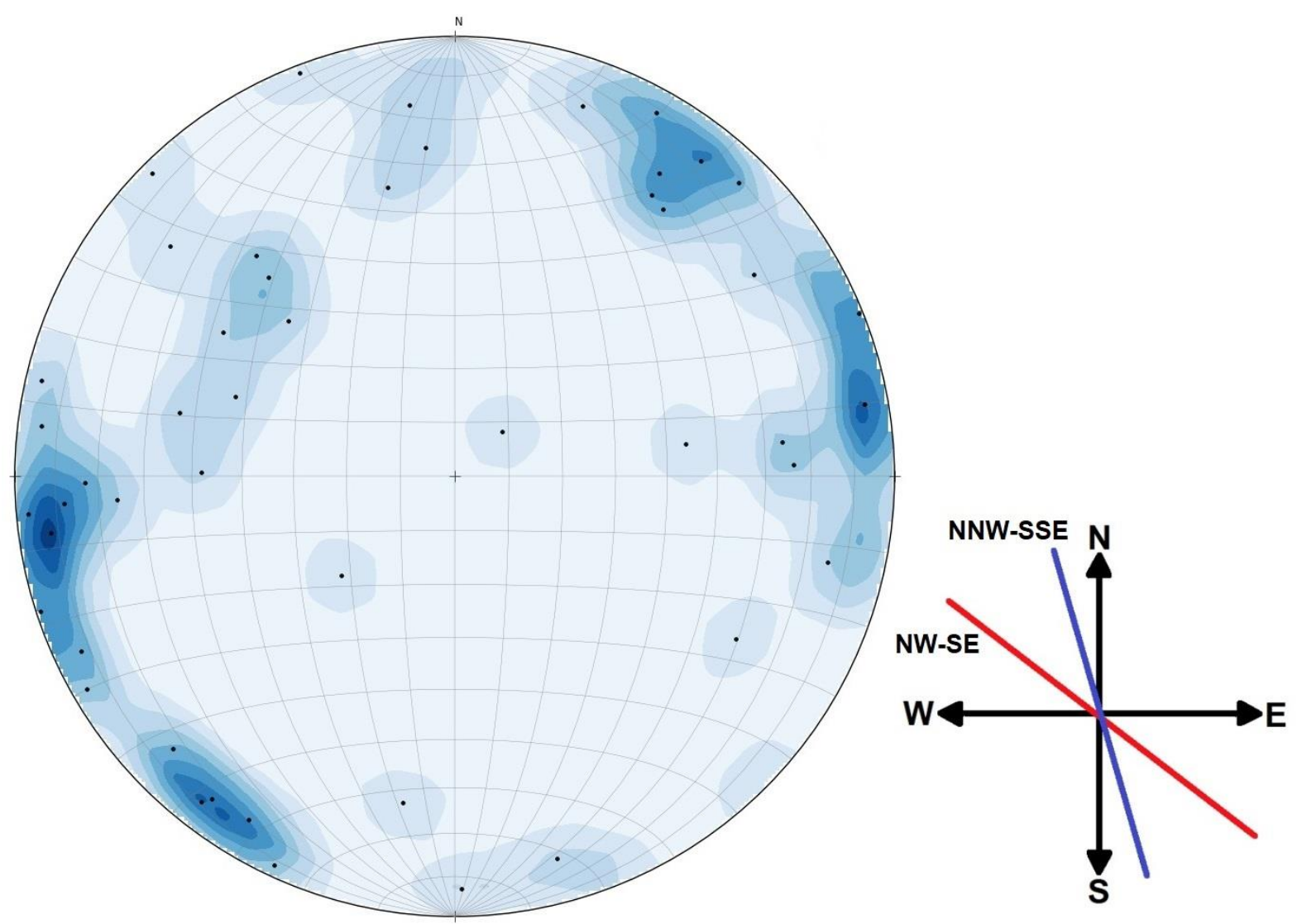

Figura 26: Estereograma representativo dos polos das fraturas amostradas nos seis pontos aflorantes da unidade industrial, com detalhe de grupos de fraturas subverticais, associados por cor aos grupos de lineamentos espacialmente correlacionados.

O produto principal da análise dos grupos de fraturas é o quadro comparativo apresentado na Figura 27, que exibe o resumo dos dados qualitativos e quantitativos coletados para todas as fraturas observadas. São apresentados 0 número de descontinuidades observadas para cada grupo, os intervalos e os valores médios de direção e mergulho, o espaçamento médio, calculado com base nas medições realizadas por meio das scanlines, e morfologia e características particulares de cada um dos três grupos. A Figura 28 apresenta um bloco diagrama com a representação dos três grupos de fraturas, possibilitando a melhor visualização da disposição espacial entre os grupos. 


\begin{tabular}{|c|c|c|c|c|}
\hline Grupo & Direção & Mergulho & Estereograma & Espaçamento, Morfologia, Comprimento e Caracterização \\
\hline $\begin{array}{c}1(\mathrm{H}) \\
56 \text { fraturas }\end{array}$ & $\begin{array}{l}\text { Média } \\
\text { N75E }\end{array}$ & $\begin{array}{l}\text { Média } \\
19^{\circ}\end{array}$ & & $\begin{array}{l}\text { Espaçamento médio de 1,36 metro; espaçamento entre fraturas relativamente } \\
\text { heterogêneo, com aglomerações em algumas camadas horizontas. } \\
\text { Morfologia: planas a curvas; família com mais casos de ondulação e curvatura; } \\
\text { Comprimento: algumas fraturas estão entre as mais extensas, entretanto o } \\
\text { comprimento médio é o menor entre os grupos, com cerca de } 6 \text { metros; } \\
\text { Características: grupo com maior indícios de campo para a presença de fluxo; } \\
\text { maior número de fraturas com água e/ou vegetação e casos de bordas de fraturas } \\
\text { com rocha intemperizada. }\end{array}$ \\
\hline $\begin{array}{l}2 \text { (NW-SE) } \\
55 \text { fraturas }\end{array}$ & $\begin{array}{l}\text { Média } \\
\text { N42W }\end{array}$ & $\begin{array}{c}68^{\circ}-90^{\circ} \text { para } \\
\text { NE ou SW }\end{array}$ & & $\begin{array}{l}\text { Espaçamento médio de 1,04 metro; espaçamento entre fraturas relativamente } \\
\text { homogêneo. } \\
\text { Morfologia: majoritariamente planas, poucas onduladas; } \\
\text { Comprimento: 8,55 metros, maior comprimento médio entre os grupos, apesar } \\
\text { de apresentar terminações fora da parede; } \\
\text { Características: alta frequência de fraturas preenchidas por veios de quartzo, que } \\
\text { forma um filme branco em fraturas abertas; associação de veios à óxidos, o que } \\
\text { caracteriza atividade hidráulica recente, indicativo de fluxo. Destaque para a } \\
\text { presença de fraturas preenchidas por veios de quartzo com cristais recobertos } \\
\text { por minerais abronzeados, com origem hidrotermal. }\end{array}$ \\
\hline $\begin{array}{c}3 \text { (ENE-WSW) } \\
41 \text { fraturas }\end{array}$ & $\begin{array}{l}\text { N79-90W } \\
\text { e N50-90W }\end{array}$ & $\begin{array}{l}69^{\circ}-89^{\circ} \text { para } \\
\text { NNW ou SSE }\end{array}$ & & $\begin{array}{l}\text { Espaçamento médio de 4,94 metros; espaçamento entre fraturas relativamente } \\
\text { homogêneo. } \\
\text { Morfologia: majoritariamente planas, poucas onduladas; maior rugosidade entre } \\
\text { os grupos; } \\
\text { Comprimento: média de 8,04 metros, apresentando muitas terminações fora da } \\
\text { parede; } \\
\text { Características: alta frequência superfícies revestidas por filme branco de } \\
\text { quartzo, resquícios de fraturas preenchidas por veios de quartzo. Esse grupo } \\
\text { também apresenta fraturas intrudidas por diques de lamprófiro. }\end{array}$ \\
\hline
\end{tabular}

Figura 27: Quadro comparativo com os três grupos de fraturas observados na pedreira e ponto E. 


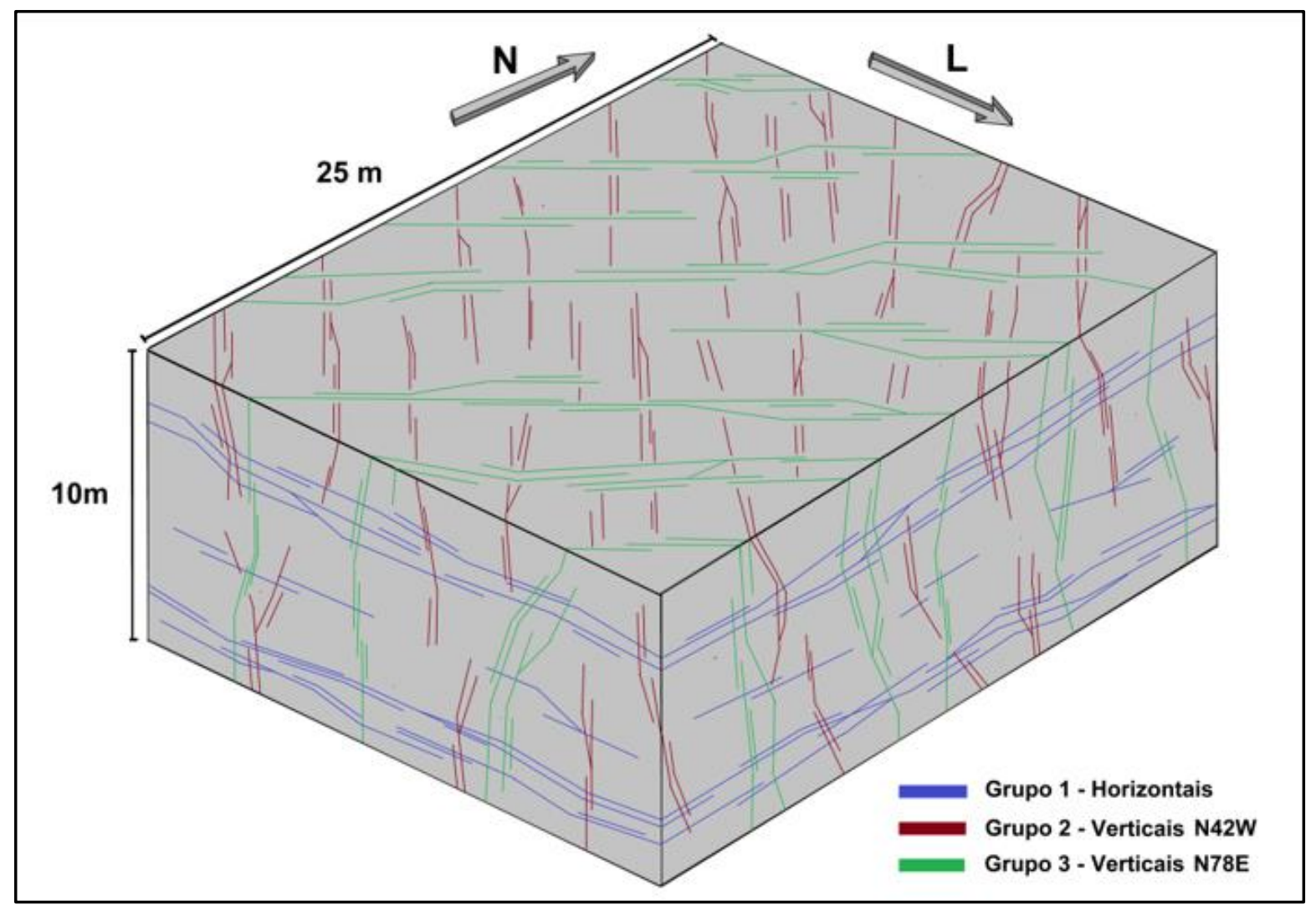

Figura 28: Bloco diagrama com o modelo conceitual de disposição espacial dos três grupos de fraturas identificados para a Pedreira (a partir da análise de lineamentos e da amostragem estrutural por scanlines).

\subsection{Levantamentos geofísicos}

A técnica de caminhamento elétrico gerou dezesseis perfis geoelétricos 2D (Figura 29). No geral as unidades geoelétricas são observadas nos perfis com a seguinte classificação:

- Unidade geoelétrica com altos valores de eletrorresistividade (acima de 200 $\Omega \mathrm{m}$ ), representada em tons laranja e avermelhados, interpretada como solo seco, em superfície, ou rocha fresca, em profundidade;

- Unidade geoelétrica com valores intermediários de eletrorresistividade (100 a $200 \Omega \mathrm{m}$ ), em amarelo e marrom, correlaciona-se a material oriundo de alteração de rocha, representando uma zona de transição;

- Unidade geoelétrica com baixos valores de eletrorresistividade (inferior a 60 $\Omega \mathrm{m}$ ), azul escura a esverdeada, aparece em superfície devido ao solo úmido, ou em camadas mais profundas, interpretada como zonas saturadas. 


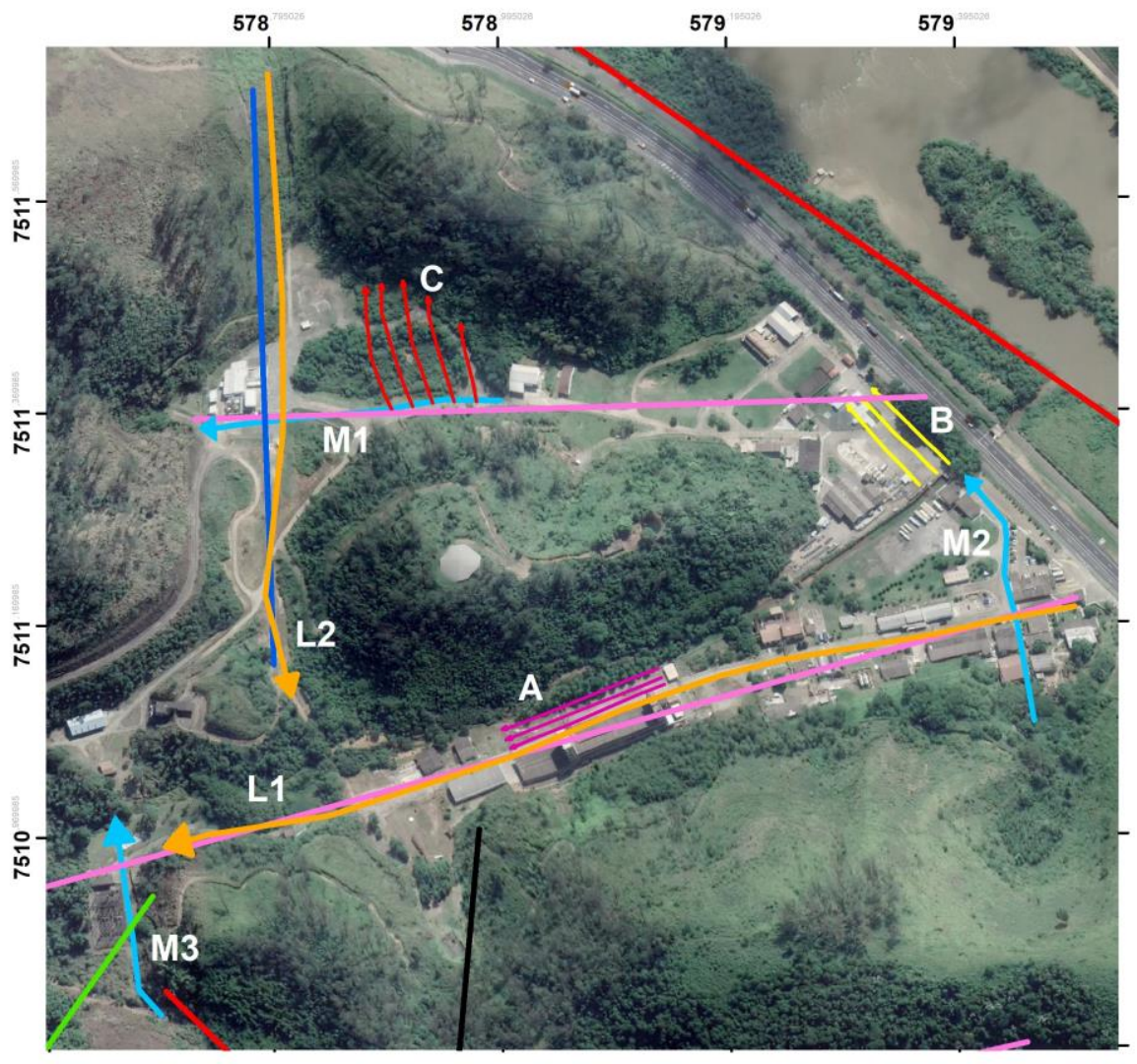

\section{LEGENDA}

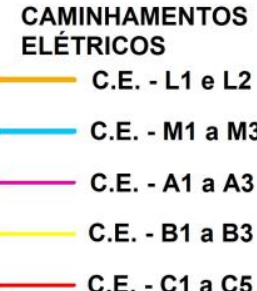

\section{LINEAMENTOS} WNW

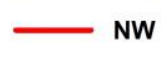

$\longrightarrow$ NNW
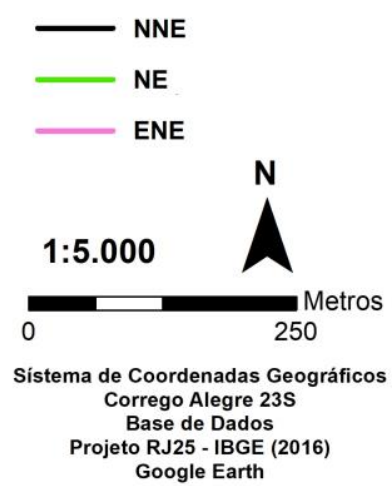

Figura 29: Mapa do sítio industrial com localização dos perfis de caminhamento elétrico e dos lineamentos traçados.

Os perfis apresentam no geral feições complexas, com muitos corpos resistivos de menores dimensões (2 a 6 metros), sugerindo zonas de falhas ou fraturas. Porções com altos valores de eletrorresistividade, da ordem de centenas de Ohm x metro, são observadas em vermelho escuro, e são dominantes em vários perfis.

São comuns corpos de formato esferoidal com valores de eletrorresistividades relativamente médios a elevados, que representam possíveis matacões, material de aterro ou material seco de composição arenosa, associado a depósitos aluvionares do Rio Paraíba do Sul. Valores baixos de eletrorresistividade também podem estar associados a interferências por tubulações e aterramentos de equipamentos elétricos, configurando uma limitação do método geoelétrico.

As técnicas de sísmica de refração e de prova MASW geraram respectivamente oito e seis perfis interpretativos (Figura 13), fornecendo subsídios à melhor compreensão do comportamento do substrato rochoso (EEG, 2017). 
Para cada um dos perfis de refração, quatro informações principais são apresentadas: (1) gráfico de sobreposição de dromócronas, que são medidas de velocidade empregadas na estimativa de confiabilidade do modelo; (2) gráfico ilustrativo dos percursos efetivos dos raios sísmicos em subsolo, demonstrando a precisão da profundidade investigada; (3) modelo das velocidades sísmicas reais (ondas P); (4) modelo das velocidades sísmicas interpretadas. Para os perfis do método MASW, são apresentados um sismograma obtido pela modelagem das velocidades registradas e um modelo de velocidades sísmicas.

Os perfis sísmicos obtidos indicaram que o sítio apresenta uma relativa homogeneidade estratigráfica, com a média de profundidade do topo rochoso em $10 \mathrm{~m}$. Há uma cobertura superficial caracterizada por baixas velocidades sísmicas, entre 1000 a $1200 \mathrm{~m} / \mathrm{s}$ para as ondas P e 600 a 800 m/s para as ondas S. Material de aterro, coberturas coluvionares e depósitos inconsolidados são observados nessa primeira camada. $O$ topo do embasamento é identificado por maiores velocidades das ondas sísmicas, $1800 \mathrm{~m} / \mathrm{s}$ para as ondas P e cerca de $1000 \mathrm{~m} / \mathrm{s}$ para as ondas S.

Devido ao modelo contínuo de velocidade empregado, é possível observar a faixa de transição entre as camadas superiores e o substrato rochoso, a qual é correlacionada a uma camada estreita de material rochoso alterado. Formas irregulares no modelo de velocidade sugerem a presença de aglomerados de matacões, e lateralmente variações verticais e bruscas são interpretadas como falhas. Uma interpretação combinada das técnicas geofísicas é apresentada a seguir para cada perfil investigado.

- Perfil L1 - Paralelo ao Córrego

As técnicas de caminhamento elétrico e sísmica de prova MASW foram executadas ao longo do vale do córrego (Perfil L1), por sobre a via existente no local. Os percursos das duas técnicas são semelhantes, numa extensão de 800 $\mathrm{m}$, tendo o seu início referido à área próxima da Portaria da unidade industrial (Figura 12 e Figura 13).

A Figura 3030 apresenta os resultados combinados das técnicas de prova MASW (sismograma) e do caminhamento elétrico para o local. Os dois perfis estão posicionados no mesmo local e em escalas semelhantes. A investigação alcançou profundidades na ordem de 70 metros na técnica de caminhamento elétrico e de cerca de 20 metros para o MASW. 


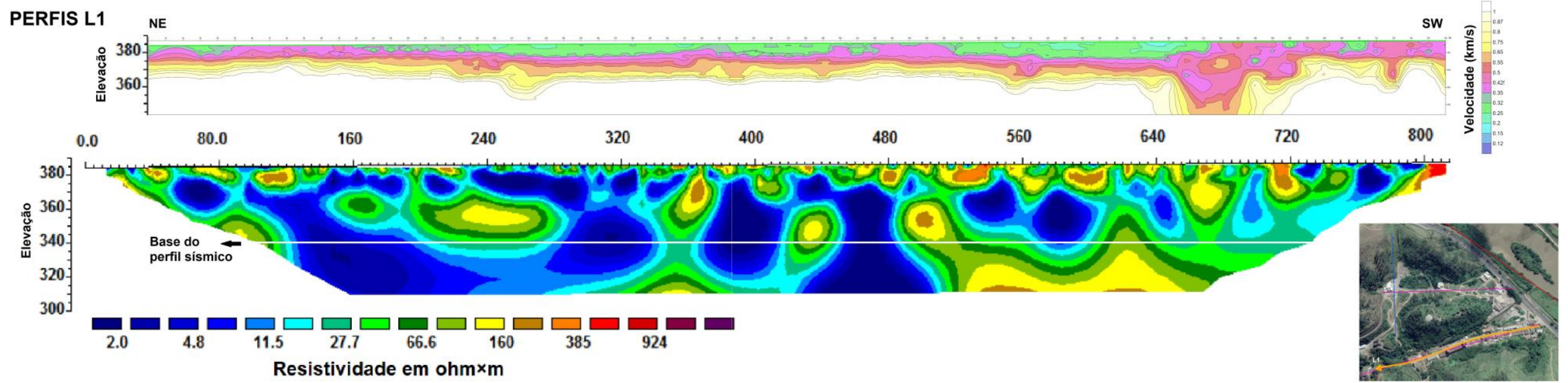

Figura 30: Resultados de sísmica de prova MASW (acima) e resistividade por caminhamento elétrico (abaixo) do perfil L1. 
O caminhamento elétrico resultou em valores baixos de eletrorresistividade, mesmo em cotas que alcançam $310 \mathrm{~m}$ (mais de 70 metros de profundidade), possivelmente por se posicionar por sobre uma superfície de fratura, o que é corroborado pelo paralelismo entre este perfil L1 e um dos lineamentos observados na unidade industrial (Figura 2929). O nível de água não é observável no perfil devido à sua escala, mas interpreta-se que esteja situado em profundidades rasas. Da origem do perfil até os 500 metros, feições esféricas e elipsoides são observadas com valores de eletrorresistividade maiores que o entorno, representando possivelmente zonas esferoidais de rochas menos alteradas. A partir dos 500 metros há uma elevação da resistividade em profundidade, indicando a ocorrência de topo rochoso alterado.

O perfil da prova MASW indica a ocorrência do topo rochoso com relativa uniformidade entre as cotas 360 e $370 \mathrm{~m}$ até a extensão aproximada de $640 \mathrm{~m}$ no perfil (referência do perfil do caminhamento elétrico). Deste ponto até a extensão 720 $\mathrm{m}$, há uma maior variação lateral das velocidades sísmicas das ondas $\mathrm{S}$, interpretado como um espessamento do material rochoso alterado, pela ocorrência de falhas ou zonas de fraturas.

Há baixa correlação dos resultados dos modelos geológicos obtidos com a sísmica e com o caminhamento elétrico neste local. Avalia-se que a técnica do caminhamento elétrico resultou numa melhor indicação das heterogeneidades geológicas do local, além de ter possibilitado a investigação de maiores profundidades.

\section{- Perfil L2 - Oeste da Área Industrial}

As técnicas de caminhamento elétrico e sísmica de prova MASW foram também executadas ao longo do Perfil L2, situado na região a oeste da área industrial, entre a área $C$ até o córrego, numa extensão de $560 \mathrm{~m}$, e no sentido de Norte para Sul (Figura 12 e Figura 13).

A Figura 3131 apresenta os resultados combinados das técnicas de prova MASW (sismograma) e do caminhamento elétrico do Perfil L2. O início do caminhamento elétrico situa-se cerca de $150 \mathrm{~m}$ mais a Norte que o início do perfil de sísmica, que, por sua vez, estende-se por um percurso de 100 metros além daquele do caminhamento elétrico. A investigação alcançou profundidades na ordem de 80 metros pela técnica de caminhamento elétrico e de cerca de 50 metros para o MASW. 
De Norte para Sul, elevados valores de eletrorresistividade são observados da origem do perfil até a posição 260 metros, com manto de intemperismo até 30 metros de profundidade. Entre as posições 260 metros e 360 metros há uma feição vertical com baixos valores de eletrorresistividade, referente ao lineamento posicionado ortogonalmente a este perfil (Figura 299), sobre o qual realizou-se o perfil M1. Trata-se provavelmente de uma zona de fraturamento com maior espessamento do manto de intemperismo. A partir da posição em 360 metros até 500 metros é observado o topo rochoso, com inclinação para norte.

O perfil de prova MASW resultou, no início do perfil, em valores mais elevados das velocidades das ondas S próximo da cota $370 \mathrm{~m}$, coerente com o perfil de caminhamento elétrico, indicando a ocorrência do topo da rocha próxima desta cota. O perfil de prova MASW também se mostrou coerente com os resultados de caminhamento elétrico na porção mais a sul dos perfis, a partir da posição $440 \mathrm{~m}$ do perfil do caminhamento elétrico, onde o topo da rocha sã encontra-se próximo da cota $380 \mathrm{~m}$. 

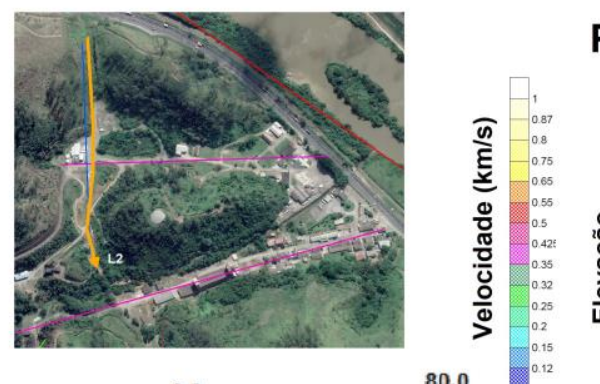

\section{Perfis L2}

NNW

SSE

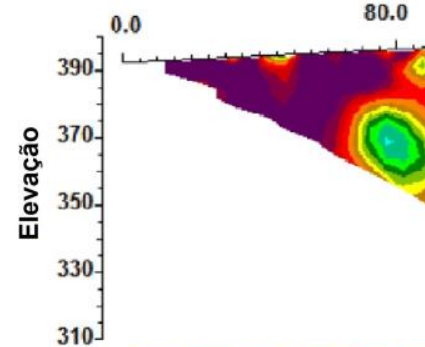

160

40

320

400

480

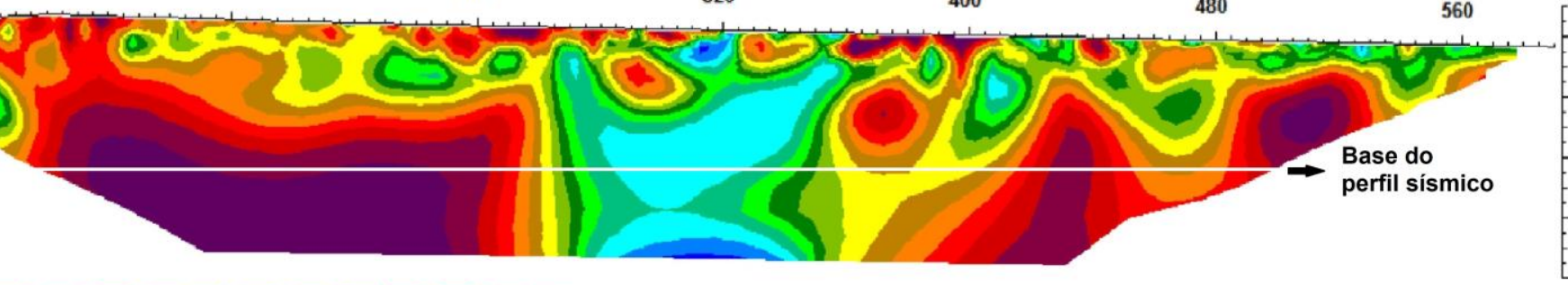

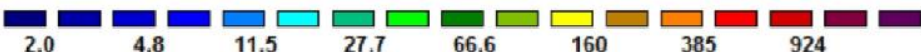

Resistividade em ohm $\times$ m

Figura 31: Resultados de sísmica de prova MASW e resistividade por caminhamento elétrico do perfil L2. 
Avalia-se que a técnica do caminhamento elétrico resultou, mais uma vez, em uma melhor indicação das heterogeneidades geológicas do local, especialmente para a locação da zona de fraturamento entre as posições $260 \mathrm{e}$ $360 \mathrm{~m}$ do perfil, além de ter possibilitado a investigação de porções mais profundas do meio subterrâneo. De acordo com a Figura 299, um lineamento NNW foi observado ocorrendo de forma paralela ao Perfil L2. Entretanto, ao contrário do que foi obtido no Perfil L1 de caminhamento elétrico, o Perfil L2 mostrou a predominância de rochas mais resistivas (não fraturadas) no local.

- Perfis M1, M2 e M3

Os perfis M1, M2 e M3 são caminhamentos elétricos de extensão média, executados em diversos locais da área industrial (Figura 299). O Perfil M1 foi executado no sentido de leste para oeste (Figura 322), próximo à área $\mathrm{C}$, numa extensão de $220 \mathrm{~m}$ e alcançando profundidades de cerca de 30 metros.

No M1 são observados corpos resistivos em porções rasas e por toda a extensão do perfil, que podem ser associados a material de aterro, como constatado em campo. A estrutura mais marcante é uma zona de baixos valores de eletrorresistividade, localizada aproximadamente em 175 metros, correspondendo ao lineamento de direção N-S paralelo ao perfil de caminhamento elétrico L2.

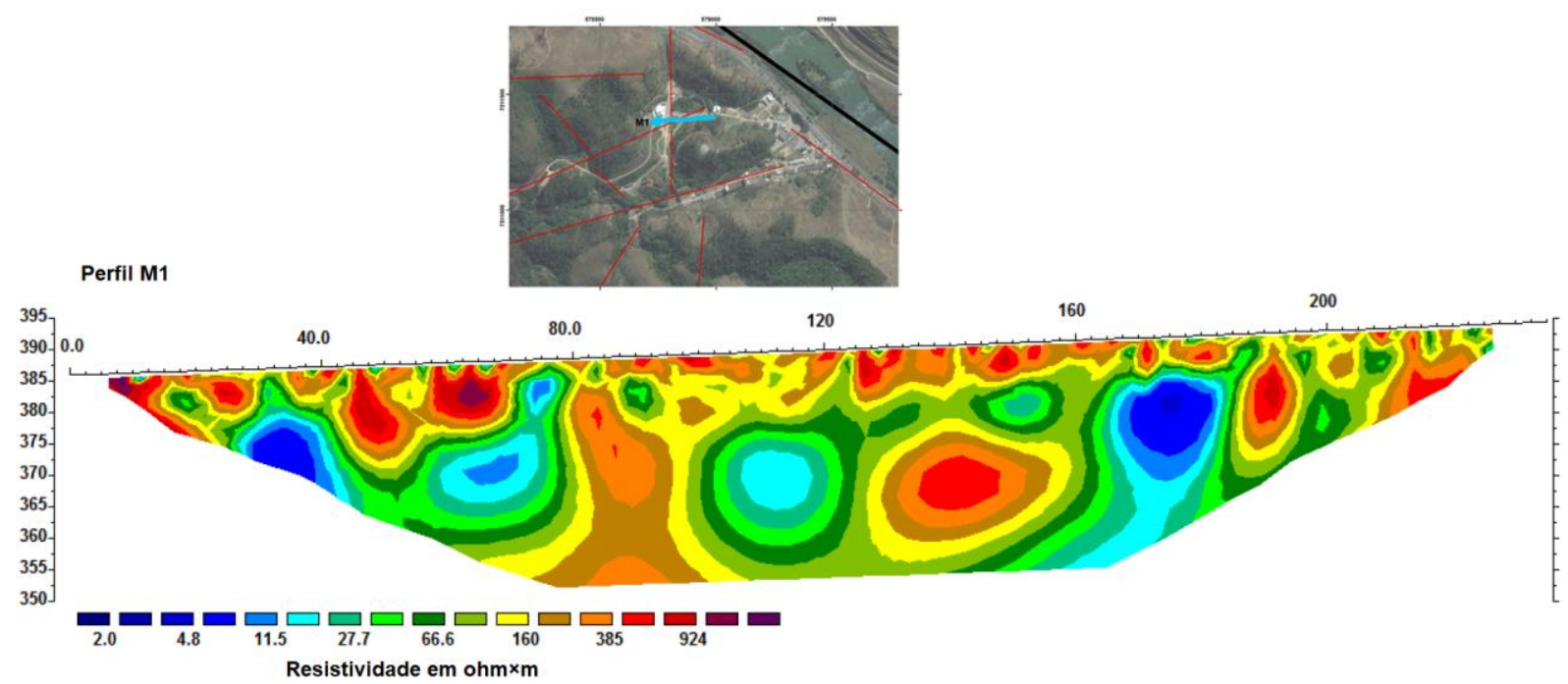

Figura 32: Resultados de resistividade do perfil M1 de caminhamento elétrico. 
O Perfil M2 foi executado próximo à área da portaria no sentido de sul para norte (Figura 333), numa extensão de $230 \mathrm{~m}$ e alcançando profundidades de cerca de 40 metros.

Predominam materiais de resistividade relativamente baixa em todo o perfil. Da origem M2 do perfil até cerca de 80 metros, corpos relativamente resistivos são observados em profundidades rasas, correspondentes provavelmente à rocha alterada. Entre 80 e 120 metros é observada uma grande seção com baixos valores de eletrorresistividade, representativa do lineamento associado ao vale do córrego, sobre o qual executou-se o perfil L1.

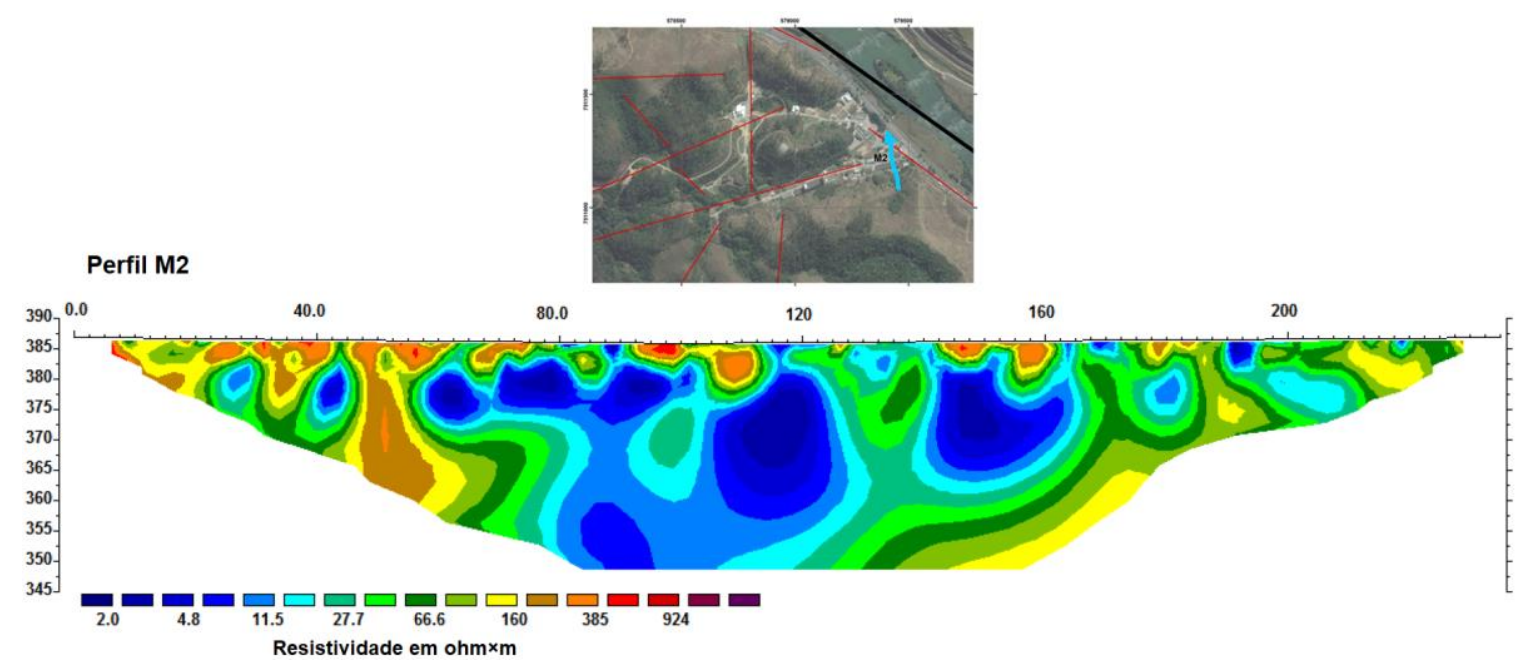

Figura 33: Resultados de resistividade do perfil M2 de caminhamento elétrico.

O Perfil M3 foi executado próximo à área de captação de água e da estação elétrica, no sentido de sul para norte (Figura 344), numa extensão de 170 $\mathrm{m}$ e alcançando profundidades de cerca de $40 \mathrm{~m}$.

O ponto inicial do perfil está em uma área elevada, com rochas próximas à superfície, representando um substrato com altos valores de eletrorresistividade até os 50 metros do perfil. Entre 50 e 120 metros o perfil apresenta baixos valores de eletrorresistividade, representando uma estrutura de orientação NE-SW que intercepta o perfil. Na porção final do perfil, onde ocorre a intersecção com o lineamento paralelo ao perfil L1, aproximadamente em 140 metros, é observada uma segunda zona de baixa eletrorresistividade. 


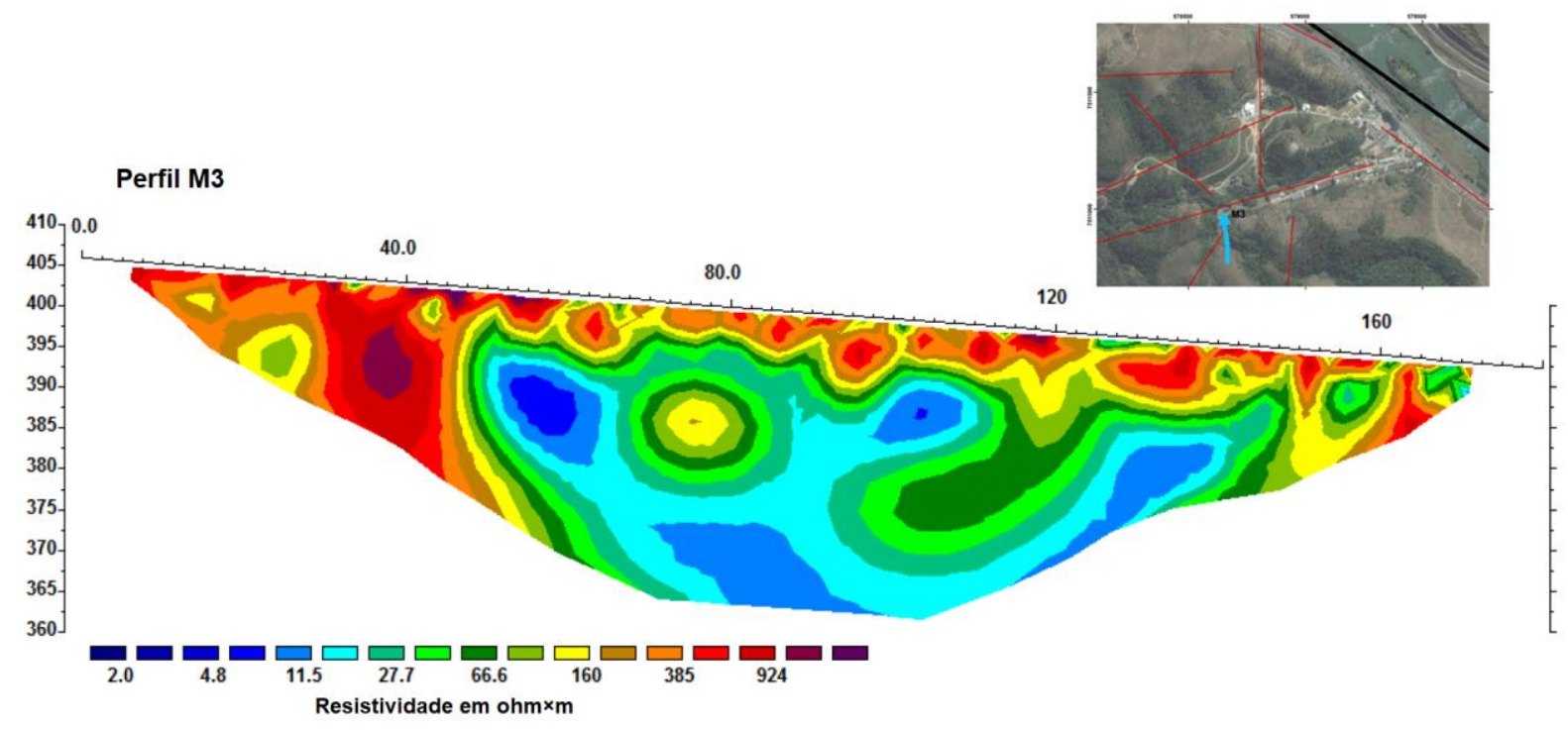

Figura 34: Resultados de resistividade do perfil M3 de caminhamento elétrico.

- Área A

Três perfis paralelos de caminhamento elétrico (identificados como A1, A2 e A3), e outros três perfis paralelos de sísmica de refração (identificados como LDA1, LDA2 e LDA3) foram executados na área aberta defronte ao prédio principal da Área A, cobrindo uma mesma área de 140 por 20 metros (Figura 299).

As Figuras 35, 36 e 37 apresentam os resultados comparados dos perfis de sísmica de refração e de caminhamento elétrico. As investigações alcançaram aproximadamente 20 metros de profundidade para ambos os métodos. 


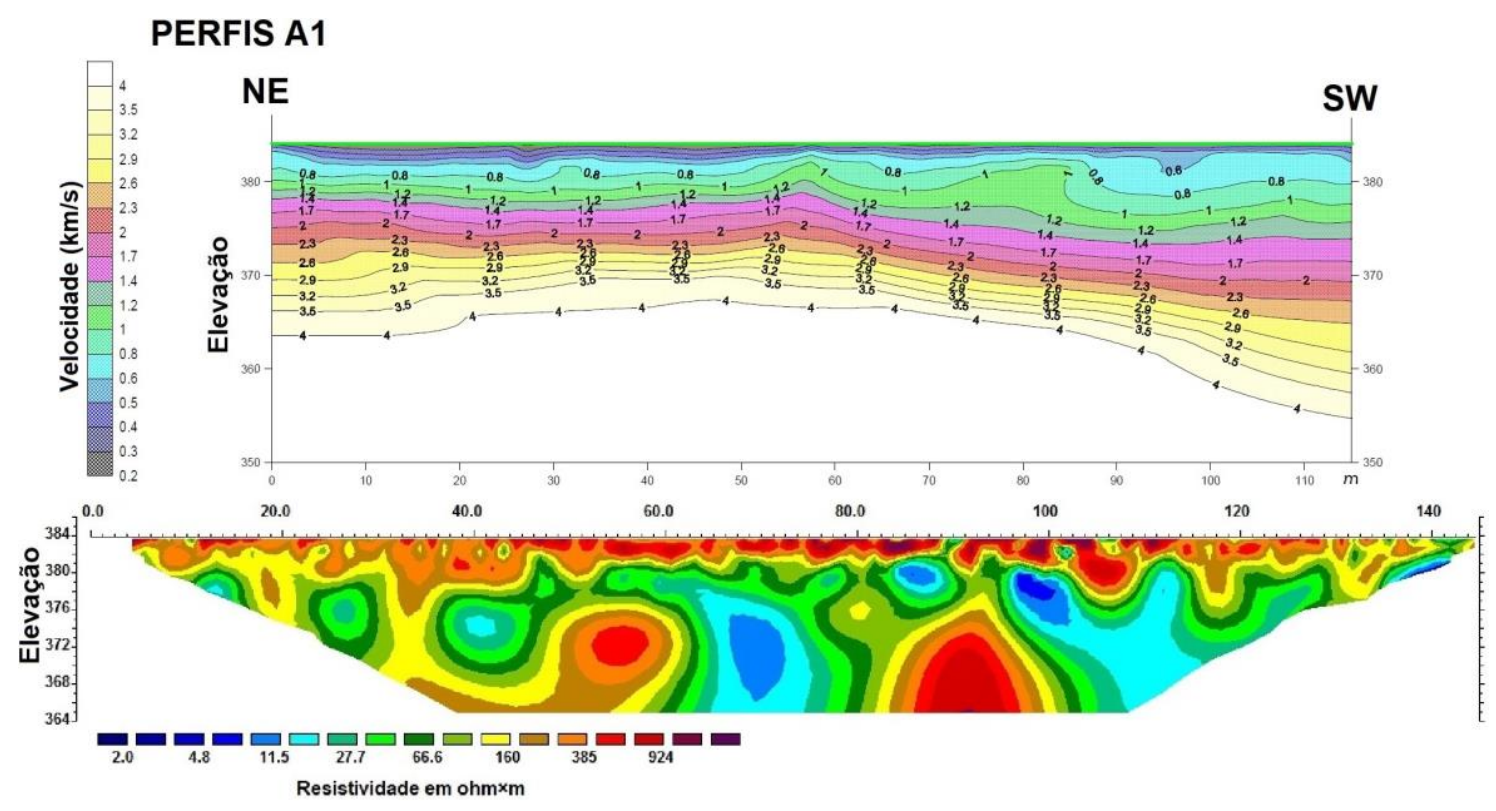

Figura 35: Perfis A1 de sísmica de refração (acima) e caminhamento elétrico (abaixo) da Área A.

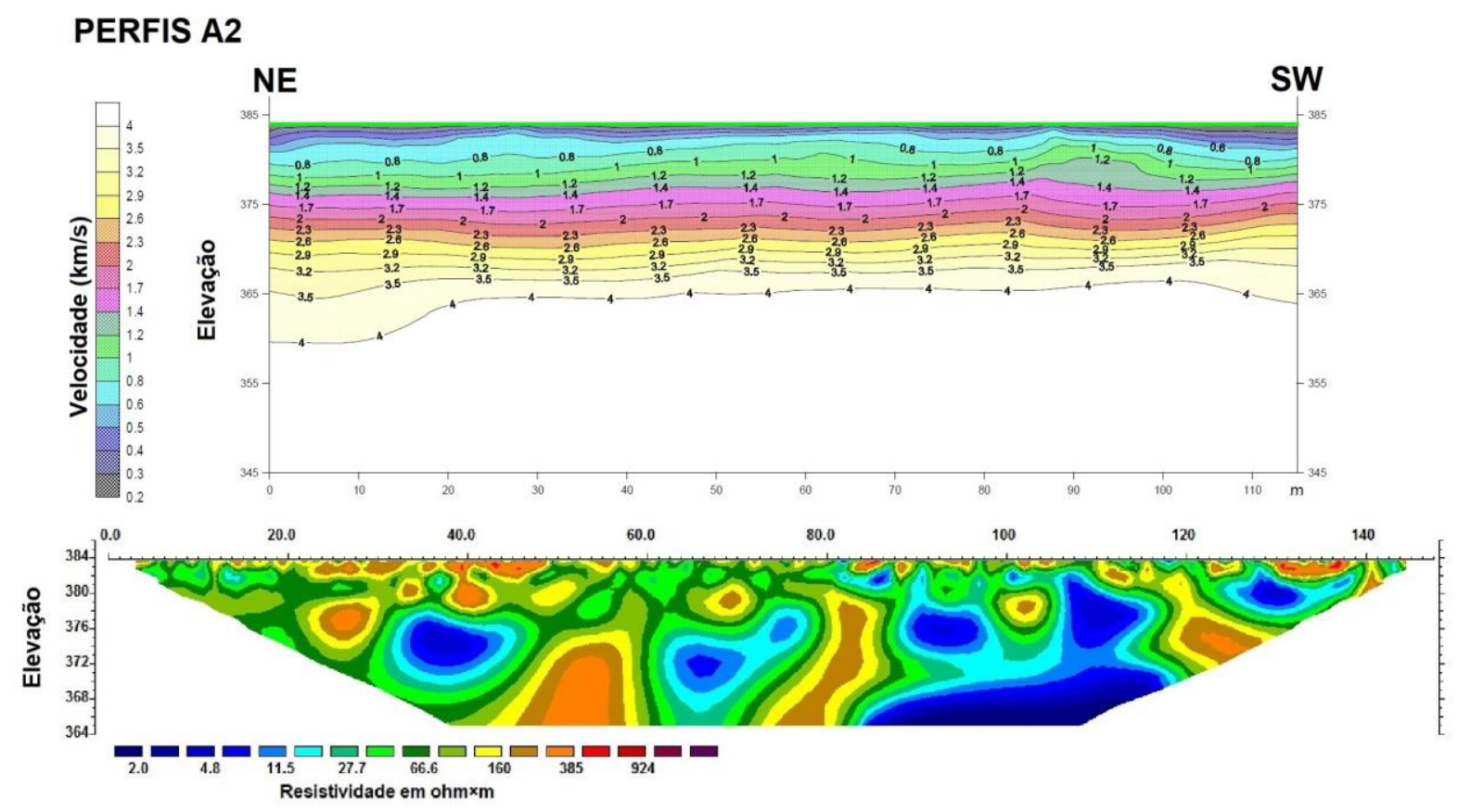

Figura 36: Perfis A2 de sísmica de refração (acima) e caminhamento elétrico (abaixo) da Área A. 


\section{Perfis A3}
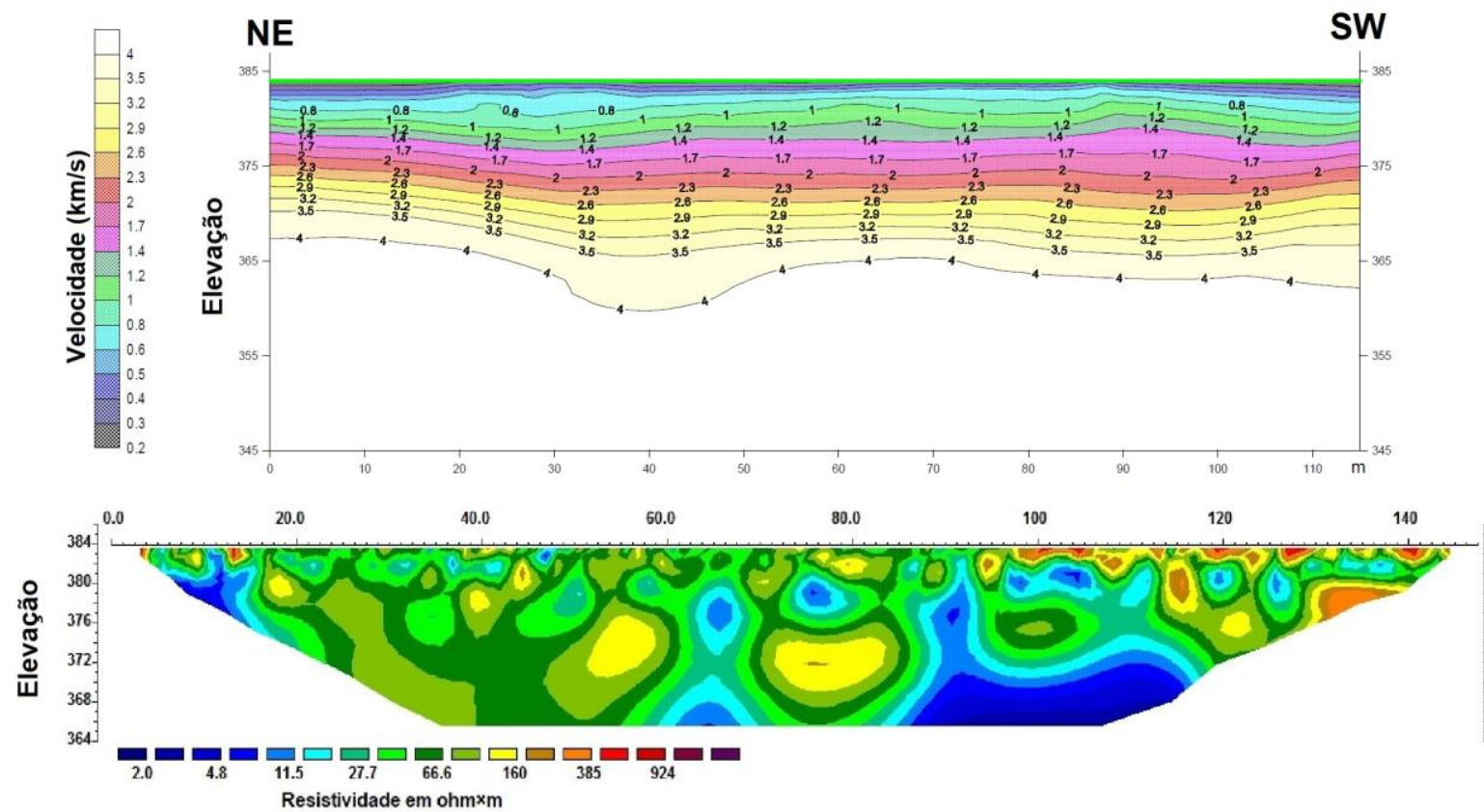

Figura 37: Perfis A3 de sísmica de refração (acima) e caminhamento elétrico (abaixo) da Área A.

No local, a partir de 8 metros de profundidade, são observados corpos com elevada eletrorresistividade em relação ao entorno, possivelmente correspondendo à matacões de rocha menos alterada, com continuidade lateral entre os perfis. De $\mathrm{A} 1$ a $\mathrm{A} 3$ os perfis apresentam valores decrescentes de eletrorresistividade, o que é esperado, uma vez que se aproximam sucessivamente do lineamento sobre o qual está o perfil L1, que apresenta valores baixos de eletrorresistividade. A Figura 388 exibe este padrão através da seção de resistividade horizontal do local entre 9 e $11 \mathrm{~m}$, interpoladas a partir dos perfis de caminhamento elétrico $A 1$ a $A 3$.

Os perfis de sísmica de refração indicam resultados semelhantes àquele do perfil sísmico MASW L1, com a ocorrência do topo da rocha sã de relativa uniformidade entre as cotas 370 e $375 \mathrm{~m}$. Avalia-se, mais uma vez, que a técnica do caminhamento elétrico resultou numa melhor indicação das heterogeneidades geológicas do local. 


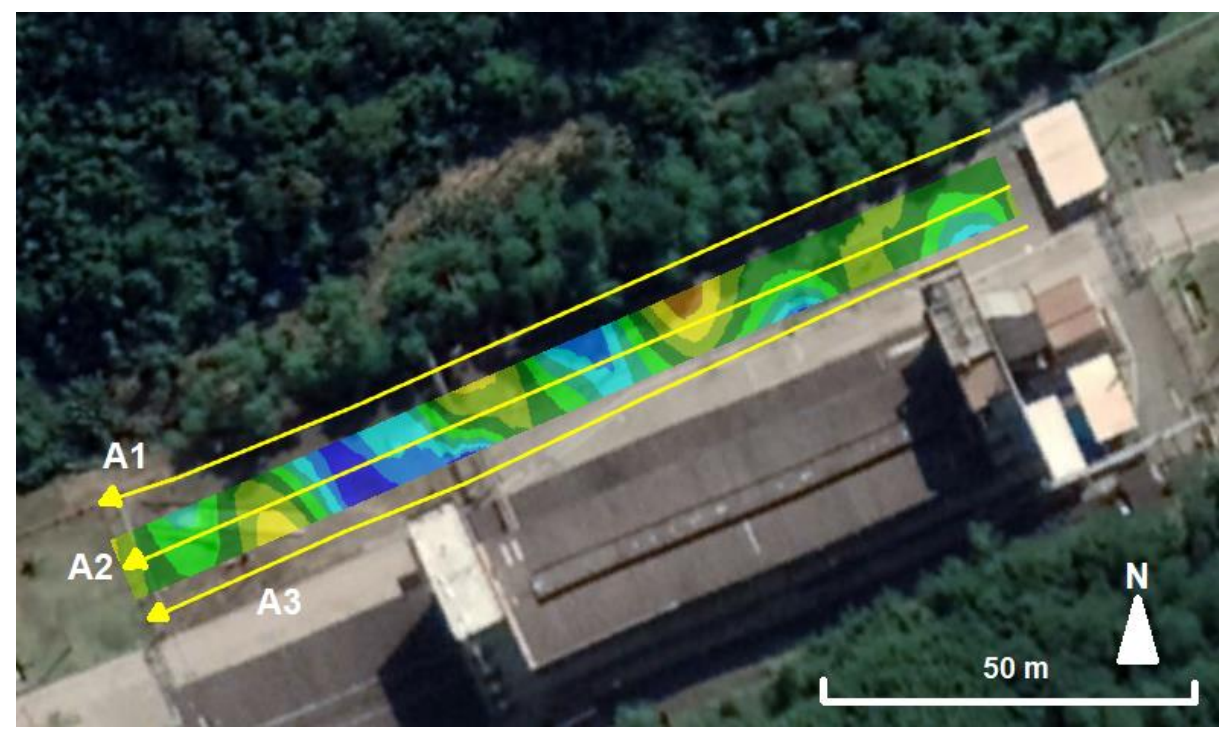

Figura 38: Seção horizontal da área $A$ entre 9 e $11 \mathrm{~m}$, interpoladas a partir dos perfis de caminhamento elétrico A1 a A3.

- Área B

Três perfis paralelos de caminhamento elétrico (identificados como B1, B2 e B3), e outros quatro perfis paralelos de sísmica de refração (identificados como L1B, L2B, L3B e L4B) foram executados na área B, cobrindo uma área aproximada de 90 por 30 metros (Figura 299).

As Figuras 39, 40 e 41 apresentam os resultados comparados dos perfis de sísmica de refração e de caminhamento elétrico. Para ambos os métodos e em todos os perfis, as investigações alcançaram aproximadamente 20 metros de profundidade.

Interpreta-se a presença de um corpo de alta eletrorresistividade e de elevadas velocidades sísmicas, correspondente à rocha sã não fraturada. Esse corpo tem continuidade lateral entre os perfis, e coincide com a continuidade do morrote observado a oeste (Figura 299). Tanto a sísmica de refração como o caminhamento elétrico guardam, portanto, relativa correlação nos resultados. 


\section{Perfis B1}

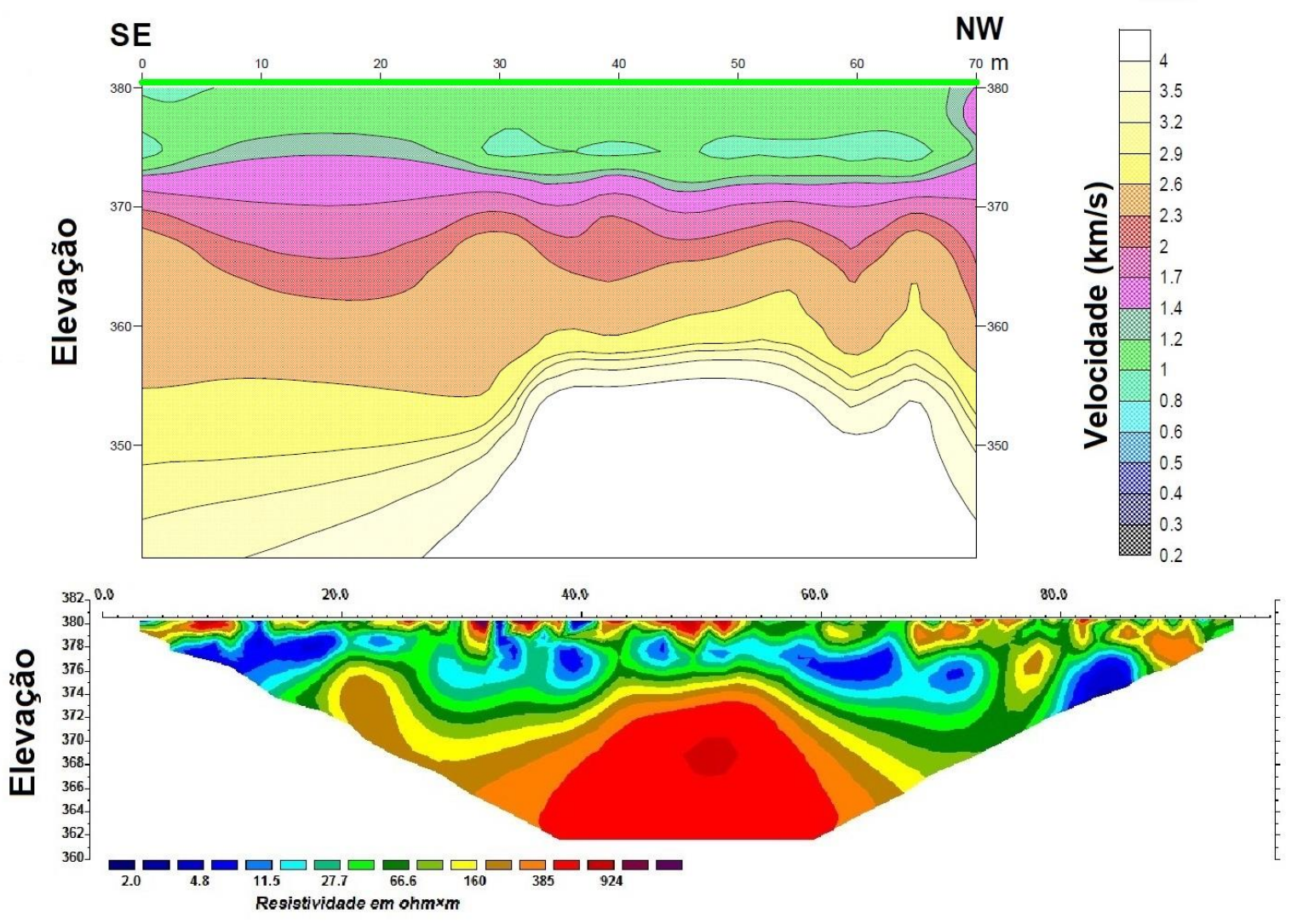

Figura 39: Perfis B1 de sísmica de refração (acima) e caminhamento elétrico (abaixo) da Área B.

\section{Perfis B2}
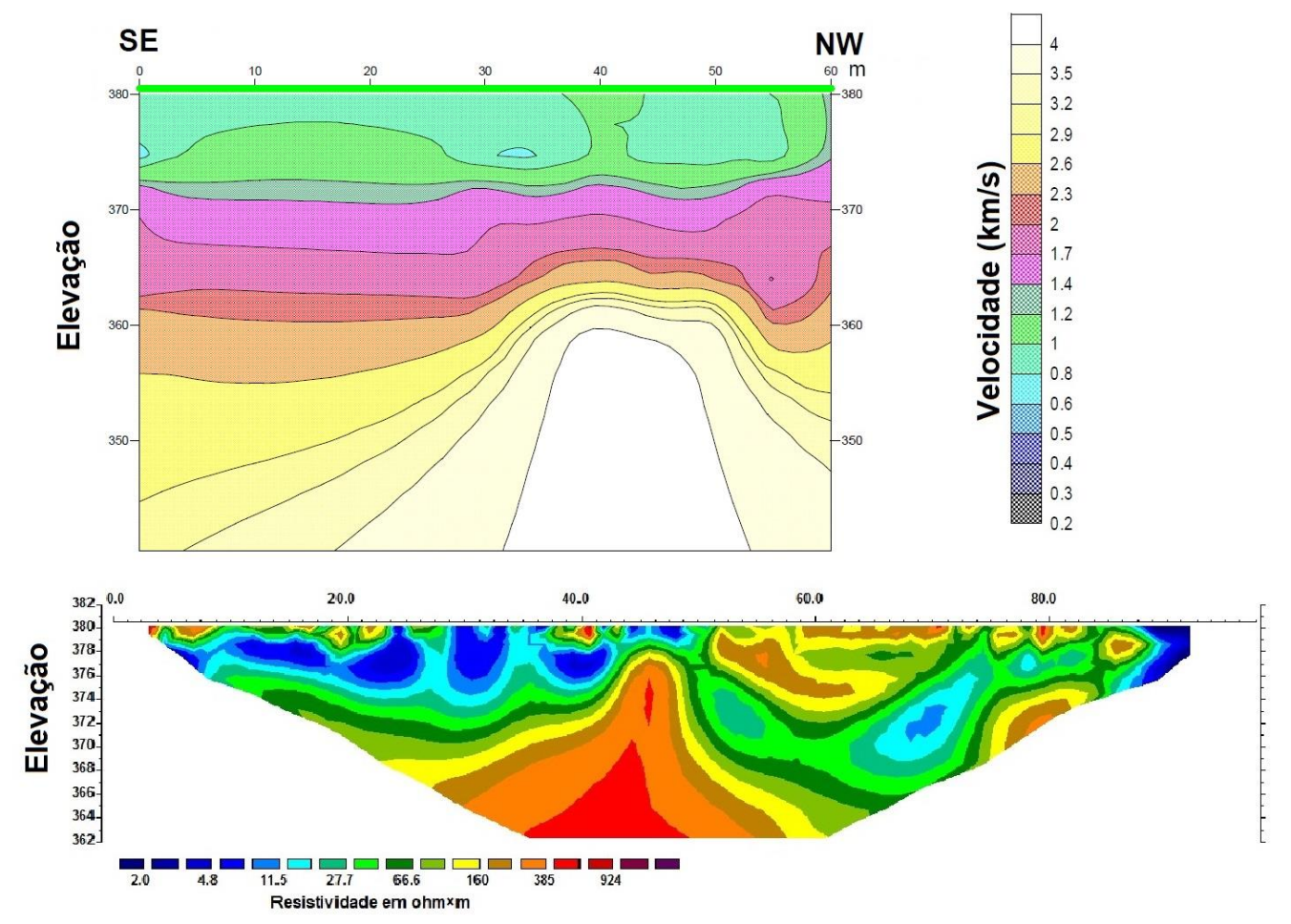

Figura 40: Perfis B2 de sísmica de refração (acima) e caminhamento elétrico (abaixo) da Área B. 


\section{Perfis B3}

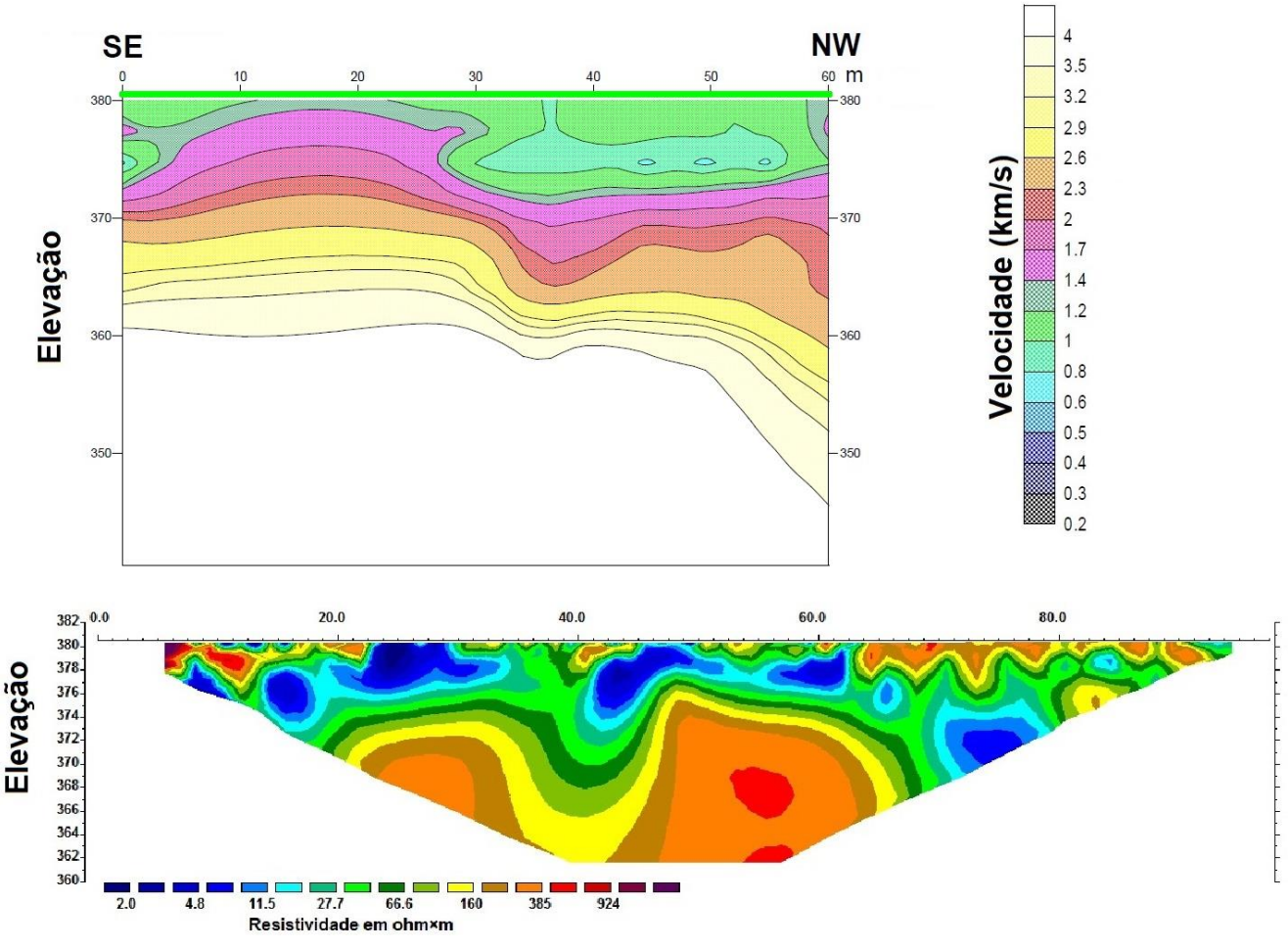

Figura 41: Perfis B3 de sísmica de refração (acima) e caminhamento elétrico (abaixo) da Área B.

A Figura 422 apresenta uma seção de resistividade horizontal do local entre 9 e $11 \mathrm{~m}$, interpoladas a partir dos perfis de caminhamento elétrico B1 a B3. Nota-se que as posições situadas nos extremos, mais próximas dos lineamentos identificados na Figura 299, apresentam resistividade menor, que podem ser indicativo de maior espessamento do manto de intemperismo devido à ocorrência de fraturamento da rocha. 


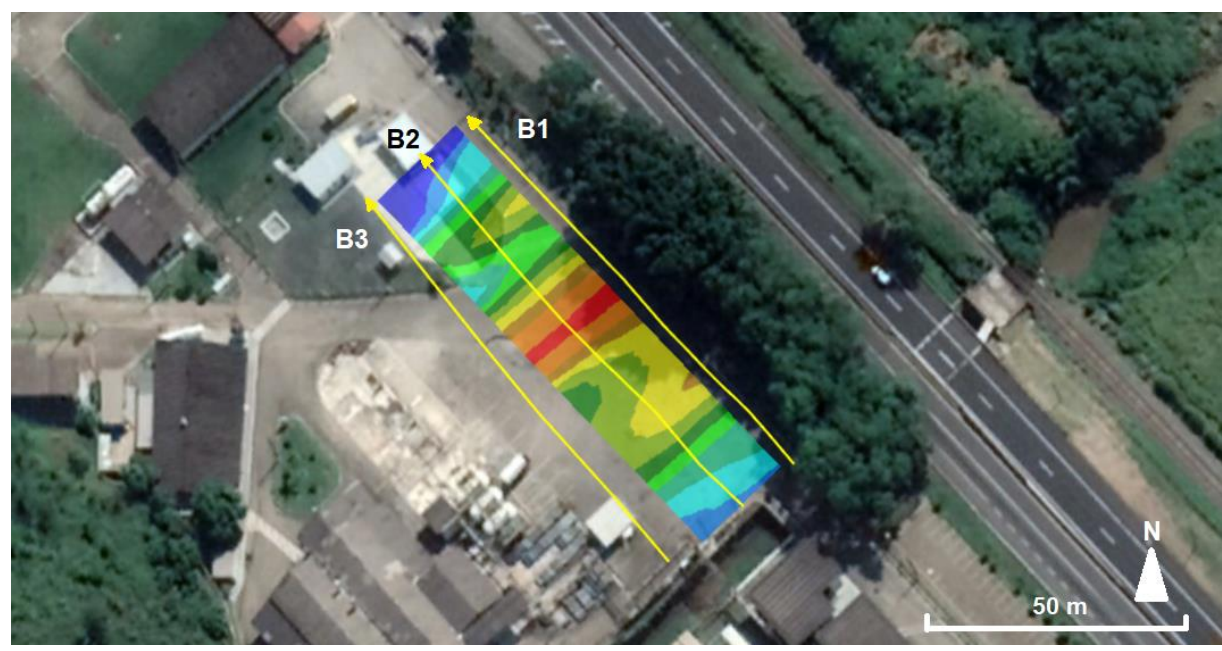

Figura 42: Seção horizontal da área B entre 9 e $11 \mathrm{~m}$, interpoladas a partir dos perfis de caminhamento elétrico B1 a B3.

- Área C

Cinco perfis paralelos de caminhamento elétrico (identificados como $\mathrm{C} 1$ a C5), e outros cinco perfis paralelos de sísmica de refração (identificados como LDC1 a LDC5) foram executados na área C, cobrindo uma área aproximada de 120 por 74 metros (Figura 299). O espaçamento médio entre os perfis é de aproximadamente 18 metros.

As Figuras 43 a 47 apresentam os resultados comparados dos perfis de sísmica de refração e de caminhamento elétrico. Para ambos os métodos e em todos os perfis, as investigações alcançaram aproximadamente 18 metros de profundidade. 


\section{PERFIS C1}
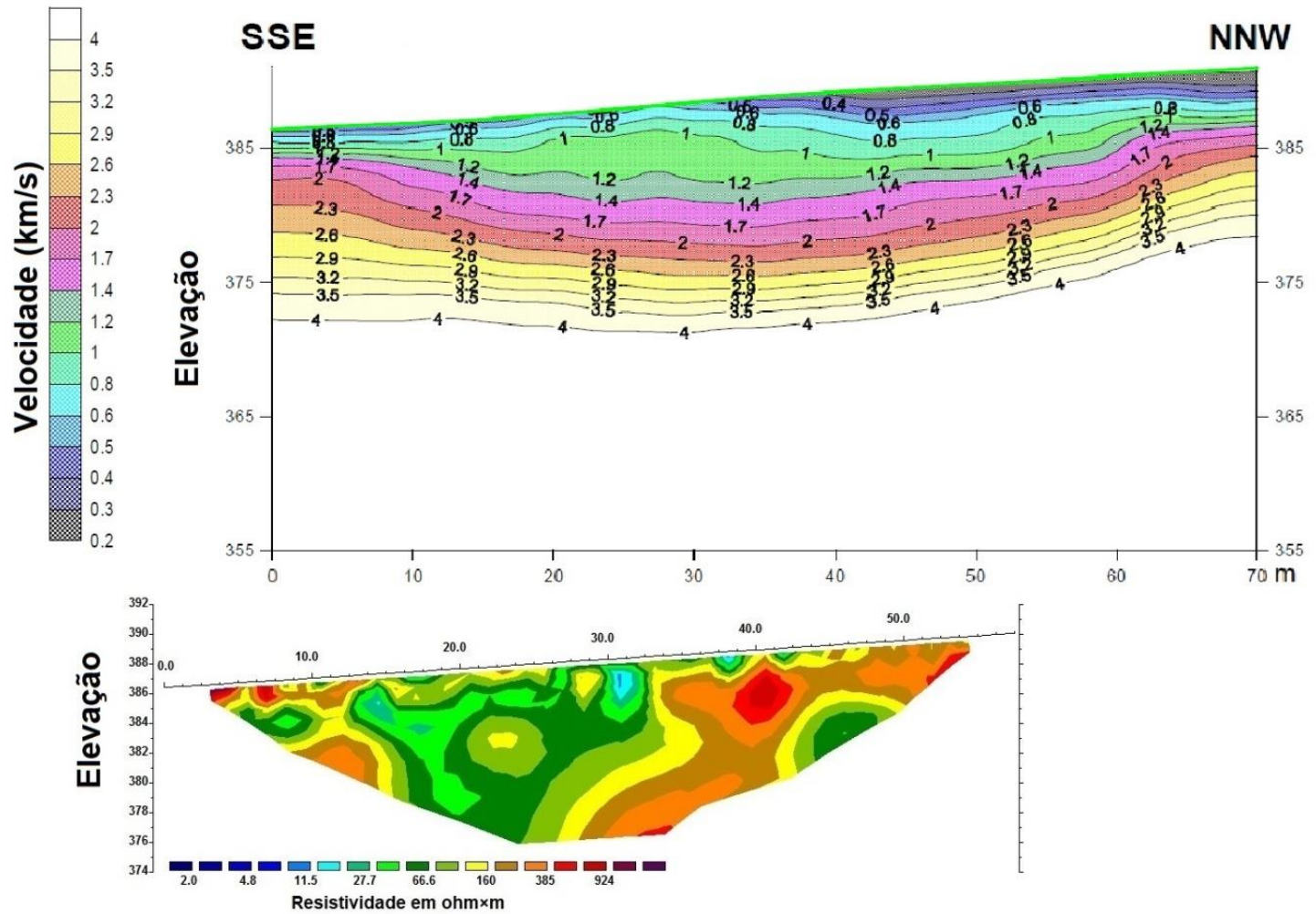

Figura 43: Perfis C1 de sísmica de refração (acima) e caminhamento elétrico (abaixo) da Área C.

\section{PERFIS C2}
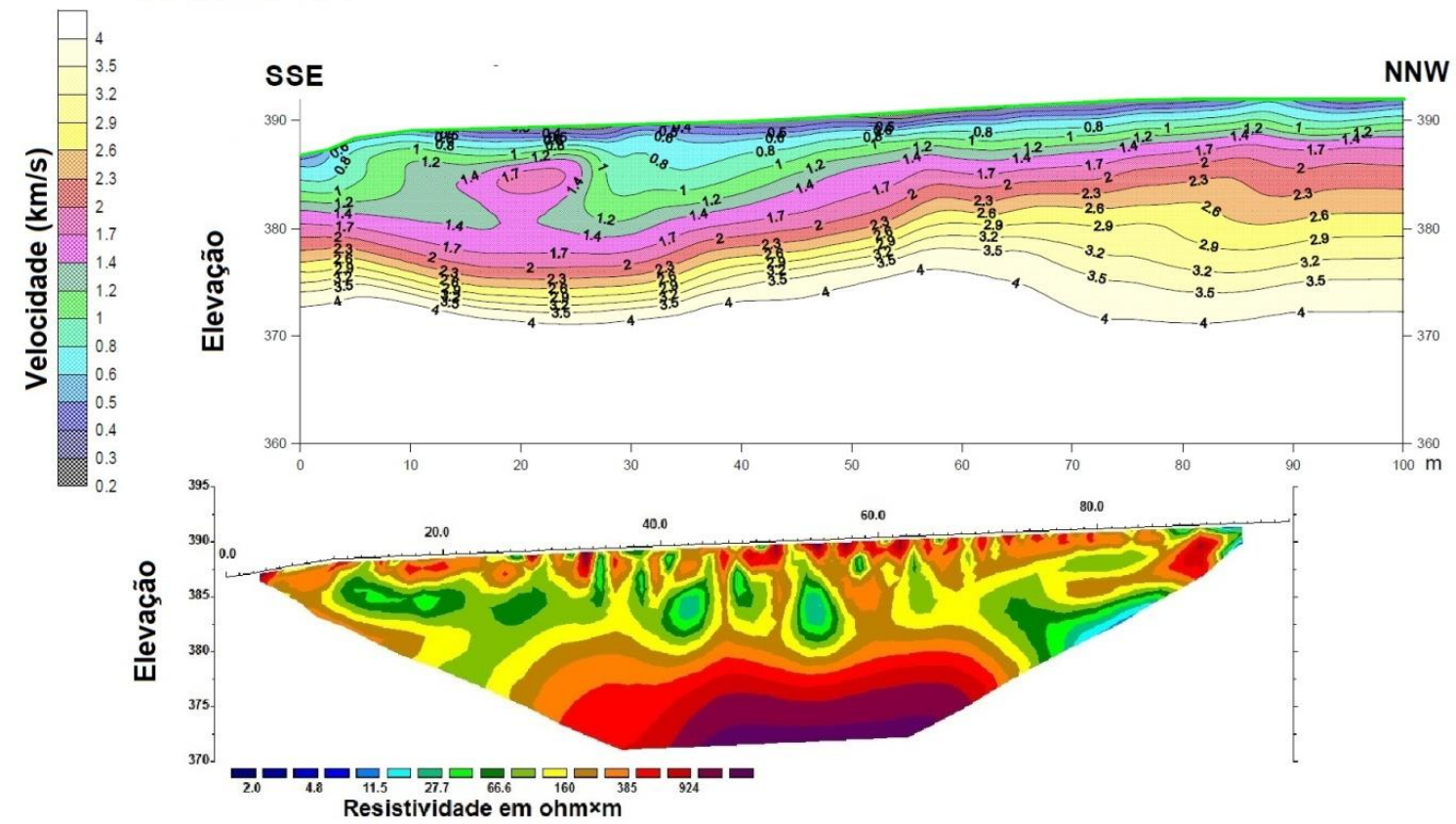

Figura 44: Perfis C2 de sísmica de refração (acima) e caminhamento elétrico (abaixo) da Área C. 


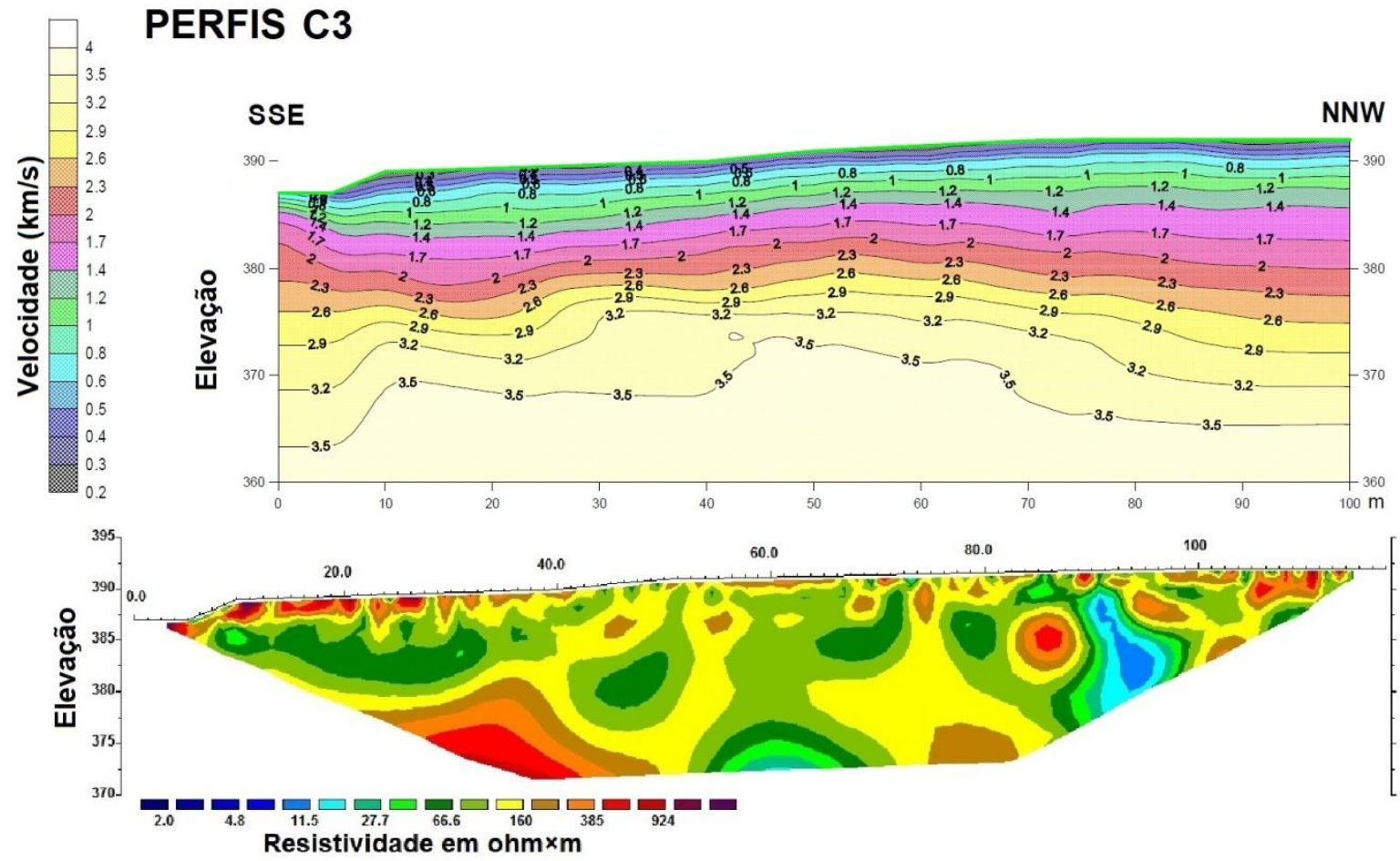

Figura 45: Perfis C3 de sísmica de refração (acima) e caminhamento elétrico (abaixo) da Área C.

\section{PERFIS C4}
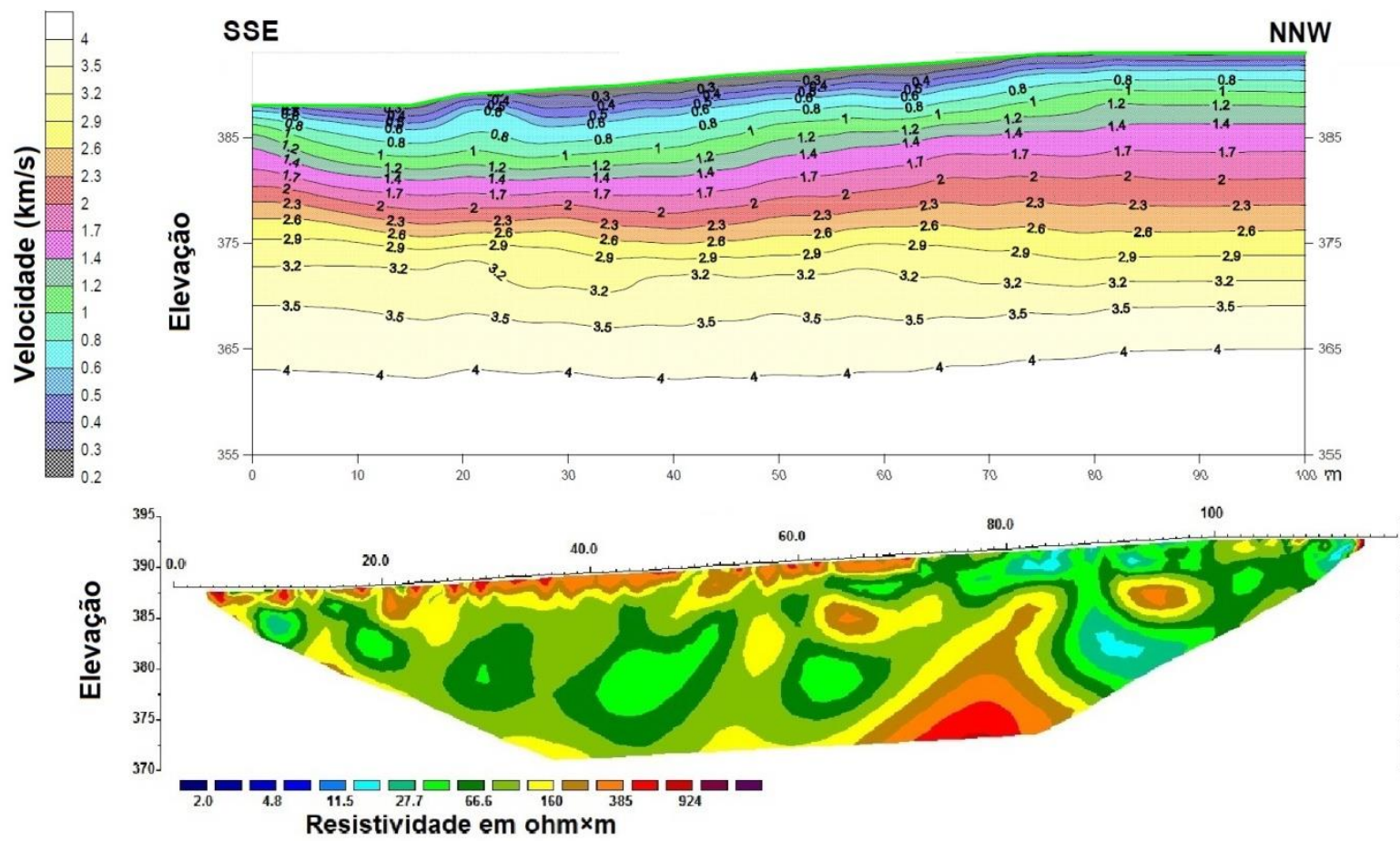

Figura 46: Perfis C4 de sísmica de refração (acima) e caminhamento elétrico (abaixo) da Área C. 


\section{PERFIS C5}

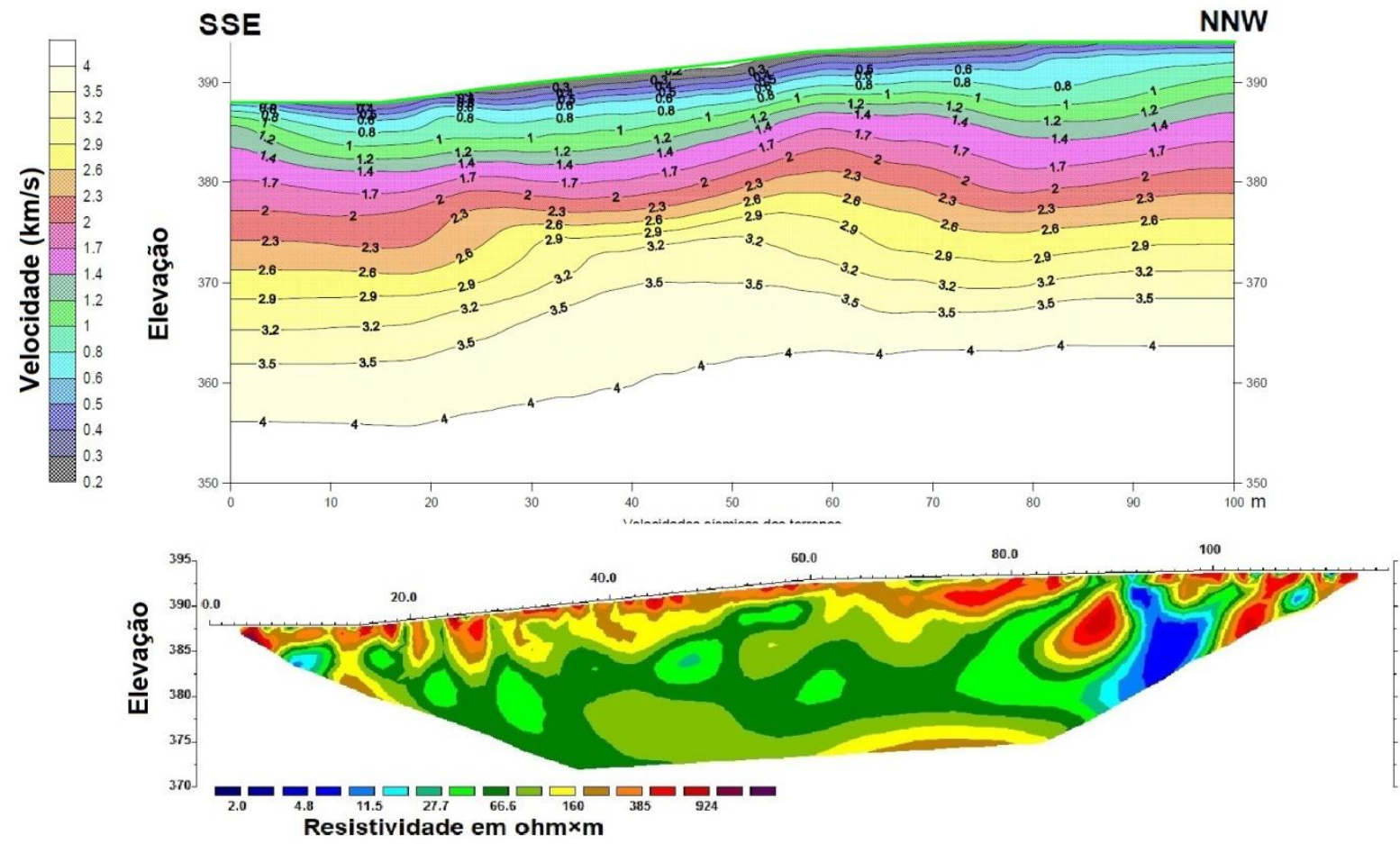

Figura 47: Perfis C5 de sísmica de refração (acima) e caminhamento elétrico (abaixo) refração da Área C.

Os perfis de sísmica de refração na área $C$ parecem identificar o topo rochoso perto da cota 380 metros em toda a área. Os perfis de caminhamento elétrico exibem, com frequência, a presença de corpos resistivos associados a possíveis matacões, a partir de 8 metros de profundidade. Os perfis C3 a C5 mostram a ocorrência de materiais menos resistivos na porção Norte (posição aproximada de 90 metros), que podem estar associados com a maior espessamento do manto de intemperismo.

A Figura 488 apresenta uma seção de resistividade horizontal do local entre 9 e $12 \mathrm{~m}$, interpoladas a partir dos perfis de caminhamento elétrico C1 a C5. Nota-se que predominam corpos de mais elevada resistividade na porção central da figura, denotando a ocorrência da rocha sã. A norte da figura, há uma feição retilínea de material de menor resistividade, refletindo um maior espessamento do manto de intemperismo no local. No extremo sul da área mapeada, há uma tendência para materiais de menor resistividade relativa, o que pode coincidir com a posição do lineamento identificado no local (Figura 299). 


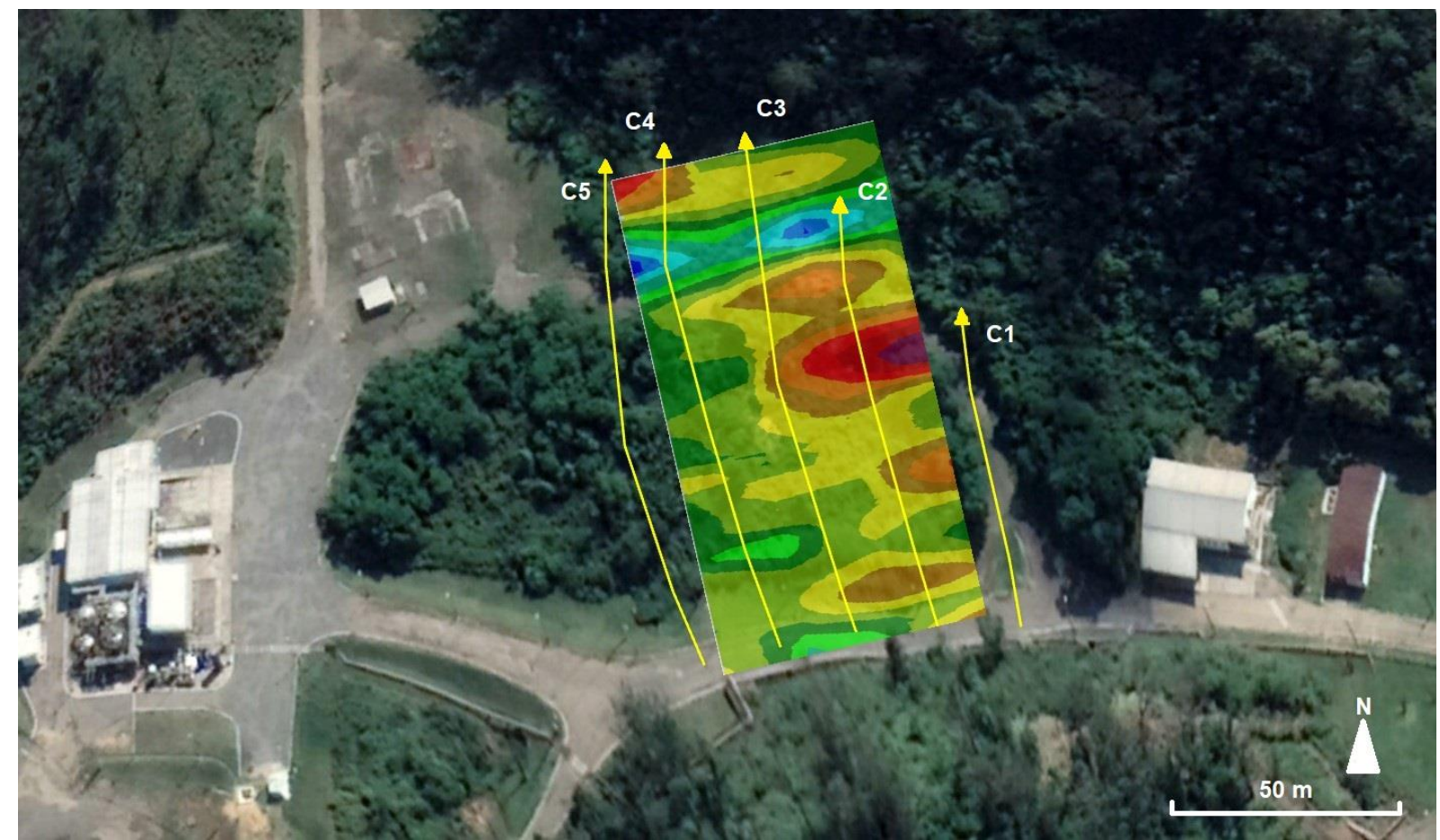

Figura 48: Seção horizontal da área $C$ entre 9 e 12 m, interpoladas a partir dos perfis de caminhamento elétrico C1 a C5.

\subsection{Correlação Entre os Métodos}

Os três métodos utilizados, análise de lineamentos, levantamento estrutural e levantamento geofísico, relacionam-se diretamente, possibilitando a melhor compreensão do meio estudado em diferentes escalas, de regional a local.

Partindo de uma menor escala, a associação entre os lineamentos visualizados nas imagens de satélite (Figuras 18 e 19) e as estruturas verticais medidas na pedreira e na unidade industrial é resumida na Erro! Fonte de referência não encontrada.49. Observa-se que:

(1) as estruturas de baixo ângulo medidas nos afloramentos não aparecem como lineamentos em superfície;

(2) os lineamentos de direção NW (vermelho), que são os mais frequentes nas imagens de satélite, correlacionam-se com as fraturas NW-SE do Grupo 2, observadas tanto na pedreira como na unidade industrial, sendo também as mais abundantes;

(3) lineamentos relativamente frequentes de direção NNW (azul) correlacionam-se com as fraturas de mesma direção medidas nos afloramentos da unidade industrial; 
(4) lineamentos de direção ENE (rosa) correlacionam-se bem com as fraturas de mesma direção medidas na pedreira (Grupo 3);

(5) fraturas ENE-WSW (Grupo 3) não foram observadas nos afloramentos da unidade industrial, embora os lineamentos desta direção tenham sido observados nas imagens de satélite. Provavelmente a ausência dessas fraturas deva-se a direção dos afloramentos visitados, que mascaram sua ocorrência (que de fato devem existir no local);

(6) lineamentos NE (verde), que são relativamente frequentes nas imagens de satélite, não aparecem como fraturas medidas em número significativo nos afloramentos visitados.

\begin{tabular}{|c|c|c|}
\hline $\begin{array}{l}\text { Grupos de } \\
\text { Estruturas }\end{array}$ & Estereogramas de Estruturas & Grupos de Lineamentos \\
\hline Horizontais & Pedreira & $\mathrm{w}$ \\
\hline $\begin{array}{l}\text { Verticais } \\
\text { NW-SE }\end{array}$ & Pedreira Sítio Industrial & NW-SE \\
\hline $\begin{array}{l}\text { Verticais } \\
\text { NNW-SSE }\end{array}$ & $\begin{array}{l}\text { Sítio Industrial } \\
\mathrm{n}=13\end{array}$ & $\overbrace{\mathrm{s}}^{\text {NNw.ssE }}$ \\
\hline $\begin{array}{l}\text { Verticais } \\
\text { ENE-WSW }\end{array}$ & $\mathrm{n=41}$ & 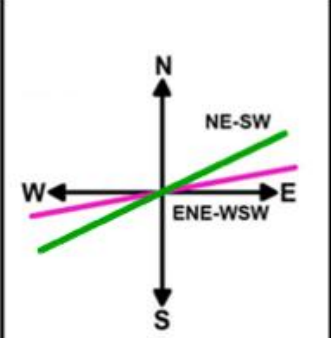 \\
\hline
\end{tabular}

Figura 49: Comparação das direções de lineamentos identificadas com as direções das principais grupos de fraturas medidas nos afloramentos. 
Como relatado e observado, os lineamentos mantêm relação direta com as fraturas e zonas de fraturas observadas em campo, visto que são a expressão geomorfológica superficial dessas estruturas. Fraturas e lineamentos são resultado direto dos esforços tectônicos regionais, e a análise tectônica, em especial a neotectônica, tem por finalidade determinar quais desses grupos de fraturas foram formados ou reativados por eventos tectônicos mais recentes, e que, consequentemente, apresentam maior probabilidade a serem hidraulicamente mais ativos.

Os eventos tectônicos mais recentes, como indicado no estudo de Negrão (2014), são E1, TS, TD e E2, sendo os dois últimos os mais significativos para o presente estudo. O evento E2 (distensão NW-SE) é o mais recente, de idade holocênica a atual; o evento TD (transcorrência dextral E-W) tem idade pleistocênica e foi, dentre todos os eventos citados, o mais intenso na geração e reativação de estruturas da região.

Em seu trabalho, Negrão (2014) relaciona 116 falhas medidas (40\% das estruturas medidas para todos os eventos) ao evento TD (transcorrência dextral E-W), e as principais estruturas associadas a esse evento são aquelas com orientações no intervalo de direções WNW-ESE a NNE-SSW, com destaque à presença de falhas normais, predominantemente com orientação NW-SE. Consequentemente, as fraturas medidas de direções NW-SE (Grupo 2, mais numerosas), lineamentos NW (vermelho), e fraturas medidas de direção NNWSSE (afloramentos da unidade industrial), lineamentos NNW (azul), podem ter gênese associada ao evento TD.

Ao evento E2 (distensão NW-SE), Negrão (2014) associa 92 falhas (32\% das estruturas medidas para todos os eventos), essencialmente falhas normais com direções de NNE-SSW a ENE WSW. Portanto, as estruturas observadas nos afloramentos (e lineamentos) de direção ENE-WSW (Grupo 3), lineamentos ENE (rosa) e NE-SW (pouco observadas na unidade industrial e pedreira), lineamentos NE (verde), podem ter sua gênese associada com o evento E2.

A partir da abordagem de análise tectônica, em relação ao evento TD (transcorrência dextral E-W), as fraturas do Grupo 2, de direção NW-SE, seriam as hidraulicamente mais ativas, ressaltando a maior intensidade desse evento e 0 
maior número de estruturas NW-SE observadas para a região. Em relação ao evento E2 (distensão NW-SE), as fraturas do Grupo 3, ENE-WSW, são as de maior probabilidade à atividade hidráulica, ressaltando que esse é o evento mais recente e que eventos distensivos tem maior importância para a abertura de fraturas.

$\mathrm{Na}$ escala do sítio industrial, é feita a associação de lineamentos traçados às estruturas e às zonas de fraturas em subsuperfície, identificadas pelos métodos geofísicos. A análise das Figuras 18, 19 e 29, nas quais observa-se a disposição dos lineamentos e das linhas geofísicas, em conjunto com os perfis geofísicos discutidos no item 6.3. (Levantamentos geofísicos), permitiu determinar como as principais estruturas e zonas de falhas ocorrem dentro do sítio industrial. A disposição das estruturas soma-se às informações de descontinuidades observadas nas rochas do sítio industrial e à análise neotectônica, permitindo determinar, juntamente com a localização das zonas contaminadas, quais áreas dentro do sítio industrial devem ser foco prioritário de investigação detalhada (Figura 50).

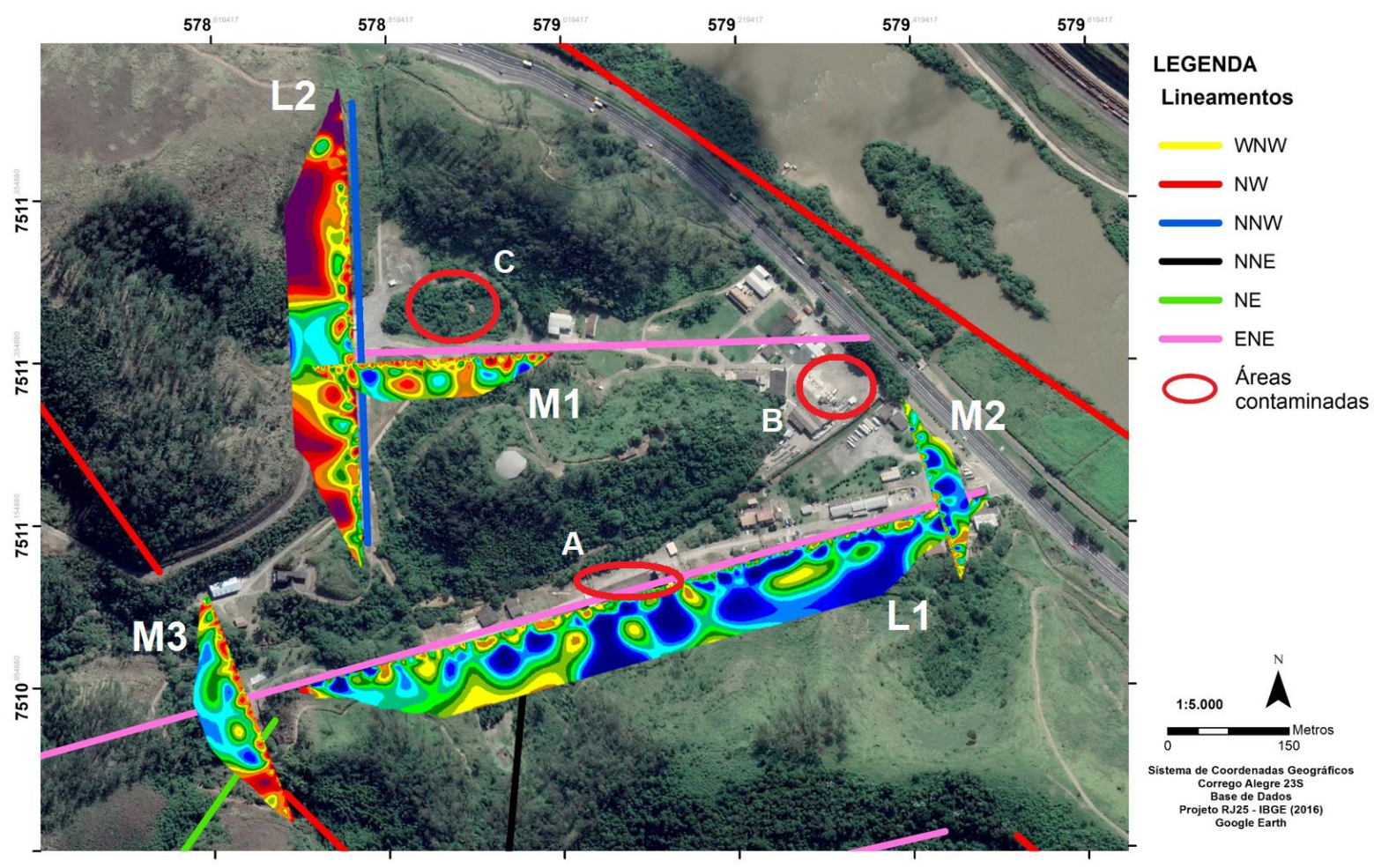

Figura 50: Mapa do sítio industrial com detalhe às zonas contaminadas e às estruturas observadas nessas áreas pelo método de caminhamento elétrico. Os perfis geoelétricos são verticais e estão representados em escala. 


\section{CONCLUSÕES}

De acordo com os objetivos estabelecidos, as técnicas de interpretação de imagens de satélite, de mapeamento geológico-estrutural em afloramentos e técnicas de geofísica (eletrorresistividade e sísmica de refração) foram utilizadas para a caracterização geológica-estrutural das rochas cristalinas e manto de intemperismo da região estudada, onde estão a pedreira e a planta industrial, representando abordagens de caracterização em diferentes escalas, de regional a local.

A análise de lineamentos foi uma técnica de implementação simples e de baixo custo, gerando dados com boa aplicabilidade na correlação com os demais resultados. O levantamento estrutural, e o subsequente tratamento dos dados, foi a etapa que exigiu logística e demanda de tempo e de recursos, e foi a principal atividade no processo de caracterização estrutural, possibilitando a identificação dos grupos de fraturas observados.

Em escala local, as técnicas de geofísica apresentaram ótimos resultados, bem como sua correlação com os lineamentos, possibilitando um melhor entendimento da configuração das estruturas em subsuperfície, imprescindível para balizar medidas futuras de intervenção quanto à contaminação. A correlação entre os diferentes métodos gerou resultados coerentes, e a associação aos eventos neotectônicos possibilitou inferir quais grupos apresentam maior potencial hidráulico para fluxo.

A rocha sã predominante foi identificada como um gnaisse ortoderivado de granulação fina, com porções localizadas de migmatito, associada ao Complexo Juiz de Fora. Os trabalhos de geologia estrutural em afloramentos, associados àqueles das interpretações de lineamentos, permitiram identificar as seguintes principais estruturas na área de estudo:

- Fraturas de baixo ângulo e de diversas direções (Grupo 1), não visíveis nos mapas de lineamentos, de espaçamento métrico irregular, de formato plano a curvo, comprimento médio de 6 metros, mas com algumas unidades muito extensas, e com os maiores indícios de campo para a presença de fluxo de água. Estas fraturas se conectam com todas as demais fraturas existentes. 
- Fraturas NW-SE, de alto ângulo de mergulho (Grupo 2), associadas aos lineamentos mais abundantes observados nas imagens de satélite e às mais frequentes estruturas medidas em afloramentos da pedreira e da unidade industrial. As fraturas têm espaçamento métrico e homogêneo, planas e pouco onduladas, comprimento médio de 8 metros, frequentemente preenchidas por veios de quartzo ou por minerais de origem hidrotermal; algumas, porém preenchidas com óxidos, indicativo de ocorrência de percolação de água. Conexões destas fraturas com outras não foram visíveis nos afloramentos.

- Fraturas ENE-WSW, de alto ângulo de mergulho (Grupo 3), observadas na pedreira com espaçamento homogêneo de 5 metros, planas, comprimento médio de 8 metros, frequentemente preenchidas por veios de quartzo. Conexões destas fraturas com outras não foram visíveis nos afloramentos. Estas fraturas não foram observadas nos afloramentos da unidade industrial, provavelmente por conta da direção dos afloramentos visitados, relativamente paralelos a essas fraturas, que de fato devem existir no local. Essas fraturas apresentam maior probabilidade de serem abertas e ativas à circulação da água subterrânea, por estarem associadas ao evento neotectônico E2, distensivo na direção NW-SE. Lineamentos ENE-WSW foram observados na unidade industrial (incluindo o vale ao longo do córrego), indicativo da presença de fraturas importantes dessa direção no local.

- Fraturas NNW-SSE, de alto ângulo de mergulho, observadas apenas nos afloramentos da unidade industrial e associados com os lineamentos relativamente frequentes de mesma direção, também observados no sítio industrial.

A principal dificuldade do trabalho foi a localização de afloramentos para a amostragem por scanlines. A pedreira apresentou ótimas exposições de rocha, adequadas à técnica, entretanto a disposição espacial das bancadas, que apresentavam orientações muito semelhantes, não é a ideal para sua aplicação. 
A ausência de poços acessíveis na região inviabilizou a amostragem na orientação vertical de fraturas, que poderia ser realizada pelo método de geofísica de poço. Isso resultou na exclusão, pelo método de scanlines, de grande parte das fraturas horizontais, que foram contabilizadas manualmente.

Este trabalho é a etapa inicial de estudo do aquífero fraturado, e no caso de continuidade das investigações por estudos subsequentes, a base metodológica é o método Discrete Fracture Network (DFN; Parker, 2007), aplicado no Brasil por Lojkasek-Lima (2018). O método DFN consiste de uma série de atividades consecutivas para a caracterização detalhada do aquífero fraturado, em especial em áreas sujeitas à contaminação. A etapa intrusiva de investigação é a perfuração de poços com recuperação de testemunhos contínuos de sondagem, com a descrição concomitante de litologias, estruturas e análises químicas e físicas de amostras dos testemunhos. Essa etapa permite o detalhamento das propriedades do aquífero na maior escala possível.

Posteriormente, podem ser realizadas perfilagens geofísicas, como óptica, acústica e de calibre nos poços, além de ensaios com sistemas de obturadores de pressão, fornecendo dados das propriedades hidráulicas de camadas do aquífero e até de fraturas específicas. Após essas etapas, ainda é possível definir zonas de interesse para a instalação de sistemas multinível de alta resolução, que permitem monitorar continuamente cargas hidráulicas e realizar coleta de amostras de água subterrânea em profundidades discretas. 


\section{REFERÊNCIAS BIBLIOGRÁFICAS}

Albuquerque, A. (2001). Análise dos padrões de Fraturamento Neotectônico e a sua possível Aplicação na Avaliação Hidrogeológica da Bacia Sedimentar de Resende (RJ). Anais do Simpósiode Hidrogeologia do Sudeste, XII Encontro Nacional de Perfuradores de Poços, Rio de Janeiro, 165-173 p.

Almeida, J. C. H. D. (2000). Zonas de cisalhamento dúctil de alto grau do Médio Vale do Rio Paraíba do Sul. Unpublished thesis. UNESP - Rio Claro-Brasil, 159p.

Alves, F. M. (2008). Tectônica rúptil aplicada ao estudo de aqüifero em rochas cristalinas fraturadas na região de Cotia, SP. Dissertação (mestrado), Instituto de Geociências, Universidade de São Paulo, São Paulo, 116 p.

Anderson, E. M. (1951). The dynamics of faulting. Oliver and Boyd, Edinburgh, 206 p.

Barton, N., \& Choubey, V. (1977). The shear strength of rock joints in theory and practice. Rock mechanics, 10(1-2), 1-54.

Barton, C. A., Zoback, M. D., \& Moos, D. (1995). Fluid flow along potentially active faults in crystalline rock. Geology, 23(8), 683-686.

Braga, A. C. D. O. (2006). Métodos da eletrorresistividade e polarização induzida aplicados nos estudos da captação e contaminação de águas subterrâneas: uma abordagem metodológica e prática. Tese (livre docência). Universidade Estadual de São Palo, Rio Claro, 123 p.

Briz-Kishore, B. H. (1993). Assessment of yield characteristics of granitic aquifers in South India. Groundwater, 31(6), 921-928.

Caine, J. S., Evans, J. P., \& Forster, C. B. (1996). Fault zone architecture and permeability structure. Geology, 24(11), 1025-1028.

Castro, F. G. (2000). Caracterização hidrogeológica e hidrogeoquímica da bacia sedimentar de Resende - RJ. Dissertação (mestrado), Departamento de Geoliogia, Universidade Federal do Rio de Janeiro, Rio de Janeiro, 130 p.

Chesnaux, R., Allen, D. M., \& Jenni, S. (2009). Regional fracture network permeability using outcrop scale measurements. Engineering Geology, 108(3-4), 259-271.

Degnan, J. R., Clark Jr, S. F., \& Harte, P. T. (2004, January). Integration of geophysics, geologic mapping and water-level monitoring to characterize the hydrogeology of a fractured bedrock site in Berlin, New Hampshire. In Symposium on the Application of Geophysics to Engineering and Environmental Problems 2004 (pp. 759-770). Society of Exploration Geophysicists.

Delgado, I. M., Souza, J. D., Silva, L. C. (2003). Geotectônica do Escudo Atlântico. In: Bizzi, L. A., Schobbenhaus, C., Vidotti, R. M., Gonçalves, J. H. (eds.). Geologia, Tectônica e Recursos Minerais do Brasil: Texto, Mapa e SIG. Brasília: CPRM. 4 CD-ROM. P. 227-334.

Demenico, P. A. \& Schwartz, F. W. (1990). Physical and chemical hydrogeology. Physical and chemical hydrogeology.

Dutta, N. P. (1984). Seismic refraction method to study the foundation rock of a dam. Geophysical Prospecting, 32(6), 1103-1110. 
EEG Ltda., Consultoria Geofísica (2017). Pesquisa geofísica para caracterização do subsolo com aplicação de técnicas sísmicas. Relatório técnico. São Paulo, SP, 23p.

Engelder, T., Fischer, M. P., Gross, M. R. (1993). Fracture Partitioning: failure mode as a function of lithology. Geological Society of America, Annual Meeting, Geological Aspects of Fracture Mechanics (a short course manual), $281 \mathrm{p}$.

Fernandes, A. J. (1997). Tectônica cenozóica na porção média da bacia do rio Piracicaba e sua aplicação a hidrogeologia de meios fraturados. Tese (doutorado), Instituto de Geociências, Universidade de São Paulo, São Paulo, 244 p.

Fernandes, A. J. (2008). Aqüíferos fraturados: uma revisão dos condicionantes geológicos e dos métodos de investigação. Revista do Instituto Geológico, 29(1-2), 49-72.

Fernandes, A., \& Rudolph, D. L. (2001). The influence of Cenozoic tectonics on the groundwater-production capacity of fractured zones: a case study in Sao Paulo, Brazil. Hydrogeology Journal, 9(2), 151-167.

Fernandes, A. J., Perrotta, M. M., Salvador, E. D., Azevedo, S. G., Gimenez Filho, A., \& Paulon, N. (2007). Potencial dos aquíferos fraturados do estado de São Paulo: condicionantes geológicos. Águas Subterrâneas, 21(1).

Fernandes, A. J. \& Rouleau, A. (2008). Simulação de deslocamentos em fraturas em basaltos da Formação Serra Geral (Ribeirão Preto, SP) e implicações para a sua transmissividade. Águas Subterrâneas, 15, Suplemento.

Fernandes, A. J.; Maldaner, C. H.; Rouleau, A. (2011) Análise das fraturas nos basaltos de Ribeirão Preto, SP: aplicação à elaboração de modelo hidrogeológico conceitual. Revista Geologia USP. Série Cientîfica.

Fernandes, A. J., Negri, F., Sobrinho, J. A., \& Varnier, C. (2012). Análise de fraturas dos basaltos do Aquífero Serra Geral e o potencial de recarga regional do Sistema Aquífero Guarani. Boletín Geológico y Minero, 123(3), 325-339.

Ferrill, D. A., Winterle, J., Wittmeyer, G., Sims, D., Colton, S., Armstrong, A., \& Morris, A. P. (1999). Stressed rock strains groundwater at Yucca Mountain, Nevada. GSA Today, 9(5), 1-8.

Fiume, B. (2013). Geologia de detalhe para elaboração de modelo conceitual de circulação de água subterrânea: estudo de caso em Jurubatuba, SP. Dissertação (mestrado). Instituto de Geociências, Universidade de São Paulo, São Paulo, 165 p.

Francese, R., Mazzarini, F., Bistacchi, A., Morelli, G., Pasquarè, G., Praticelli, N. \& Zaja, A. (2009). A structural and geophysical approach to the study of fractured aquifers in the Scansano-Magliano in Toscana Ridge, southern Tuscany, Italy. Hydrogeology journal, 17(5), 1233-1246.

Gale, J., \& Rouleau, A. (1983). Characterizing and interpreting the geometry, permeability and porosity of fractures for repository evaluation. In International Symposium on Field Measurements in Geomechanics, Zurich, Proceedings (pp. 1343-1369).

Guerra, K. J. (2010). Aplicação de método geofísico em estudo hidrogeológico no município de Nova Lima - MG: caracterização de aquíferos em área urbana. Dissertação (mestrado), Instituto de Geociências, Universidade Federal de Minas Gerais, Belo Horizonte, $116 \mathrm{p}$. 
Hatherly, P. J., \& Neville, M. J. (1986). Experience with the generalized reciprocal method of seismic refraction interpretation for shallow engineering site investigation. Geophysics, 51(2), 255-265.

Heilbron, M. D. C. P. L. (1993). Evolução tectono-metamórfica da seção Bom Jardim de Minas (MG)-Barra do Pirai (RJ): setor central da faixa Ribeira. Tese (doutorado), Instituto de Geociências, Universidade de São Paulo, São Paulo, 268 p.

Heilbron, M.C.L. (1995). O Segmento Central da Faixa Ribeira: Síntese Geológica e Ensaio de Evolução Geotectônica. Tese (livre-docência), Departamento de Geologia, Universidade Estadual do Rio De Janeiro, Rio de janeiro, 110 p.

Heilbron, M., Valeriano, C. M., Almeida, J. C. H., \& Tupinambá, M. (1991). A Megassinformal do Paraíba do Sul e sua implicação na compartimentação tectônica do setor central da Faixa Ribeira. SBG, Simp Geol Sud, 2, 519-527.

Heilbron, M., Mohriak, W. U., Valeriano, C. M., Milani, E. J., Almeida, J., \& Tupinambá, M. (2000). From collision to extension: the roots of the southeastern continental margin of Brazil. Atlantic rifts and continental margins, 1-32.

Heilbron, M. et al. (2003). Mapa Tectônico da Faixa Ribeira Central. TEKTOS, Grupo de Pesquisa em Geotectônica da UERJ (inédito).

Heilbron. M., Pedrosa-Soares, A.C., Campos Neto, M.C., Silva, L.C., Trouw, R.A.J., Janasi, V.A. (2004). Província Mantiqueira. In: V. Mantesso-Neto, A. Bartorelli, C. Dal Ré Carneiro \& B.B. Brito Neves (orgs.) Geologia do Continente Sul-Americano - Evolução da Obra de Fernando Flávio Marques de Almeida. Beca, p. 203-235.

Instituto Brasileiro de Geografia e Estatística - IBGE / Diretoria de Geociências - DGC / Coordenação de Cartografia - CCAR. Projeto Rio de Janeiro 1:25.000 (RJ-25). Disponível em: https://www.ibge.gov.br/geociencias-novoportal/modelos-digitaisde-superficie/modelos-digitais-de-superficie/10856-mde-modelo-digital-deelevacao.html?\&t=downloads. Acessado em 15 de agosto de 2017 (modelos digitais de elevação utilizados: 27432no; 27431ne; 27134so; 27133se.

Keller, G. V., \& Frischknecht, F. C. (1966). Electrical methods in geophysical prospecting. Pergamon Press, Inc.

Lawn, B., \& Wilshaw, R. (1975). Indentation fracture: principles and applications. Journal of materials science, 10(6), 1049-1081.

Machado, N., Valladares, C., Heilbron, M., \& Valeriano, C. (1996). U-Pb geochronology of the central Ribeira belt (Brazil) and implications for the evolution of the Brazilian Orogeny. Precambrian Research, 79(3-4), 347-361.

Madrucci, V., Taioli, F., \& Araújo, C. C. D. (2005). Análise integrada de dados de sensoriamento remoto, geologia e geofísica no estudo de aqüífero fraturado, Lindóia-SP. Revista Brasileira de Geofísica, 23(4), 437-451.

Maillet, R. (1947). The fundamental equations of electrical prospecting. Geophysics, 12(4), 529-556.

Marins, G.M.M. (2000). Petrologia dos Anfibolitos do Domínio Juiz de Fora e da Klippe Paraíba do Sul, Setor Central da Faixa Ribeira. Dissertação de Mestrado, FGEL/UERJ, 135 p. Inédita. 
Morin, R. H., \& Savage, W. Z. (2003). Effects of crustal stresses on fluid transport in fractured rock: case studies from northeastern and southwestern USA. Hydrogeology Journal, 11(1), 100-112.

Negrão, A. P. (2014). Evolução tectonossedimentar e deformação rúptil cenozoica da região da bacia sedimentar de Volta Redonda (Segmento Central do Rifte Continental do Sudeste do Brasil, RJ). Tese (doutorado). Instituto de Geociências, Universidade Federal do Rio de Janeiro, Rio de Janeiro, 248 p.

Neves, F. A. (1998). Estudo da depressão circular de Colônia, SP, pelo método sísmico. Revista Brasileira de Geociências, 28, 3-10.

Novakowski, K. (1995). Groundwater flow in fractured rocks. Waterloo Centre for Ground Water Research, Course Notes, $46 \mathrm{p}$.

Odling, N. E. (1997). Scaling and connectivity of joint systems in sandstones from western Norway. Journal of Structural Geology, 19(10), 1257-1271.

Odling, N. E., Gillespie, P., Bourgine, B., Castaing, C., Chiles, J. P., Christensen, N. P. \& Trice, R. (1999). Variations in fracture system geometry and their implications for fluid flow in fractures hydrocarbon reservoirs. Petroleum Geoscience, 5(4), 373384.

Orellana, E. (1972). Prospección geoelétrica en corriente continua. Madrid: Paraninfo. $523 \mathrm{p}$.

Park, C. B., Miller, R. D., Xia, J. (1999). Multichannel analysis of surface waves. Geophysics, 64(3), 800-808.

Pereira, R. M. (2001). Caracterização geocronológica, geoquímica, geofísica e metalogênica de alguns plutonitos graníticos da região do médio rio Paraíba do Sul e alto Rio Grande, segmento central da Faixa Ribeira. Tese (doutorado). Instituto de Geociências, Universidade Federal do Rio de Janeiro, Rio de Janeiro, 214 p.

Pino, S. (2012). Structural hydrogeology in the Kenogami uplands, Quebec, Canada. In Masters Abstracts International (Vol. 51, No. 03).

Priest, S.D. (1993). Discontinuity analysis for rock engineering. Chapman \& Hall, London, $473 \mathrm{p}$.

PRONAGEO UERJ/CPRM. 2007. Folhas: Volta Redonda (SF-23-Z-A-V), CPRM (2007); Barra do Piraí (SF-23-Z-A-III), CPRM (2007); Santa Rita do Jacutinga (SF23-Z-A-II), CPRM (2007). Mapas Geológicos.

Reynolds, J. M. (2011). An introduction to applied and environmental geophysics. John Wiley \& Sons. Ltd, Chichester, $796 \mathrm{p}$

Riccomini, C. (1989). Rift Continental do Sudeste do Brasil. São Paulo. Tese (doutorado). Instituto de Geociências, Universidade de São Paulo, São Paulo, 256 p.

Riccomini, C., Sant'Anna, L. G., \& Ferrari, A. L. (2004). Evolução geológica do rift continental do sudeste do Brasil. Geologia do continente Sul-Americano: evolução da obra de Fernando Flávio Marques de Almeida, 383-405.

Robinson, D. A., Binley, A., Crook, N., Day-Lewis, F. D., Ferré, T. P. A., Grauch, V. J. S., \& Nyquist, J. (2008). Advancing process-based watershed hydrological research using near-surface geophysics: A vision for, and review of, electrical and magnetic geophysical methods. Hydrological Processes, 22(18), 3604-3635. 
Rouleau, A., \& Gale, J. E. (1985, December). Statistical characterization of the fracture system in the Stripa granite, Sweden. In International Journal of Rock Mechanics and Mining Sciences \& Geomechanics Abstracts (Vol. 22, No. 6, pp. 353-367). Pergamon.

Sanson, M. S. R. (2006). Sistemas deposicionais aluviais e tectônica cenozóica na região de Volta Redonda (RJ)-Rift Continental do Sudeste do Brasil. Dissertação (mestrado). Instituto de Geociências, Universidade Federal do Rio de Janeiro, Rio de Janeiro, $151 \mathrm{p}$.

Snow, D. T. (1968). Rock fracture spacings, openings, and porosities. Journal of Soil Mechanics \& Foundations Division, 94: 73-91.

Surrette, M., Allen, D. M. \& Journeay, M. (2008). Regional evaluation of hydraulic properties in variably fractured rock using a hydrostructural domain approach. Hydrogeology Journal, 16(1), 11.

Telford, W. M., Telford, W. M., Geldart, L. P., \& Sheriff, R. E. (1990). Applied geophysics (Vol. 1). Cambridge university press, $770 \mathrm{p}$.

Terzaghi, R. D. (1965). Sources of error in joint surveys. Geotechnique, 15(3), 287304.

Larsson (1984). Ground water in hard rocks. Paris, UNESCO, Studies and Reports in Hydrogeology 33, $228 \mathrm{p}$.

Vialon, P.; Ruhland, M.; Grolier, J. (1976). Éléments de tectonique analytique. Masson, Paris, 118p.

Wahnfried, I. D. (2010). Modelo conceitual de fluxo do Aquitarde Serra Geral e do Sistema Aquífero Guarani na região de Ribeirão Preto, SP (Doctoral dissertation, Universidade de São Paulo). 


\section{ANEXO I}

(FICHA PARA COLETA DE DADOS DE CAMPO COM SCANLINES) 


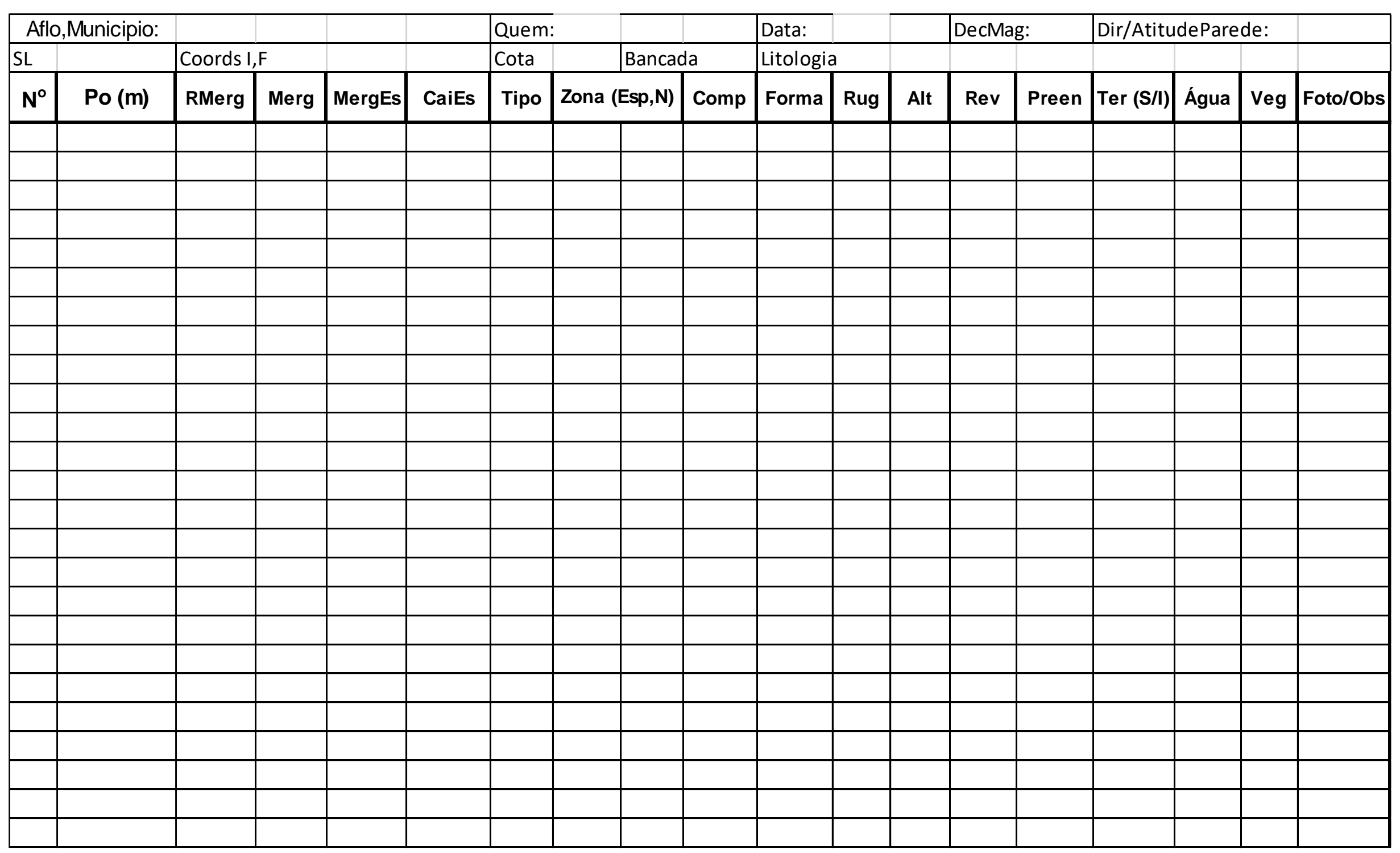




\begin{tabular}{|c|c|c|c|}
\hline \multicolumn{4}{|c|}{ Convenções para preenchimento da tabela } \\
\hline mero sequencial da fratura & número de identificacão & \multirow{8}{*}{$\begin{array}{l}\text { Revestimento } \\
\text { (Rev), é uma } \\
\text { película }\end{array}$} & Fe - filme escuro \\
\hline Foto & número da foto & & Fv - filme esverdeado \\
\hline \multirow{2}{*}{ Posição (Po) } & posição em $\mathrm{m}$ de onde a & & $\mathrm{Fb}$ - filme branco \\
\hline & estrutura cruza a scanline & & Pc - Película carbonática \\
\hline Rumo do Mergulho (RM) & direção do mergulho da fratura & & Su - Sulfetos \\
\hline Mergulho (M) & mergulho plano de fratura & & Ox - óxidos \\
\hline Mergulho da estria (EsM) & mergulho de estria & & \\
\hline Caimento da estria (EsC) & orientação da estria & & \\
\hline \multirow{6}{*}{ Tipo } & $\mathrm{Ft}=$ Fratura simples & \multirow{9}{*}{$\begin{array}{l}\text { Preenchimento } \\
\text { (Preen) }\end{array}$} & esperrusa em $\mathbf{~ c m}$, entre parenteses \\
\hline & $\mathrm{Fa}=$ Falha & & Su - Sulfetos \\
\hline & ZFt = Zona de Fratura & & fi - silte ou argila \\
\hline & ZFa = Zona de Falha & & ca - carbonato \\
\hline & & & ox - óxido \\
\hline & & & qz - quartzo \\
\hline \multirow{3}{*}{ Zona de Fraturas } & & & ar - areia \\
\hline & Esp $=$ espessura em $\mathbf{m}$ & & di - dique \\
\hline & $\mathrm{N}=$ número de fraturas & & ve - veio \\
\hline Comnrimente ( $\mathrm{C}$ ) & tamanho em $\mathrm{m}$ da fratura & \multirow{6}{*}{$\begin{array}{c}\text { Terminação (Ter) } \\
\text { S = superior } \\
\text { I = inferior }\end{array}$} & Ce - cega (termina em rocha) \\
\hline ) & dentro da scanline & & Cf - confinado (termina em outra fratura) \\
\hline \multirow{3}{*}{ Forma (Fr) } & $P=$ Plana & & $\mathrm{Cr}$ - cruzando outra fratura \\
\hline & $\mathrm{O}=$ Ondulada, $\mathrm{C}=$ Curva & & Fp - Fora da Parede \\
\hline & $\mathrm{I}=\mathrm{Irregular}$ & & Ho - Fratura horizontal \\
\hline \multirow{2}{*}{ Rugosidade (Reg) } & Escala numérica de 1 a 20 & & Ac - Acamamento ou bandamento \\
\hline & Palmstron 1995 & \multirow{4}{*}{ Água } & S - Seco \\
\hline \multirow{5}{*}{ 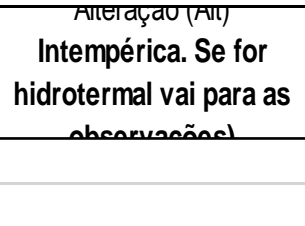 } & Ds - Descoloramento & & U - Úmido \\
\hline & Ro = alteração da rocha, $\mathrm{cm}$ & & G- Gotejando \\
\hline & $\operatorname{Re}=$ alteração do revestimento & & V - Vertência constante \\
\hline & & Vegetação (Veg) & assinalar com X se estiver presente \\
\hline & & Foto/Obs & Número da foto e/ou com Obs, anotada no verso da pé \\
\hline \multirow{7}{*}{ Observações } & \multicolumn{3}{|c|}{ padrões de fraturas: en echelon, em flor, conjugados, anastomosamento das fraturas (ZF), terminação ramificada (Y) } \\
\hline & \multicolumn{3}{|l|}{ abertura natural } \\
\hline & \multicolumn{3}{|l|}{ se foi coletada amostra } \\
\hline & \multicolumn{3}{|c|}{$\begin{array}{l}\text { anotar se há croqui (caso haja indicadores de movimento, desenhar indicando sentido e descrever, de forma completa } \\
\text { a feição; orientar o plano desenhado e colocar escala) }\end{array}$} \\
\hline & \multicolumn{3}{|c|}{ sempre observar estruturas importantes que estejam fora da scanline } \\
\hline & \multicolumn{3}{|c|}{ sentido de movimento qdo houver Ls (D-dextral, S-sinistral, N-normal, I-inverso) } \\
\hline & \multicolumn{3}{|c|}{ outras medidas estruturais: foliação, eixo de dobra, plano axial } \\
\hline
\end{tabular}

